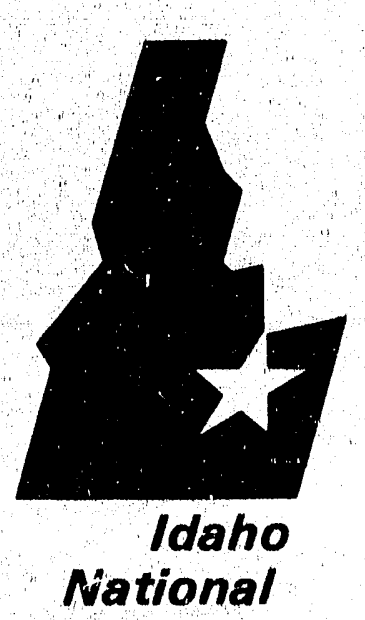

Engineering

Laboratory.

Managed by the U.S.

Department

of Energy
EGG-WTD-9911

February 1992

APR 271992

Melter Development Needs Assessment for RWMC Buried Wastes
A. D. Donaldson
R. J. Carpened?
G. L. Anderson

$\operatorname{Cogsc}_{1 \mathrm{daho}}$

Work performed under

DOE Contract

No. DE-AC,07-761001570 
This document contains new concepts or the author(s) interpretation of new calculations and/or measureinents; accordingly, EG\&G Idaho, Inc. is required by the United States Government to include the following disclaimer:

\section{DISCLAIMER}

This report was prepared as an account of work sponsored by an agency of the United States Government. Neither the United States Government nor any agency thereof, nor any of their employees, makes any warranty, express or implied, or assumes any legal liability or responsibility for the accuracy, completeness, or usefulness of any information, apparatus, product or process disclosed, or represents that its use would not infringe privately owned rights. References herein to any specific commercial product, process, or service by trade name, trademark, manufacturer, or otherwise, does not necessarily constitute or imply its endorsement, recommendation, or favoring by the United States Government or any agency thereot. The views and opinions of authors expressed herein do not necessarily state or reflect those of the United States Government or any agency thereof. 


\title{
Melter Development Needs Assessment for RWMC Buried Wastes
}

\author{
A. D. Donaldson \\ R. J. Carpenedo \\ G. L. Anderson \\ Published February 1992 \\ Idaho National Engineering Laboratory \\ EG\&G Idaho, Inc. \\ Idaho Falls, ID 83415
}

Prepared for the

U.S. Department of Energy

Office of Environmental Restoration and Waste Management

Under DOE Idaho Field Office

Contract No. DE-AC07-76ID01570 
Melter Development Needs Assessment

Prepared by:

Ad) Durcelderer

A. D. Donaldson

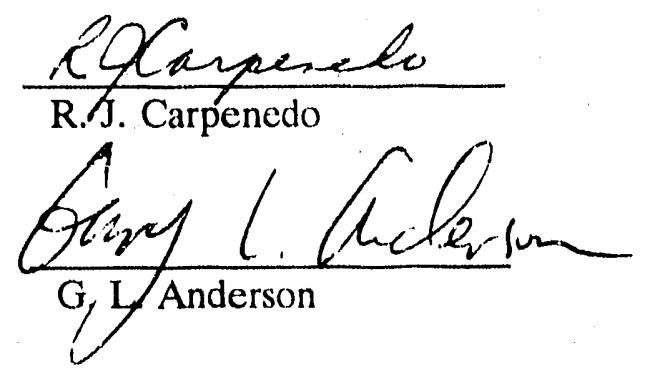

Reviewed by:
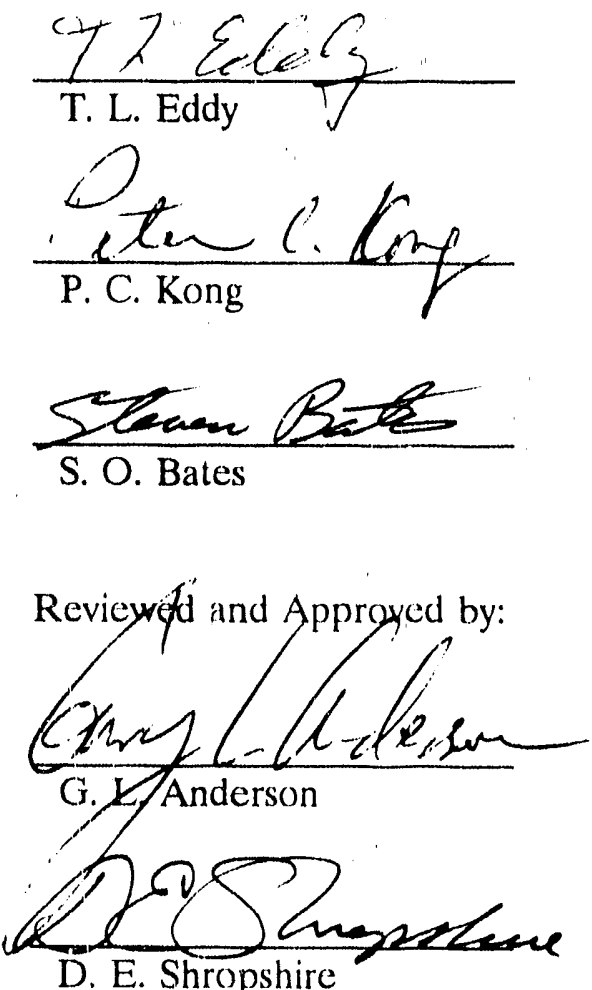

D. E. Shropshire $\frac{1 / 27 / 9 L}{\text { Date }}$

$\frac{1 / 27 / 92}{\text { Date }}$

$\frac{1 / 31 / 92}{\text { Date }}$

$\frac{1-27-9,2}{\text { Date }}$

$\frac{1-27-92}{\text { Date }}$

$31 \operatorname{den} 92$

Date

$\frac{i \cdot i \cdot}{\text { Date }}$

$|-3|-92$

Date 


\begin{abstract}
This report presents a survey and initial assessment of the existing state-of-the-art melter technology necessary to thermally treat (stabilize) buried TRU waste, by producing a highly leach resistant glass/ceramic waste form suitable for final disposal. Buried mixed transuranic (TRU) waste at the Idaho National Engineering Laboratory (INEL) represents an environmental hazard requiring remediation. The Environmental Protection Agency (EPA) placed the INEL on the National Priorities List in 1989. Remediation of the buried TRU-contaminated waste via the CERCLA decision process is required to remove INEL from the National Priorities List. A Waste Technology Development (WTD) Preliminary Systems Design and Thermal Technologies Screening Study identified joule-heated and plasma-heated melters as the most probable thermal systems technologies capable of melting the INEL soil and waste to produce the desired final waste form [Iron-Enriched Basalt (IEB) glass/ceramic|. The work reported herein then surveys the state of existing melter technology and assesses it within the context of processing INEL buried TRU wastes and contaminated soils. Necessary technology development work is recommended.
\end{abstract}




\section{EXECUTIVE SUMMARY}

This report presents the results of a survey and initial technology needs assessment of melter/vitrifiers as key operations for ex situ thermal processing of INEL buried, mixed, TRUcontaminated waste and the surrounding contaminated soil. The unit technologies investigated, based upon a Preliminary System Design Study (EGG-WTD-9594, July 1991) and initial Thermal Technologies Screening Study (EGG-WTD-9449, January 1991), were primarily joule-heated melters and arc/plasma furnaces; although other available furnaces/melters are briefly discussed. The waste of concern is from the Radioactive Waste Management Complex (RWMC) Subsurface Disposal Area (SDA) and is a mixture of hazardous, low-level, radioactive, and transuranic contaminated wastes.

The preliminary process systems design study focused on identifying and determining the appropriateness of the potential process options for buried wastes and identifying the unit technologies that appeared to be workable from a total sysiem standpoint. Data from the preliminary Systems Design Study indicate that all of the ex situ treatment systems considered were of similar cost (excluding ISV applications), but the incineration/melting systems provided the best final waste form. The Preliminary Systems Design Study assumed that various waste streams would be separated to facilitate sorting the TRU from the LLW and other hazardous wastes. The common perception was that processing as-received buried waste (no pretreatment or sorting other than perhaps gross sizing) was not practical using most of the commercial unit technology approaches. Work reported herein indicates high temperature melter technologies exist that may be able to process "as received" wastes with little or no sorting, alihough demonstration is needed.

Companion studies (see EGG-WTD-9449, January 1991 and EGG-WTD-10035, February 1992) provide a broad initial screening (ranking) of available thermal technologies (incinerators and melters). Several melting/slagging or metals oxidation furnace technologies of potential interest, other than the joule-heated, arc, and plasma torch melters discussed herein were identified. These were of sufficient interest to $\mathrm{f}$ ursue further and have been described and evaluated further in EGG-WTD10036, February 1992. These technologies were the cyclone melter, fuel-fired lance melter (Ausmelt), microwave melter, molten metal melter, and molten salt furnace technologies. Although each of these technologies has certain unique features that are of interest, they are presently not as well developed, robust, or otherwise well suited to the high temperature melting/vitrification of the RWMC TRU-contaminated buried wastes. The information collected for the melter assessment reported herein was obtained through visits to potential vendor's facilities, numerous teleconferences with experts in the respective fields, including national laboratories and universities, and a search of available literature. The survey base is believed to be complete and representative of all key domestic suppliers technologies. Suppliers in the field are, however, rapidly changing and emerging, and no international suppliers or labs were surveyed. A questionnaire was used to guide but did not limit the survey. Among other questions, each vendor was asked whether or not their unit or system could process the anticipated average buried waste and soil compositions and produce the desirable glass/ceramic (IEB) final product. They were also asked what typical problem areas existed with their existing designs and what problems were envisioned in processing the INEL buried wastes. Of 
particular interest were areas in which the process and/or equipment would require further development. In all cases, except for PNL, the vendors had no radioactive material processing experience; which limited the value of their input on necessary design modifications for making the unit or system adaptable for use in an alpha-contaminated environmënt. Availability of existing lab/bench pilot and production scale melter systems for potential evaluation/demonstration tests by suppliers were assessed.

Because of high-level waste (HLW) applications development, joule-heated melters (JHM) are the most studied melters for radioactive waste application. Typical operating temperatures are $<1100^{\circ} \mathrm{C}$ and upper limits are $1300^{\circ} \mathrm{C}$. JHM are presently unable (in existing designs) to handle the high-temp-rature melting $\left(>1500^{\circ} \mathrm{C}\right)$ required for the RWMC natural basaltic waste and soil compositions (without adding large quantities of flux to lower viscosity and melt temperature) or the even higher temperatures required to melt and oxidize the large concentration of metals in the waste stream. JHM electrodes and refractory are in contact with the melt/slag and react or corrode excessively at the high temperatures required. Selective low-temperature waste streams could be sorted out for JHM melting, but with an associated increase in overall system complexity due to sorting. The coupled melt and submerged electrode heating is sensitive to melt compositional conductivity. Expected variations in waste stream composition will vary JHM melt viscosity and electrical conductivity considerably and unacceptably, requiring more control or refined waste stream sorting. Processing of small quantities of metals is possible but metals adversely affect melt electrical conductivity and can result in shorting the electrode heating path. Relatively small waste feed particle size and uniform composition are critical for optimum operation. To utilize the JHM process most effectively, the metals should be removed (to avoid melt conductivity problems) and the combustible and organic portion of the waste separated and sent to an incinerator with only the resulting ash going to the melter. The relatively quiet nature of the melters natural convection process and ability to operate with a cold cap on the melt pool tends to reduce the transport of particulates and high vapor pressure metals into the offgas stream. Large volumes and long residence times in the melt are used to ensure uniform product glass. Even when using this approach, high-temperature testing of electrodes, refractories, glass recipes, and melter design configuration must be performed. A design variation on the large ceramic lined JHM for low temperatures $<1100^{\circ} \mathrm{C}$ HLW glass applications is a smaller stirred melter. The forced convection (stirring) in the melt allows for higher process rates at a much smaller size.

Arc/Plasma-heated melters (AHM/PHM) including both arc and plasma torch heated melters are more robust than JHM relative to handling large variations in the incoming waste composition and producing the high temperatures required to process RWMC waste compositions. The heterogeneous mix of metals, noncombustibles, combustibles, and soil can be handled in the "as received" mode, although processing of large quantities of combustibles may be better handled in an incinerator. High and low temperature operation is possible in both reducing and oxidizing melts and atmospheres. Utilization of a cooled skull wall is possible for refractory protection. Arc electrodes or plasma torches are not in contact with the melt materials. This essentially decouples the electrode thermal input from the melt composition (although a component of joule heating is present) and reduces 
opportunity for electrode corrosion. Opportunity to influence gas space and slag chemistry with the choice of plasma torch gas is available. Contrary to initial expectations, more plasma melter vendors are available and more related materials processing work has been done in high-temperature melting of complex ores and typical RWMC waste compositions with PHM than with JHM. One particular PHM configuration has recently been placed in commercial waste treatment application, there are, however, no applications to radioactive wastes.

The arc-heated and plasma-heated melters are based upon high temperature $\left(1500-250()^{\circ} \mathrm{C}\right)$ metals/ore processing and refining technology. They are much more tolerant of leed size (up to 6 in. mesh) and variable feed stock composition. The PHM/AHM can handle all the "as received waste" (little or no sorting required). Their ability to easily reach the higher temperatures required to do this makes them initially more attractive than joule-heated melters. The higher temperatures can however lead to increased volatilization of the high vapor pressure metals, which will be transported with the offgas stream and require offgas system retention for lurther processing. Depending upon feed configuration and the turbulent nature of the plasma arc furnaces, particulates may be generated and transported with offgas. Particulates must be collected by the offgas treatment system. Plasma torch electrode life and maintenance replacement is an engineering issue for PHM. Graphite electrode consumption and protection in an oxidizing atmosphere is an issue for AHM.

If the joule-heated melter concept is to be pursued for high-temperature operation, a total melter system, including electrodes, furnace configuration and materials, power supplies, etc., would have to be developed and tested. If the arc/plasma-heated melter concept is to be used, the high vapor pressure metal problem has to be resolved. If the JHM is to be used in low/medium-temperature applications and the PHM in high-temperature applications, then additional sorting and control, as well as resolution of the HVPM question must be done. Results from this melter technology assessment indicate that the separation of waste stream components is required for application of a joule-heated melter but may not be necessary for an arc/plasma furnace. In all cases design and demonstration of the melter configuration and the attendant feed offgas handling and pouring/casting subsystems for operation in a TRU environment is needed.

Additional process related work is also needed to optimize the IEB melt conditions, verify TRU and metals retention in the IEB product waste form, and to demonstrate melter capability to produce the defined process conditions over the range of possible incoming waste compositions.

As in pyrometallurgy plants, the thermal process unit will only require approximately $10 \%$ of the floor space and $10 \%$ of the capital. The rest of the space and capital will be for feed preparation, offgas treatment, and product handling. Alpha material handling and control will be a key issue. The melter/vitrifier must be developed within the context of a complete process system. A detailed consideration of the complete thermal processing system requirements and preliminary conceptual system designs are provided in EGG-WTD-1(K)58, Fobruary 1992. A survey of offgas systems technology for use with an incinerator and a melter is provided in EGG-W'TD-10(138, February 1992. 


\section{FOREWORD}

This report was prepared for the Waste Technology Development Department of EG\&G Idaho, Inc. under contract to the U.S. Department of Energy Idaho Field Office, Office of Technology Development. Funding was provided under FY-91 Thermal Processing Technologies Technical Task Plan ID-0502-DT, 1991, and ID-040E-2D, 1992, G. L. Anderson, Principal Investigator.

The authors gratefully acknowledge the assistance of INEL coworkers T. L. Eddy, B. D. Raivo, G. A. Reimann, P. C. Kong, S. O. Bates, and others for technical input and review.

The authors are also indebted to numerous lab and vendor representatives, who participated in the survey and provided informative discussions on melter and process technology. 


\section{CONTENTS}

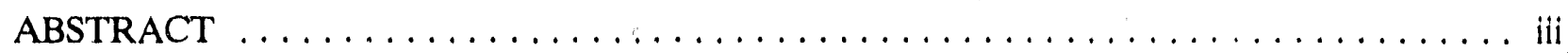

EXECUTIVE SUMMARY $\ldots \ldots \ldots \ldots \ldots \ldots \ldots \ldots \ldots \ldots \ldots \ldots, \ldots \ldots \ldots$

FOREWORD $\ldots \ldots \ldots \ldots \ldots \ldots \ldots \ldots \ldots \ldots \ldots \ldots \ldots \ldots \ldots \ldots \ldots \ldots$ ix

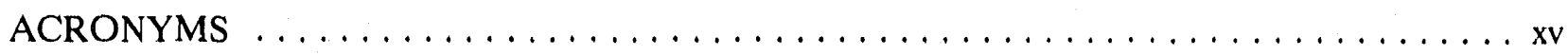

1. BACKGROUND $\ldots \ldots \ldots \ldots \ldots \ldots \ldots \ldots \ldots \ldots \ldots \ldots \ldots \ldots \ldots \ldots \ldots$

1.1 Introduction $\ldots \ldots \ldots \ldots \ldots \ldots \ldots \ldots \ldots \ldots \ldots \ldots \ldots \ldots \ldots \ldots \ldots$

1.2 Waste-Related Considerations $\ldots \ldots \ldots \ldots \ldots \ldots \ldots \ldots \ldots \ldots \ldots \ldots$

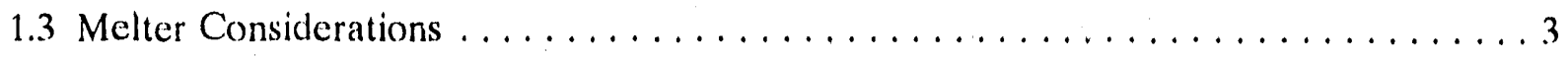

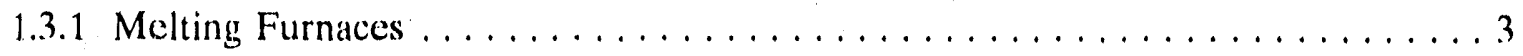

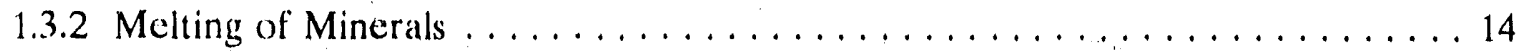

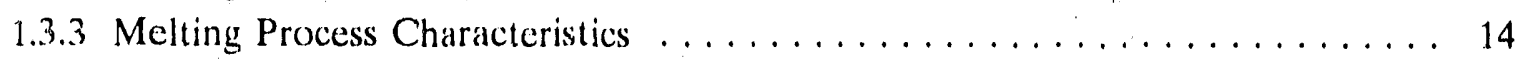

2. DEVELOPER AND VENDOR ASSESSMENT $\ldots \ldots \ldots \ldots \ldots \ldots \ldots \ldots \ldots$

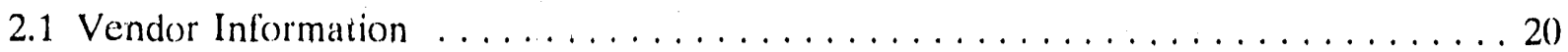

2.2 Joule-Heated Melters $\ldots \ldots \ldots \ldots \ldots \ldots \ldots \ldots \ldots \ldots \ldots \ldots \ldots \ldots \ldots$

2.2 .1 Overview . . . . . . . . . . . . . . . . . . . . . . . 20

2.2.2 National Laboratory Development of JHM Technology . . . . . . . . . . 22

2.2.3 Commercial Development of JHM Technology $\ldots \ldots \ldots \ldots \ldots \ldots \ldots \ldots$

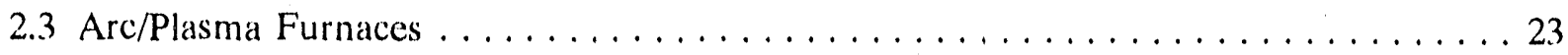

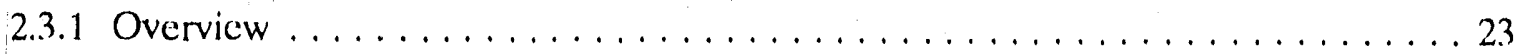

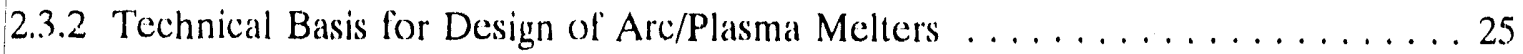

2.3.3 National Laboratory Development of PHM Technology . . . . . . . . . . 26

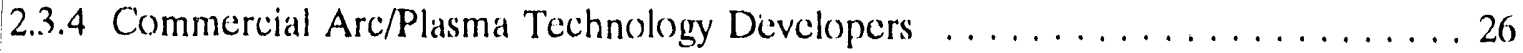

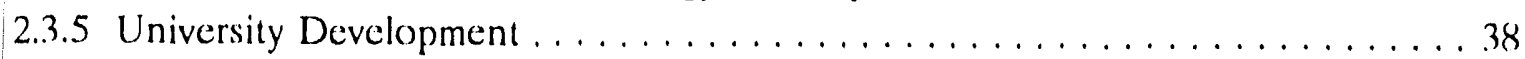




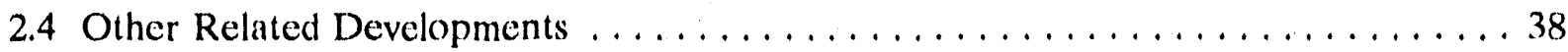

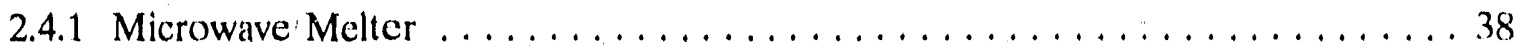

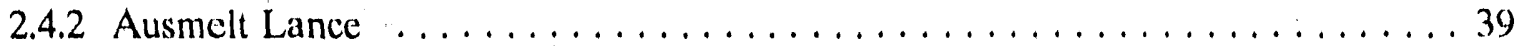

2.4.3 Molten-Metal Bath ............................ 39

3. CONCEPTUAL MELTER PROCESS DESIGNS $\ldots \ldots \ldots \ldots \ldots \ldots \ldots \ldots \ldots$

3.1 Plasma Arc/Torch Furnace Concept $\ldots \ldots \ldots \ldots \ldots \ldots \ldots \ldots \ldots \ldots \ldots \ldots$. $\ldots \ldots$

3.2 AC Transferred Arc Furnace Concept $\ldots \ldots \ldots \ldots \ldots \ldots \ldots \ldots \ldots \ldots \ldots$

3.3 DC Transferred Arc Furnace Concept . . . . . . . . . . . . . . . . 46

3.4 Joule-Heated Melter Concept $\ldots \ldots \ldots \ldots \ldots \ldots \ldots \ldots \ldots \ldots \ldots \ldots \ldots$

4. CRITICAL ISSUES AND DEVELOPMENT NEEDED $\ldots \ldots \ldots \ldots \ldots \ldots \ldots$

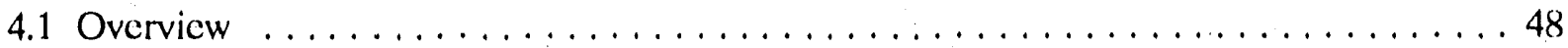

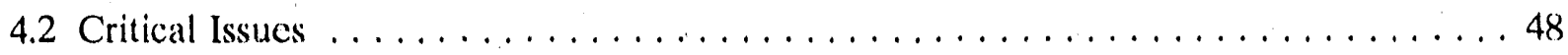

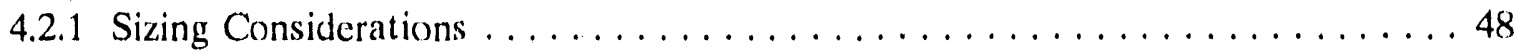

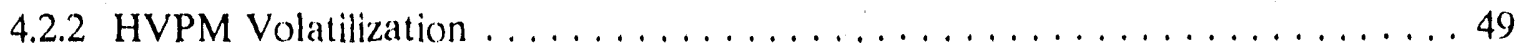

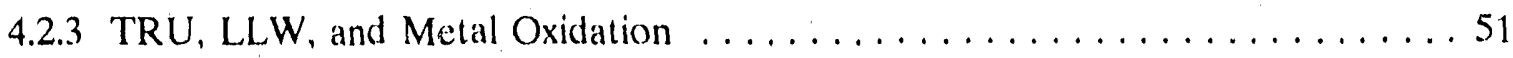

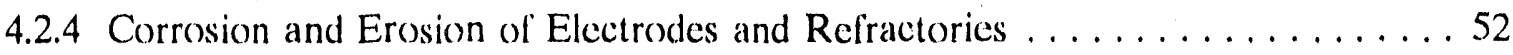

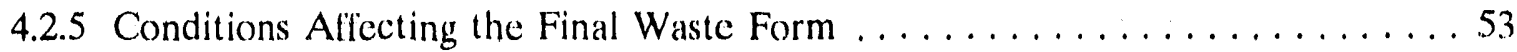

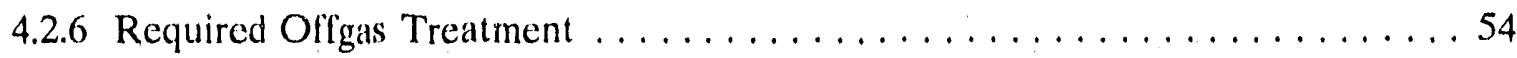

4.3 Summary of Developments Needed $\ldots \ldots \ldots \ldots \ldots \ldots \ldots \ldots \ldots \ldots \ldots$

4.4 Facilities Available for Experiments $\ldots \ldots \ldots \ldots \ldots \ldots \ldots \ldots \ldots \ldots \ldots$

5. CONCLUSIONS AND RECOMMENDATIONS $\ldots \ldots \ldots \ldots \ldots \ldots \ldots \ldots \ldots$

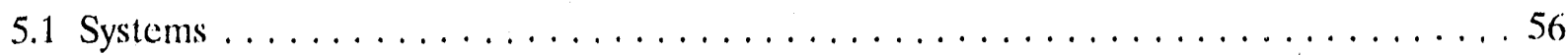

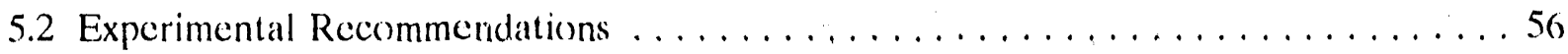

6. REFERENCES ................................ 59

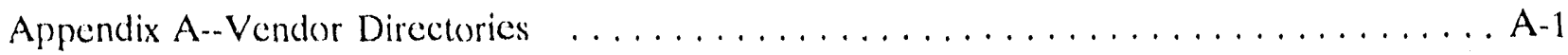




\section{FIGURES}

1. Three types of electrically heated shaft furnaces: three-phase submerged arc,

Scorpion three-phase pyrolizer, and the Westinghouse type plasma-assisted cupola $\ldots \ldots 6$

2. Three types of hearth furnace: single water cooled electrode dc, single graphite electrode $\mathrm{dc}$, and the three ac electrode furnace $\ldots \ldots \ldots \ldots \ldots \ldots \ldots$

3. Shallow hearth furnace for steel $\ldots \ldots \ldots \ldots \ldots \ldots \ldots \ldots \ldots \ldots \ldots \ldots \ldots$

4. Arc/plasma torch mode of operation: a) transferred-arc mode with one electrode in the torch and the other the slag/melt and b) nontransferred-arc mode with both electrodes in the torch and the plasma plume as the heater $\ldots \ldots \ldots \ldots \ldots \ldots \ldots 9$

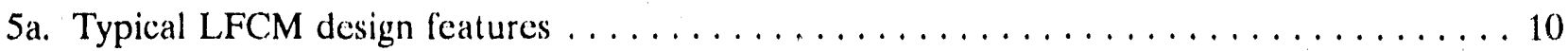

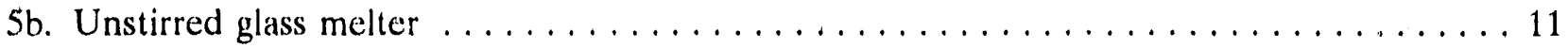

5c. Buried waste joule-heated melter vitrification treatment system $\ldots \ldots \ldots \ldots \ldots \ldots \ldots 12$

6. Stirred glass melter $\ldots \ldots \ldots \ldots \ldots \ldots \ldots \ldots \ldots \ldots \ldots \ldots \ldots \ldots \ldots \ldots \ldots$

7. Freeze wall or skull melt $\ldots \ldots \ldots \ldots \ldots \ldots \ldots \ldots \ldots \ldots \ldots \ldots \ldots \ldots \ldots$

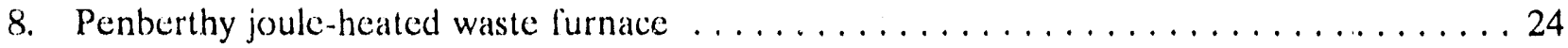

9. Retech plasma centrifugal reactor $\ldots \ldots \ldots \ldots \ldots \ldots \ldots \ldots \ldots \ldots \ldots \ldots \ldots$

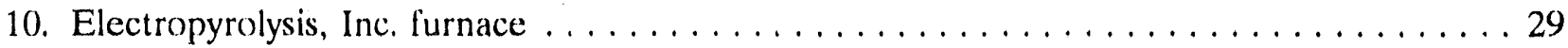

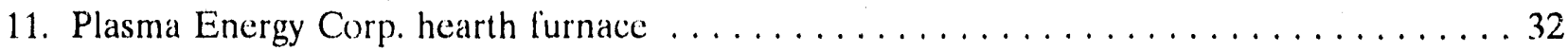

12. Lectromelt 36 MVA copper matte furnace $\ldots \ldots \ldots \ldots \ldots \ldots \ldots \ldots \ldots \ldots \ldots \ldots$

13. Lectromelt 72 MVA phosphorous furnace $\ldots \ldots \ldots \ldots \ldots \ldots \ldots \ldots \ldots \ldots \ldots$

14. Lectromelt $16.5 \mathrm{MVA}$ ferro-chromium furnace $\ldots \ldots \ldots \ldots \ldots \ldots \ldots \ldots \ldots$

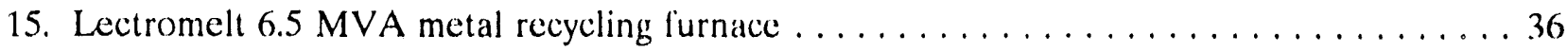

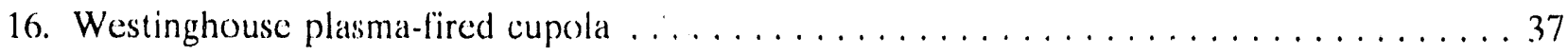

17. Conceptual process flow diagram for plasmatarc process $\ldots \ldots \ldots \ldots \ldots \ldots \ldots \ldots \ldots$

18. Conceptual process flow diagram for ac carbon-arc process $\ldots \ldots \ldots \ldots \ldots \ldots \ldots \ldots . \ldots 4$

19. Conceptual process flow diagram for de carbon-arc process $\ldots \ldots \ldots \ldots \ldots \ldots \ldots$ 
20. Conceptual process flow diagram for joule-heated melter $\ldots \ldots \ldots \ldots \ldots \ldots \ldots \ldots$

\section{TABLES}

1. Organizations developing melting technology for processing wastes $\ldots \ldots \ldots \ldots \ldots 21$

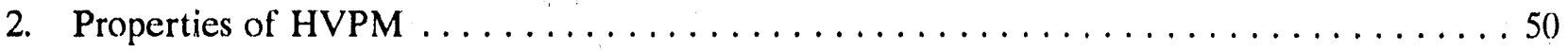

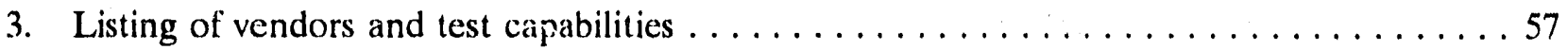




\section{ACRONYMS}

BSG borosilicate glass

CERCLA Comprehensive Environmental Response, Compensation, and Liability Act

CFR Code of Foderal Regulations

DOE Department of Energy

DOT Department of Transportation

EAF electric arc furnace

EPA Environmental Protection Agency

Flux Material added to melt to increase viscosity, conductivity

HLW high-level waste

IEB iron-enriched basalt

INEL Idaho National Engincering Laboratory

ISV in situ vitrification

JHM joule-heated melter

LDR Landfill Disposal Requirements

MAP mixed activation product

MFP mixed fission product

NRTS National Reactor Testing Station

PHM plasma-heated melter

RCRA Resource Conservation and Recovery Act

Redox reduction or oxidation state in the melt, slag or atmosphere

RFP Rocky Flats Plant

RWMC Radioactive Waste Management Complex

LLW low-level waste 
SDA Subsurface Disposal Area

TPT Thermal Processing Technologies project

TRA Test Reactor Area

TRAMPAC DOT nuclear waste transportation requirements

TRU transuranic

TSA Transuranic Storage Area

USBM U.S. Bureau of Mines

USGS U.S. Geological Survey

WIPP Waste Isolation Pilot Plant 


\section{MELTER DEVELOPMENT NEEDS ASSESSMENT}

\section{BACKGROUND}

\subsection{Introduction}

In support of the EG\&G Idaho Buried Waste Integrated Demonstration Program mission of developing and demonstrating technologies for the permanent environmental restoration of the INFL and similar site wastes, the Thermal Frocessing Technologies Demonstration Project was established to identify, evaluate and demonstrate the most promising thermal processes capable of producing a superior final waste form. Based upon the results from the Preliminary Systems Design Study, ${ }^{1}$ and initial thermal technologies screening efforts, ${ }^{2}$ the initial focus has been on the evaluation of melter/vitrifier systems technologies. This document describes a survey and initial assessment of the melter technologies within the context of possible process systems and identifies areas needing further development to provide for an integrated demonstration of the melter systems application to INEL buried mixed TRU wastes.

This ieport is divided into seven sections. Section 1 provides background on the subject waste streams, the final waste forms desired, and general melter processing considerations. Section 2 presents an assessment of the existing melter technology available and vendor capabilities to provide systems and/or components. To help place the melter technology within the proper context, Section 3 describes several simple conceptual process designs. Critical open questions or potential technology problem areas related to melters are then identified and discussed in Section 4, along with a summary of development work needed, possible vendors, experimental facilities, and recommended tests. Section 5 summarizes conclusions and iecommendations. References are contained in Section 6, and Appendix A contains directories on vendors for the various melters discussed.

The focus of this report is melter technologies. It is, however, necessary to consider melter requirements in the context of a complete thermal processing system for RWMC buried wastes. This issue has therefore, been treated briefly. More detailed consideration of the complete thermal processing system requirements and options for the desired high integrity leach resistant waste form (IEB glass/ceramic) is provided in Reference 3.

\subsection{Waste-Related Considerations}

Beginning in 1952, low-level radioactive waste (LLW) generated at the INEL was buried in the SDA at the RWMC. Starting in 1954, the INEL began receiving, for burial, low-level alpha emitting waste (referred to as alpha or TRU wastes). Most of the transuranic wastes were generated from the production of nuclear weapons at the Rocky Flats Plant near Golden, Colorado. The LLW and TRU wastes were disposed of together in trenches and pits until 1972, when because of safety 
concerns this practice was stopped. At that time, the DOE began segregating the wastes and placing the TRU-contaminated waste in retrievable surface storage at the Transuranic Storage Area (TSA).

In November 1989, INEL was placed on the National Priorities List (NPL), the EPA's list of priority sites for cleanup. Placement on this list mandaies the remediation of the SDA under the Comprehensive Environmental Response, Compensation, and Liability Act (CERCLA). Using the CERCLA decision process, a remedial action option can be classified as: (a) no action, (b) an in situ treatment and disposal, or (c) ex situ treatment and disposal. Permanent environmental restoration of the INEL will likely demand the retrieval and treatment of the buried mixed wastes to provide a final waste form that meets increasingly stringent disposal requirements and public acceptance.

Thermal processing technologies have been'identified via the Preliminary System Design Study as key elements in the preferred ex situ treatment options for the remediation of the mixed TRU waste and contaminated soil at the INEL: The most promising of these technologies, joule-heated melters and arc/plasma furnaces are addressed in this report. Other melter technologies, e.g., fuel fired, microwave, induction melters, etc. are briefly considered. References are given in this report that provide an assessment and background on a broad range of thermal technologies including incinerators, slagging incinerators, and melters.

The buried waste input waste stream for thermal processing is potentially composed of a heterogeneous mix of combustible organics, noncombustible metal oxides, metals, and contaminated soil. The special case oversized or overly radioactive wastes that may be encountered will require separation and pretreatment as special case wastes prior to entering the process stream. The bulk of the INEL buried waste was originally contained in lined metal drums and in wooden or cardboard boxes. Many of these containers have deteriorated over time. Various wastes are located in an unsorted manner in the various pits and trenches. Soil is intermingled with the containers. The underburden (and possibly overburden) soil is also contaminated. To treat this heterogeneous mixture of waste and soil, it is likely the combustibles (most are organics present in cemented or in sludge forms) will require incineration, utilizing a rotary kiln or equivalent. The resulting noncombustible ash and metal oxides will have a relatively low-temperature melting (dissolution) range $\left(900-120()^{\circ} \mathrm{C}\right)$. The basaltic soil, which has relatively high aluminum oxide and iron oxide content, will require a medium-to-high temperature melting range $\left(12(0)-150()^{\circ} \mathrm{C}\right)$. The carbon steel and stainless steel will require high temperatures $\left(150(0)-2000^{\circ} \mathrm{C}\right)$ to melt and/or oxidize within a reasonable time period. The employment of different temperature melters for processing would require sorting. Use of a high-temperature melter would minimize the need for sorting. The higher temperature melters are however more likely to volatilize high vapor pressure metals. Methods of retaining these metals as oxides in the slag require further demonstration testing.

To obtain the optimum final waste form with high mechanical and thermal stability, as well as low chemical leachability, it appears that a ceramic (crystalline) waste form is the best choice, and a glassy (vitrified) waste form is second best. The natural mix of waste and soil is an IEB compesition that forms a glass/ceramic dependent upon cooling rates. Additional considerations are required to 
minimize leaching of the radioactive components; a discussion of which is beyond the scope of this paper, but has been addressed in other related publications. ${ }^{3,4}$

Obtaining the desired final wuste form will depend not only on the melt composition, but on how the melt or slag is cooled or processed after melting and dissolving. The basaltic soil will have higher temperature requirements than a borosilicate glass frit, but will result in substantial volume reduction rather than an increase, a better performing final waste form, and is the natural result of melting the INEL waste and soil compositions.

\subsection{Melter Considerations}

\subsubsection{Melting Furnaces}

Furnaces are simply chambers in which thermal energy is supplied in order to physically and/or chemically transform materials from one form to another. There are a number of ways to clasisify furnaces, i.e., by method of heating, by physical configuration, by type of material processed, elc. For the purposes of this study "melters" are high-temperature furnaces intended to melt, slag, or vitrify noncombustible solids. Incinerators are furnaces intended for the pyrolyzation and combustion of combustible materials.

Incinerators. Incinerators in general do not produce sufficient temperatures or employ sufficient residence times to melt mineral matter into a slag, but instead produce an ash product. They are particularly designed for the processing of waste with a high combustible !oading. Depending upon temperature level and oxygen availability, they may volatilize and pyrolyze organics or combust them. Incinerators can be either fuel or electrically fired, but are generally fuel fïreci. Fuel lïring produces large amounts of combustion products that must be treated with the oflgas system. For wastes containing TRU, it is highly desirable to minimize off-gas volumes and flow rates (particulate entrainment) and particulates must be trapped.

Some incinerators can be operated in a "slagging mode" in which the noncombustible ash is partially melted/dissolved during the short residence time in order to produce a more easily handled solid effluent (vitrified ash or slag frit). These are referred to as "slagging incinerators," and are not classified as "melters." The focus of this study is on melters. Incinerators are surveyed and assessed in Reference 5.

Melters. Melters are generally large refractory lined lurnaces designed primarily for the melting/smelting or vitrification of noncombustible materials (metals, metal oxides, soils/ores, glass formers). They can generally pyrolize and/or combust a considerable fraction of combustible organics as well, but this is not generally their primary purpose. Melter/vitrifiers do not necessarily melt all materials in the bath. Some higher temperature melting materials are dissolved in the molten slag. Melting furnaces can be fuel fired or electric fired and various configurations are possible in both 
types. Hearth furnaces and shaft furnaces are the two basic configurations that have been developed for high-temperature material processing in which a molten slag or glass is produced.

Shaft Furnaces. Shaft configuration smelting furnaces (see Figure 1) are well represented in the pyrometallurgical industry; fuel fïred, electrically fired, and hybrids are used. Reaction of upwardly moving hot gas with the downward moving burden yields excellent thermal efficiency. The archetypical shaft furnace is the iron making blast furnace in which a downward moving charge of iron ore, coke, and limestone is reacted at high temperature to produce high carbon iron and a slag. A few blast furnaces have been operated with arc/plasma assist heating of the entering air. Ferroalloys, such as ferrosilicon and silicon metal, are produced in the three-phase submerged arc furnace, which uses carbon electrodes; the downward moving charge consists of silica lumps and coke for silicon metal and a source of iron for ferrosilicon. The cupola furnace, in use for over 100 years, produces cast iron from steel and iron scrap and coke. Plasma torch assist heating has also been applied to cupolas. Westinghouse developed a plasma-assisted cupola with EPRI sponsorship for use in processing scrap metals at the General Motors Central Foundry. Attempts have been made to apply this concept to the treatment of PCB-contaminated soil. ${ }^{a}$ Although not a melter, the Slagging Pyrolysis Incinerator (SPI) was an initial attempt to develop and apply a fuel fired shaft furnace to combustible mixed INEL wastes in a slagging mode. ${ }^{\circ}$

Hearth Furnaces. Metallurgical hearth furnaces may he fuel fired or electrically heated and include the obsolete fuel fired open hearth for melting and refining of steel and various reverberatory furnaces for melting and/or smelting of aluminum and copper. Also included in the basic hearth design are arc/plasma furnaces, plasma torch furnaces, and joule-heated melters.

Arc/Plasma Furnaces. Fuel fired melters are generally limited to lower temperature smelting by maximum flame temperatures and heat transfer efficiency. Fuel fired melters produce large quantities of offgas requiring treatment. The focus of this study has therefore been upon electrically heated melters. Electrically fired hearth furnaces (see Figure 2) are presently common in the pyrometallurgical industry for smelting of slags. These furnaces generally consist of a relatively shallow hearth for the containment of the molten slag with a number of carbon electrodes arcing to the slag. Alternating or direct current power supplies may be used. Furnaces can be extremely large; hearths of $108 \times 35$ ft with six 65 in. diameter electrodes with 36 MVA of power have been built." Figure 3 shows a shallow hearth type electric furnace as used by steel mills to melt steel. The use of refractories is quite sophisticated. Plasma furnaces utilize a plasma gas torch to supply energy to the melt. The Retech Plasma Centrifugal Reactor is a rotating hearth furnace, ${ }^{7}$ utilizing a transferred are plasma torch. Most plasma fired waste processing devices are variations of the hearth furnace concept.

a. Personal communication with Shyam Dighe, Westinghouse Idaho Nuclear Company, July 1, 1991. 
Arc/plasma Torches. These plasma torches can be operated in a translicrred-arc, nontransferredarc, or dual mode. In the transferred-arc mode, one electrode is in the torch and the other electrode is the slag/melt as shown in Figure 4(a). This mode is the most efficient for converting electrical energy to thermal energy, but may not be as stablo under varying melt conditions as the nontransferred mode. In the nontransferred-are mode [see Figure 4(b)], both electrodes are located "in the torch and the plasma plume or flame is blown out of the torch lor heating, (like a blow torch). The nontransferred torch usually uses more gas flow, and with the water-cooling of two electrodes instead of one, is usually less efficient but easier to control than the transferred-are torch. Combinations provide some of the advantages of both, but incur additional costs.

Joule-Heated Melters. JHMs were developed for the glass industry and are resistively heated by passing an electric current through the melt between submerged electrodes. Electrodes can be Inconel 690, molybdenum, carbon, and other materials, depending on melt temperature and composition. They can be inserted into the melt from the sides, top, or bottom. Joule melters are started by melting a shallow layer with a gas $t c$. ch or by sprinkling conductive material on the surface between electrodes to initiate current llow and resistive heated melting. Most joule melters are large ceramic lined chambers that rely upon natural convection mixing and long residence times to produce a uniform melt. The JHM's of this type are limited in production capacity by their surface area 10 $4 \mathrm{ft}^{2}$ per ton per day. Figure Sa shows a typical JHM (PNL-based design) for processing of HLW with slurry leed. Figure 5b shows a large-scale lab JHM of Penberthy design utilized by INEL in early IEB development work. ${ }^{4}$ Figure $5 c$ shows a proposed modified PNL JHM design for buried wastes. Stirred melters (see Figure 6 ) have much higher capacity per unit of surface area- $.5 \mathrm{ft}^{2}$ per ton ner day. Electrode corrosion is a function of electrode material, melt temperature, and the chemistry of the melt. Inconel is quite corrosion resistant, but has a low melting point, limiting the melt temperature to $1150^{\circ} \mathrm{C}$. Carbon and molybdenum have much higher temperature limits, but are subject to oxidation.

Induction Furnaces. Induction furnaces are commonly used for the relatively small scale melting of metals for the casting industry. For many years, WERF has been induction melting LLW contaminated stainless steel to reduce volume." Induction melting consists of creating a time varying clectromagnetic field in a crucible by passing an ac current through a coil around the crucible. Higher frequencies than the normal line frequency of $60 \mathrm{~Hz}$ are gencrally required. The success of the induction melting concept for the consolidation of contaminated metal indicates that it might have application to the treatment of the metal portion of the SDA waste.

Microwave Melters. Microwaves have an extremely high frequency lield (in the gigahertz range), for example, the home microwave oven operates at $22 \mathrm{GHz}$ with a power level of about a kilowatl, however large radars have power levels of megawalts. In order to melt waste using microwaves, the charge material needs to be placed in a tuned cavily to enable efficient use of mierowave power. Rocky Flats has done development work on a microwave waste processing technology. ${ }^{10,11}$ 


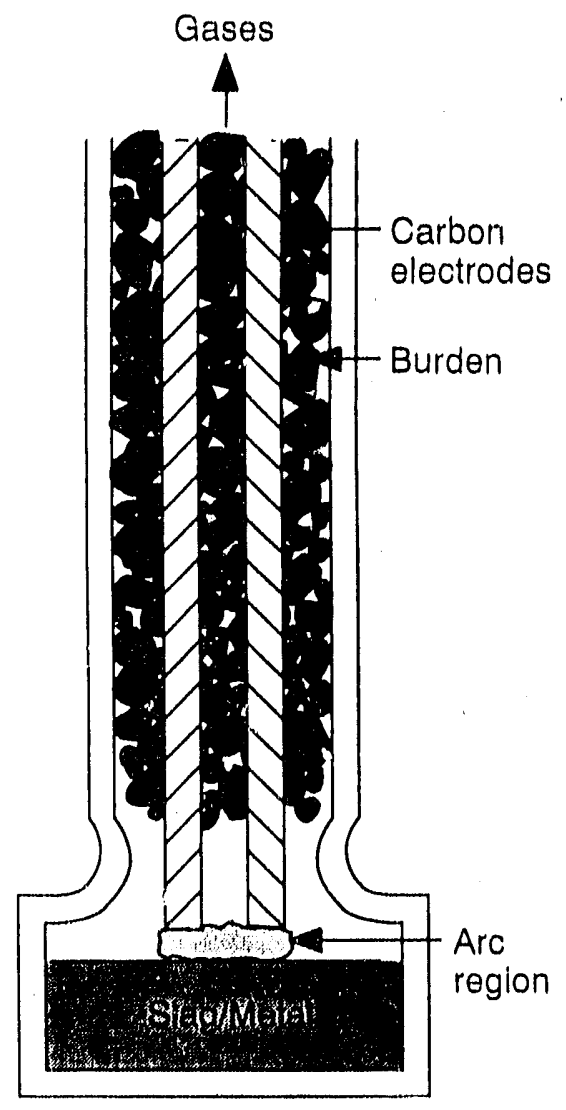

Submerged Arc
Gases
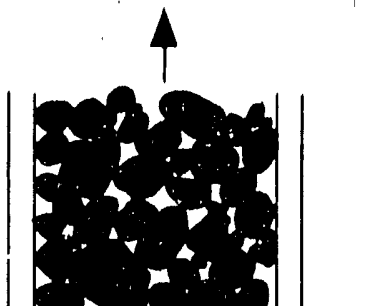

$\therefore \because \because ?$ Burden
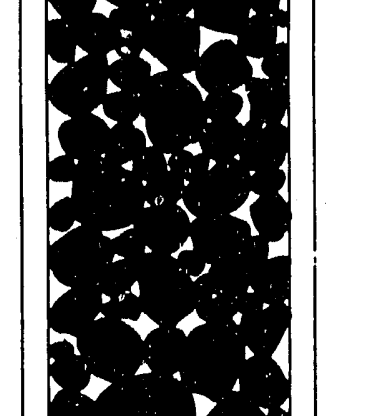

transferred

plasmlc

torches

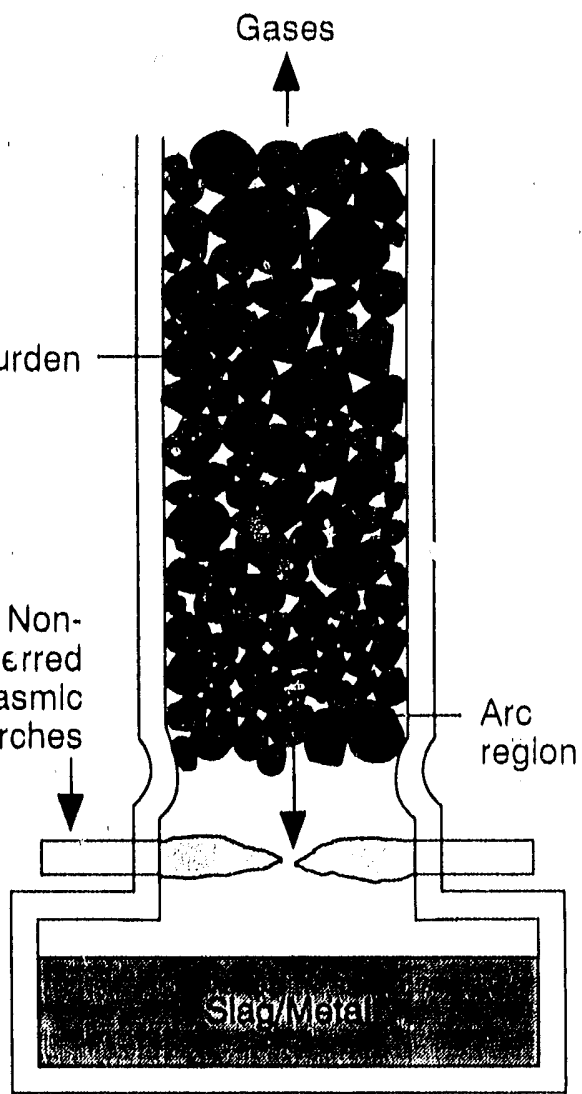

Plasmic assisted cupola

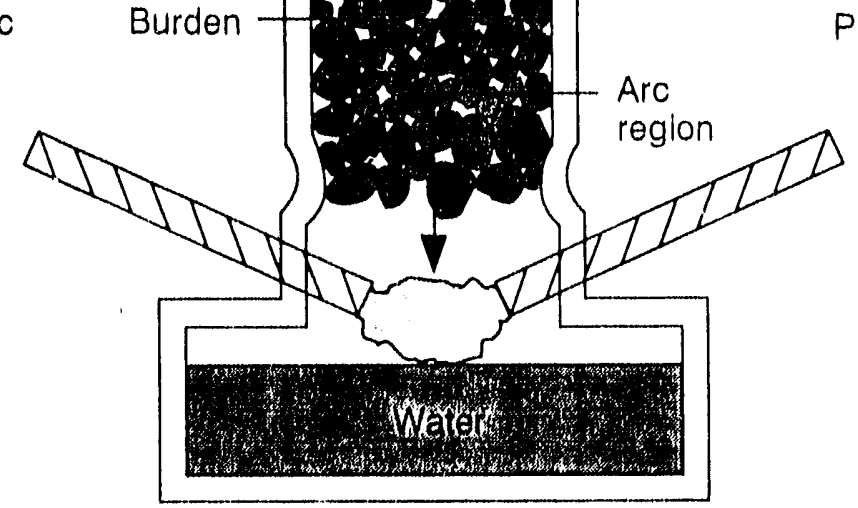

Scorpion pyrolizing furnace

Figure 1. Three types of electrically heated shaft furnaces: three-phase submerged arc, Scorpion three-phase pyrolizer, and the Westinghouse type plasma-assisted cupola. 


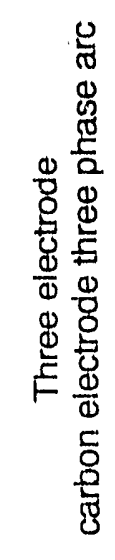

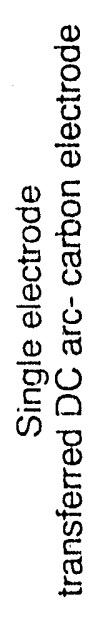
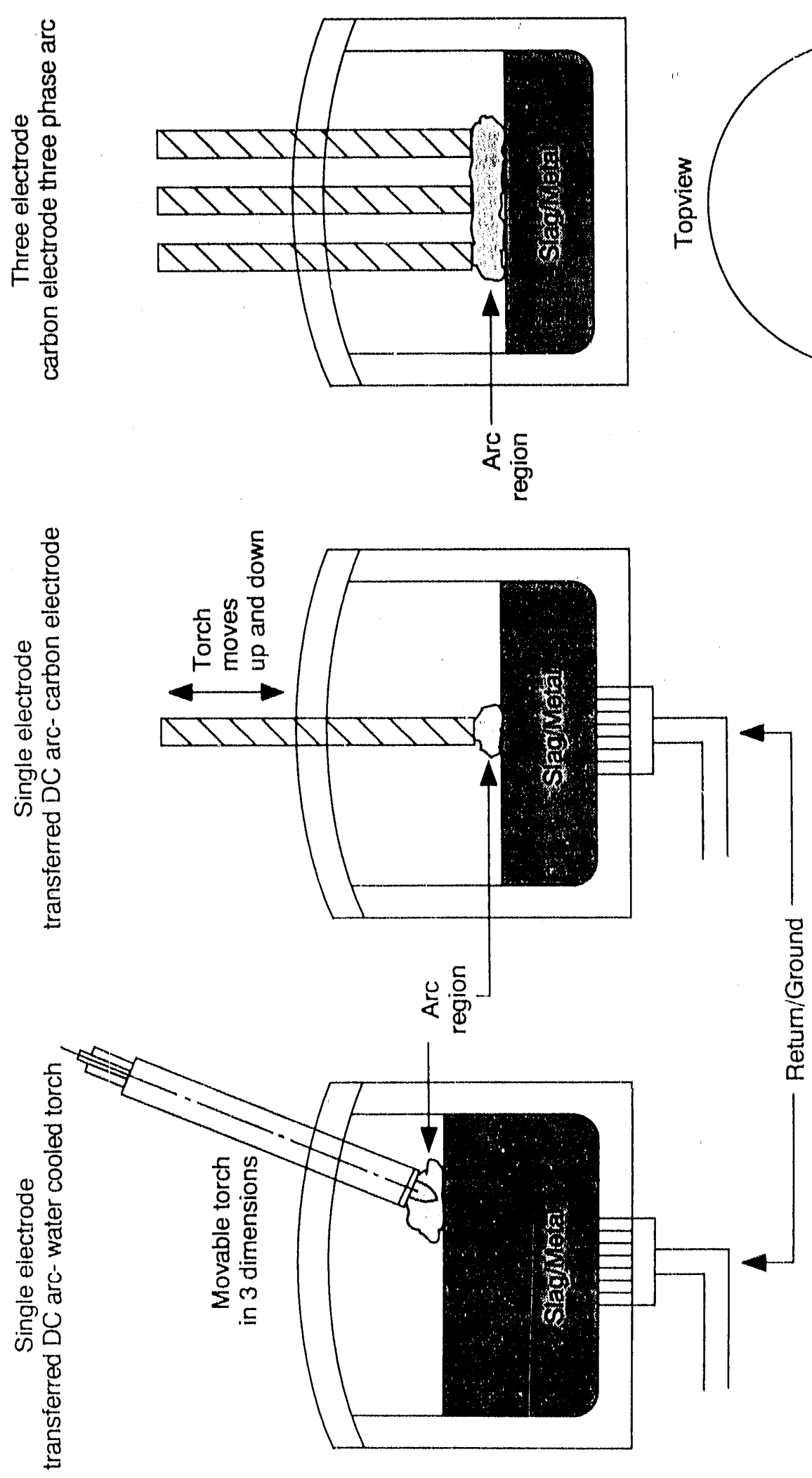

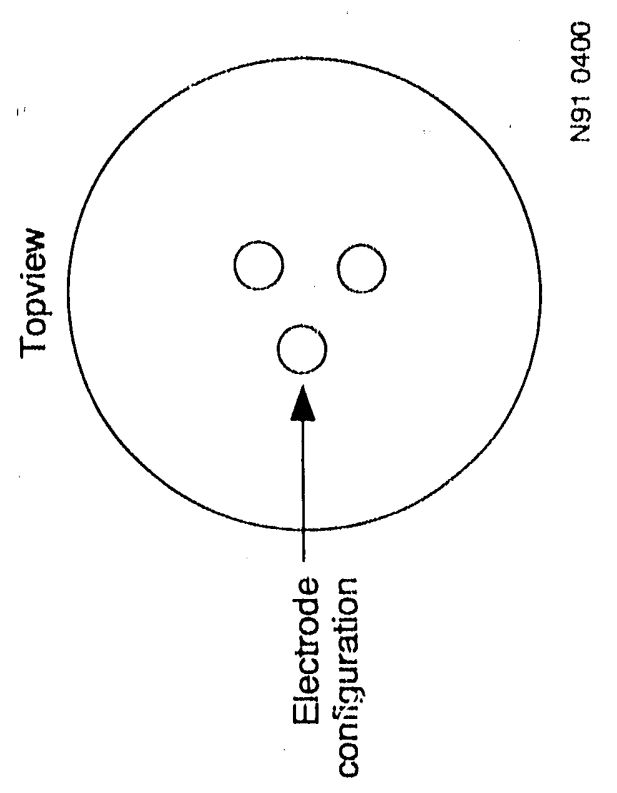

葛

몸

过

8
8
0
$\frac{0}{0}$
$\frac{8}{8}$
$\frac{8}{8}$

岕

品

is

o

學

돈

\&

范点

导焉

过

$F$ i

त

๑ 8

产嘉 


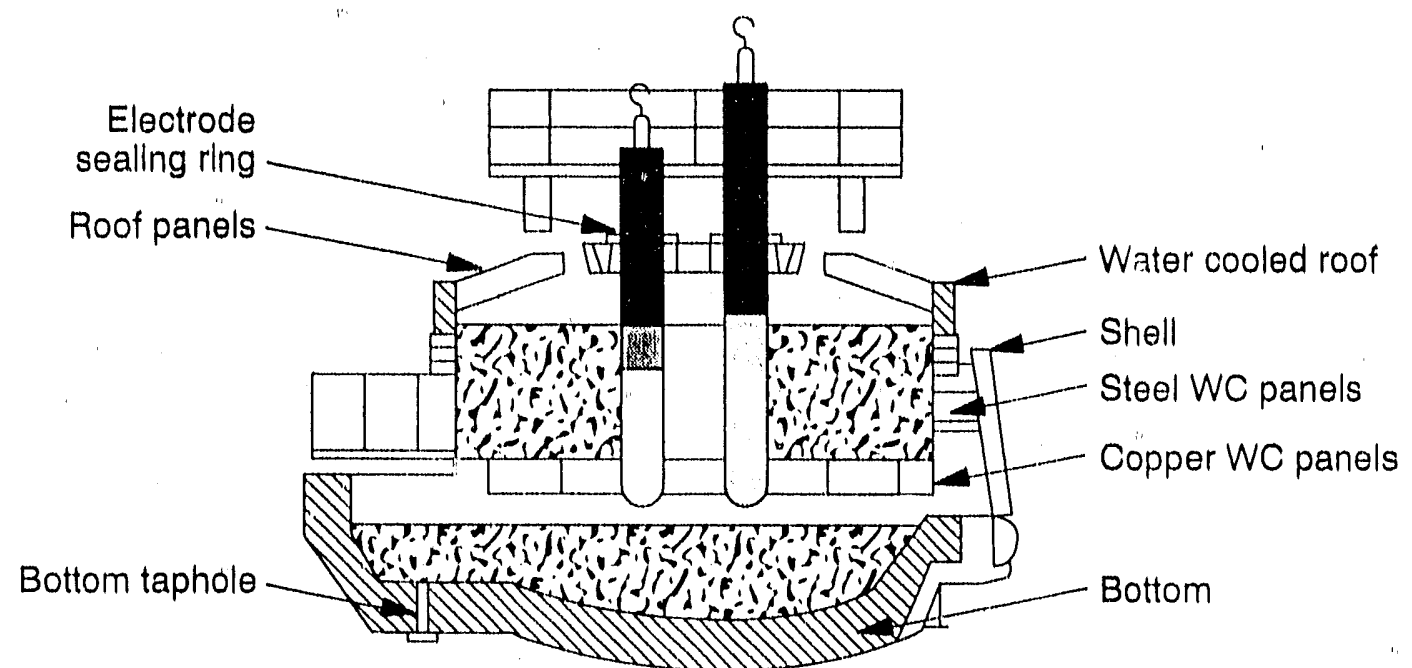

N92 0008

Figure 3. Shallow hearth furnace for steel. 
Plasma torch types

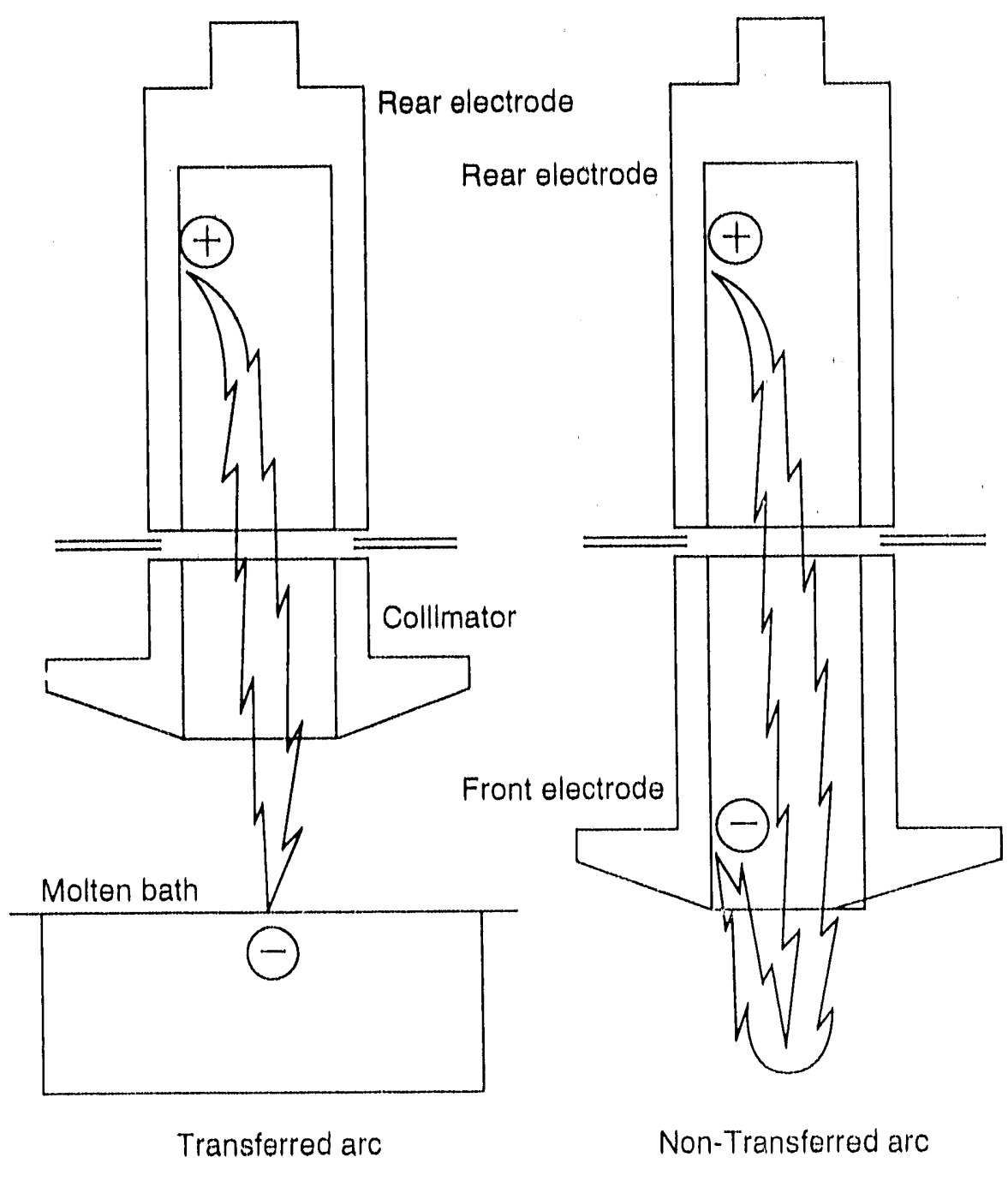

N91 0161

Figure 4. Arc/plasma torch mode of operation: a) transferred-arc mode with one electrode in the: torch and the other the slag/melt and b) nontransferred-arc mode with both electrodes in the toich and the plasma plume as the heater. 


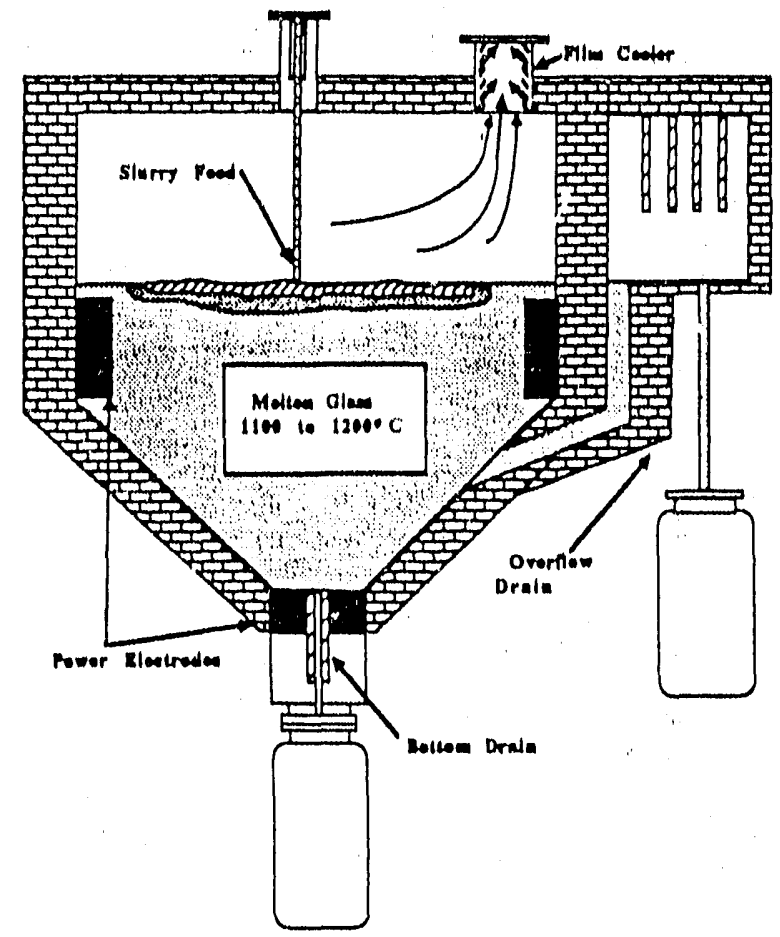

Figure 5a. Typical LFCM design features. 


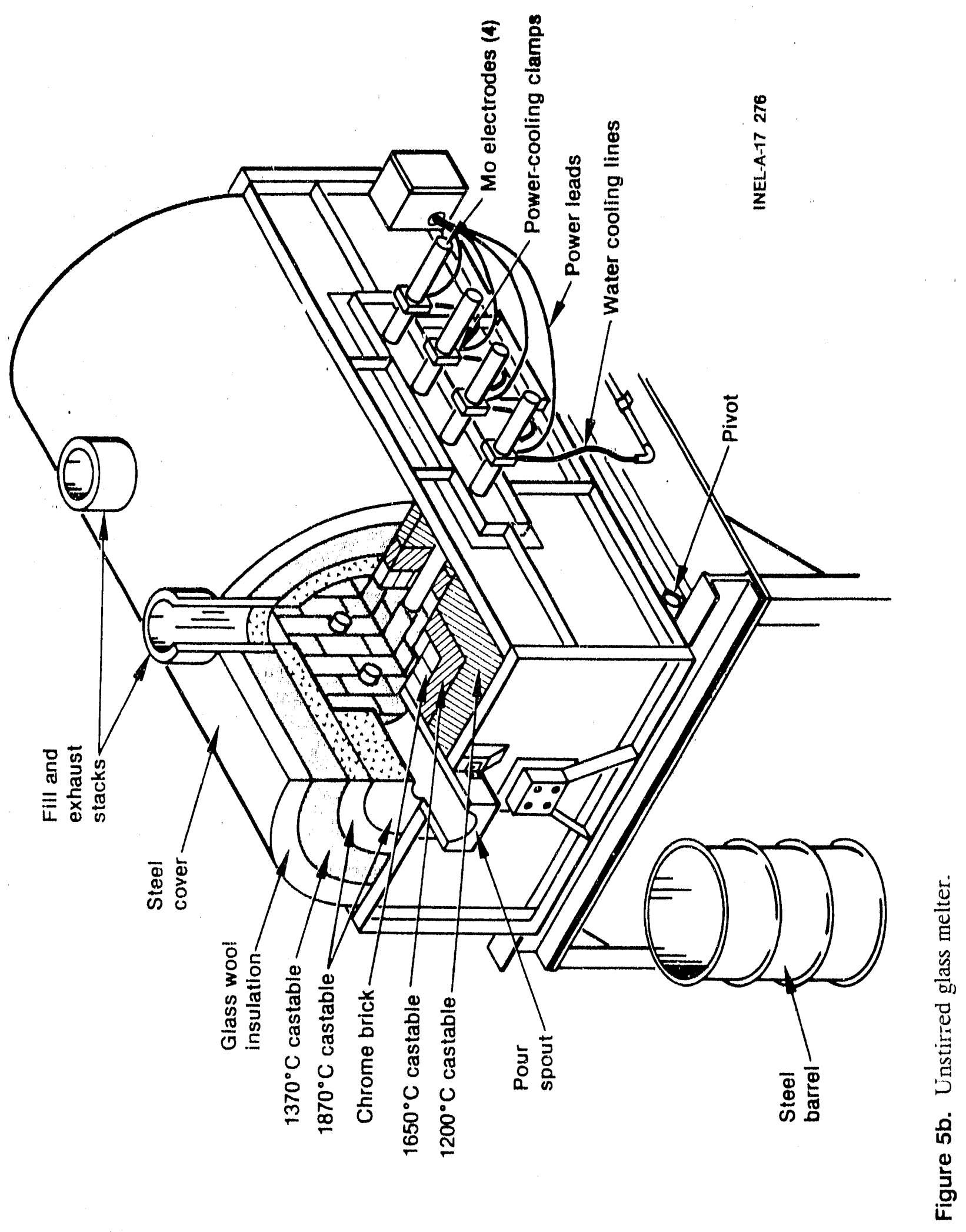




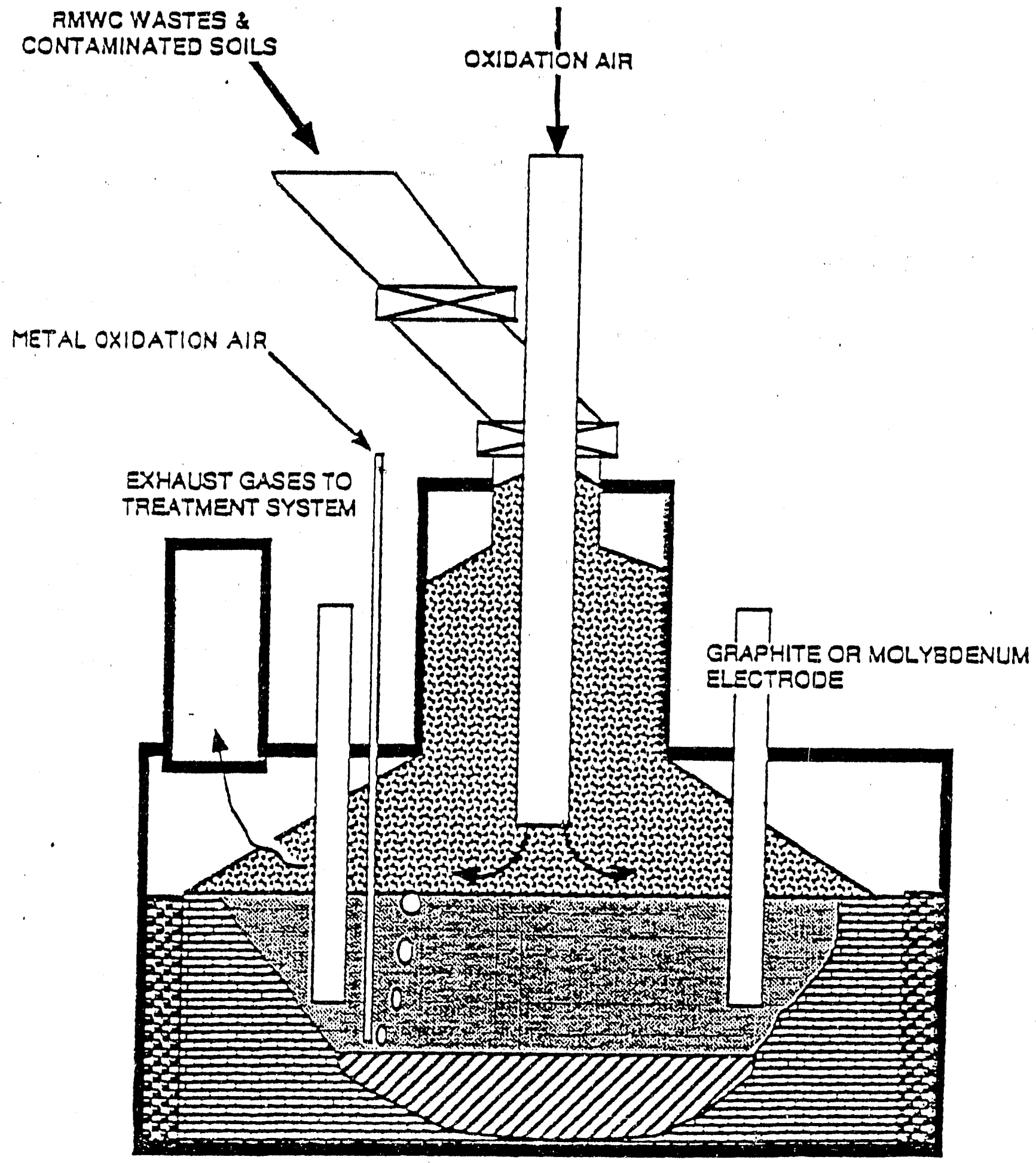

Figure 5c. Buried waste joule-heated melter vitrification treatment system. 


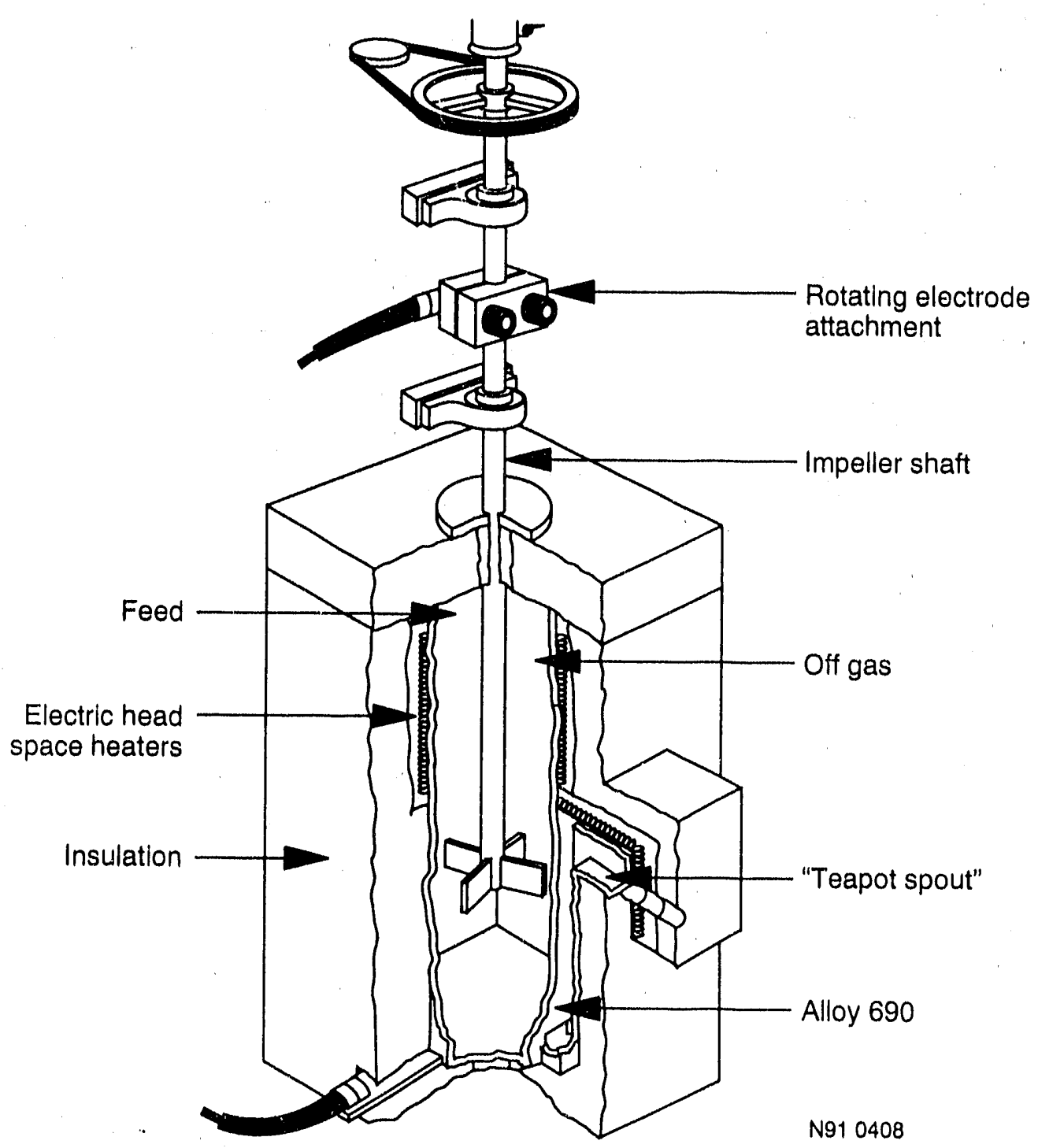

Figure 6. Stirred glass melter. 


\subsubsection{Melting of Minerals}

The melting and dissolving of waste materials and soil to produce a fluid slag of desired properties can potentially be accomplished by a number of methods. The two of primary interest for this report are: plasma or arc melting, and joule-heated melting passing a current through the material to be melted. In most cases of plasma/arc melting there is also a joule component of heating involved, which will in fact do much of the heating. The melting of these materials bears many resemblances to pyrometallurgy. In fact, pyrometallurgy technology is a great resource for experience to apply to the development of waste vitrification technology.

The major difference between existing pyrometallurgy technology and the melting of INEL SDA waste is that the SDA waste is essentially a very complex (heterogeneous) ore. Because material values will not be extracted from the process, however, the processing difficulties are somewhat reduced. In general, joule-heated melting must be done at lower temperatures than arc/plasma melting; joule-heated melters use immersed electrodes that are subject to corrosive attack by the melt. The materials available for electrodes are limited: graphite, molybdenum, and Inconel 690 are the most applicable. INEL basaltic soil melts between 1500 and 170$)^{\circ} \mathrm{C}$. Although both graphite and molybdenum can handle the temperature, they are easily oxidized. Inconel 690 is oxidation resistant but its melting temperature limits it to operation below $1150^{\circ} \mathrm{C}$. Alkali and boron flux additives can be used to reduce the melting point of INEL soil so that joule-heated melters are feasible. This leads, however, to volume increase and less durable final waste forms. There are essentially no melt temperature limitations for arc/plasma processes.

\subsubsection{Melting Process Characteristics}

The mixture of elements in the waste will form one or more slag phases and perhaps a metal phase, each with a distinct melting point and the constituents (elements and/or compounds) will have various vapor pressures above the melt. The oxidation state of the melt will have a strong effect on the number and composition of the phases present. It is desirable and may be necessary to prevent high vapor pressure elements or compounds from escaping into the gas phase above the melt. The elements or compounds of the elements $\mathrm{Cd}, \mathrm{Pb}, \mathrm{Zn}, \mathrm{Hg}$, and others will have high vapor pressures at the temperatures required for melt processing. If these elements can be kept in the slag phase it will not be necessary to develop a separate process for capturing (offgas system) and immobilizing them.

The reduction/oxidation (redox) state of the melt is a key definer of the process. Most melters can have a different oxidation state in the plenum above the melt than in the melt. The redox state in the melt can be controlled by injection of oxygen or air into the melt bath; conversely, admission of oxygen or air into the space above the melt can be used to control the redox state in the atmosphere above the melt. If the space above the melt is oxidizing, hot enough, and there is sufficient residence time, organic compounds will oxidize to $\mathrm{H}_{2} \mathrm{O}, \mathrm{CO}_{2}, \mathrm{CO}$, and water. If the space above the melt is reducing, organic compounds will pyrolyze and can be later combusted in a separate 
afterburner section of the offgas system. If the melt is oxidizing, metals will oxidize and become part of a slag; this process could take longer than would be practical, however, especially in a low temperature melter where reaction kinetics are slow. If the melt is reducing, separate metal phases can form below the slag. Some metals are more resistant to oxidation than others. Aluminum and the reactive metals such as titanium and zirconium are readily oxidized and will remain oxidized even in a reducing melt. They will therefore partition into the slag. TRU elements will also be oxidized, even in a reducing melt; however, there is some concern regarding the possibility of vaporization of plutonium oxyhydroxides that have high vapor pressure and may result as an intermediate product of $\mathrm{Pu}$ melt/dissolution with organics present. Iron, cobalt, and nickel will be in the metallic state in a reducing melt, and form a separate phase. Depending on residence time and the availability of oxygen, pyrolysis and/or oxidation of organic materials takes place above the melt. Arc- and jouleheated melters using carbon electrodes must avoid an excessively oxidizing environment near the electrodes or excessive electrode corrosion/oxidation will result. An acceptable guide for achieving sufficient breakdown of finely dispersed organics is 2 seconds at $1000^{\circ} \mathrm{C}$.

Process Throughput. The amount of materials that can be processed by a melter depends on the following:

- Power level

- Heat losses

- Water content of the feed

- Organic content of the feed

- Redox in and above bath

- Flux additions.

At $100 \%$ energy transfer efficiency, an electrical heating method will heat one metric ton of aluminum silicate to $1650^{\circ} \mathrm{C}$ in one hour using $430 \mathrm{~kW}$. A reasonably efficient electric melter should use $80 \%$ of the electrical energy for heating of the charge. If the charge contains $20 \%$ water, which must be evaporated, the energy requirement goes to $650 \mathrm{kWh}$ per metric ton; at $80 \%--812 \mathrm{kWh}$ per metric ton. Large pyrometallurgical furnaces have power levels up to $80 \mathrm{MW} ; 20-30 \mathrm{MW}$ units are common (the FMC phosphorous plant in Pocatello, ID, has three, $25 \mathrm{MW}$ units). Because larger units may be difficult to seal, a $5 \mathrm{MW}$ unit is assumed. The throughput of a $5 \mathrm{MW}$ unit should be 6 metric tons per hour. Pyrolization of organics will absorb energy (endothermic), while oxidation of organics above the bath will release energy (exothermic). Variations in the water and organic content of the feed and the redox condition in the melter therefore affect the throughput.

Cold Cap (Burden). A cold cap or burden is obtained by loading the charge on top of the melt and allowing the heat to melt the charge. New material is continually added as the bottom material melts or evaporates. In order for this strategy to be successful the burden must be kept porous to allow gases to escape. This technique is common in the following metallurgical shaft furnaces: blast furnaces, cupolas, and ferroalloy electric arc furnaces. Westinghouse and Scorpion have reported considerable problems with plugging of the burden in their shaft furnaces while treating waste. Cold 
caps have been successfully applied in joule melters where the cold cap traps volatile material and returns it to the glass melt.

Freeze Wall or Skull. A freeze wall or skull (see Figure 7) is used when the molten material is too corrosive or too hot to be contained by a refractory. By removing heat at a sufficient rate from the molten material through the container wall (crucible), a layer of frozen melt can be interposed between the lining of the furnace and the molten material. Thus, the molten material is contained in a crucible composed of itself, and attack is no longer a problem. Water cooling of the outer wall of the furnace is generally used to remove the heat. Skull thickness is controlled by the rate of heat removal, the thermal conductivity of the frozen slag, and the rate of heat transfer from the melt to the skull.

Feed Systems. A feed system must include hardware to receive the waste package (TRU contaminated), the enclosures (airlocks) and mechanisms to transport the package to a pretreatment area (which will be highly contaminated because the waste packages are opened there), the equipment to pretreat the waste (open the containers, size the containers and its contents, sort, mix, repackage, etc.), and the actual mechanism that transports the pretreated waste into the processor (melters, incinerators, roasters, etc.).

Any feed system for this application must be totally enclosed, similar to airlocks in an alpha handling facility. This requires that waste containers arrive to the feed system intact with no surface contamination and that they be opened and pretreated in a confined and controlled enclosure. For production-type activities this probably will require automated type operations and minimal hands-on handling. The equipment used to perform these activities should be of proven design, modular in concept, easily maintained, easily decontaminated, and highly reliable. It would be ideal if all the equipment were small enough to fir in a glovebox enclosure to allow hands-on cleaning and repair whenever necessary. Pretreated waste may be repackaged into a disposable container for transfer to the processor to meet the confinement requirements of an alpha handling facility.

The necessary types of activities to be performed on the waste prior to processing will be dictated by the capabilities and constraints of the processor selected. However, no matter what processor is selected, all waste will be delivered through a series of airlocks to prevent the spread of contamination, isolate the furnace internal environment from the fest system, and minimize the perturbations to the furnace. The major questions (from a processing standpoint) that determine the selection of feed system components are how much sizing is required, how much sorting is required, how much mixing is required, and how much material needs to be processed."

Slag Handling Systems. Until the final waste form is cooled and sealed in its final storage container, it must be confined in the slag handling system to prevent the potential spread of contamination even though the alpha contaminant is assumed to be dissolved in the slag. Tapping 


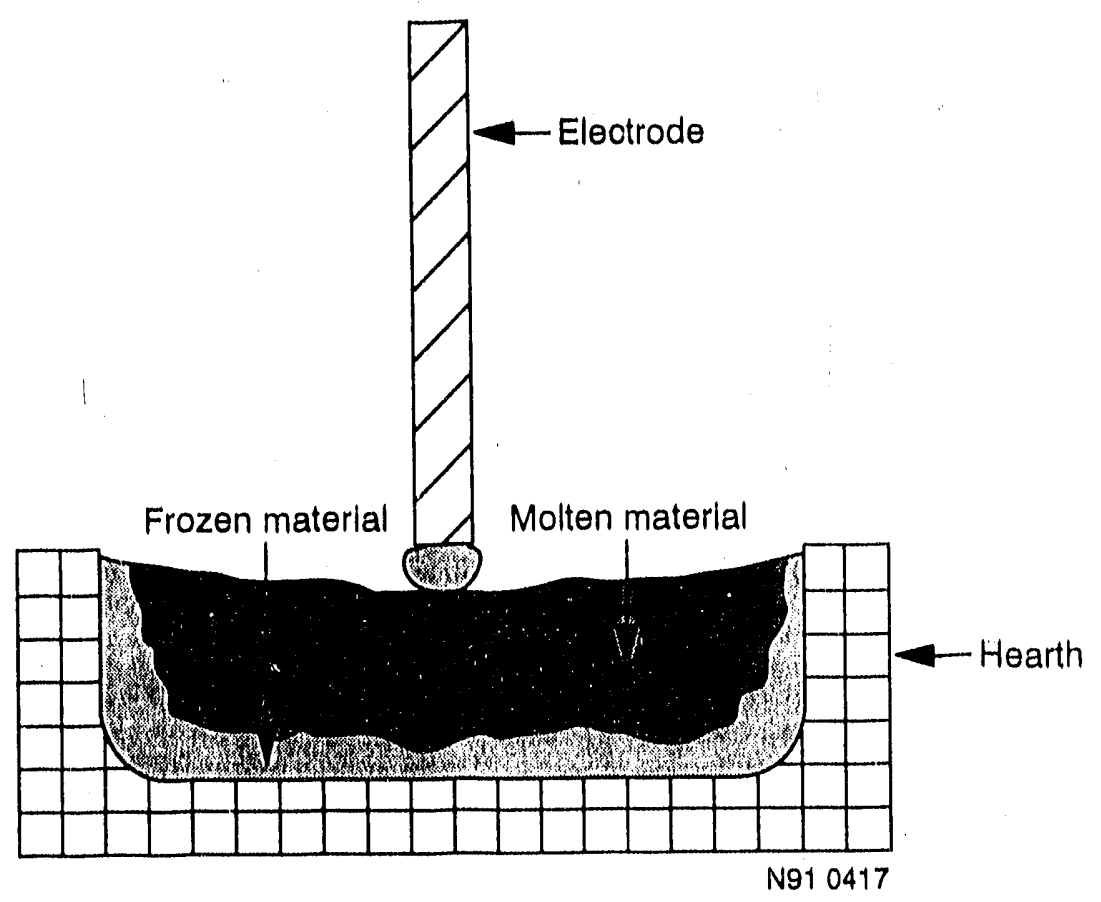

Figure 7. Freeze wall or skull melt. 
or continuous pouring from a furnace is done remotely and automatically in the steel and glass industry, but in our case the operation needs to be totally confined. Spills will not be allowed and control of the pour is eritical. On-line sampling techniques are available but reliable assaying techniques are not. The slag handling system includes all components necessary to remove the slag from the furnace, containerize it, cool it, and deliver the final package to the shipping dock. Like the feed system it would be ideal if the components were small enough to fit in a glovebox enclosure to facilitate cleanup and maintenance. After cooling, repackaging and passage through a series of airlocks to the outside may be possible.

The actual process will determine the final characteristics of the slag output but samples for the verification and demonstration of those properties will be gathered in the slag handling system. Means for determining and handling an unacceptable final product must be provided.

Offgas Treatment. A method for removal of particulates will be required in all cases. The type of system will not vary with the process selected but its size will. If there is no combustion of the volatile species in the primary reactor proposed (the gaseous environment is reducing), and the input waste stream is identical, the effluents generated from the various processes will generally be the same except for variance in the quantitics. However, some processes may inherently allow more high vapor pressure metals to escape or allow greater entrainment of particulates.

Low-temperature joule-heated melters (JHM) operated with a cold cap will release few volatile metals to the offgas treatment system; whereas, a high-temperature system employing a JHM (or a plasma torch) has been indicated to only partially retain volatiles, such as cesium. Particulate control requirements are based on how aggressive the furnace environment is. The gases are pulled from the primary reactor and through the offgas treatment system by an induced draft fan set to always maintain a negative pressure in the primary reactor. The quiet upper chamber area of a JHM or PHM operating with a cold cap will retain most of the particulate and eventually incorporate them in the melt. Plasma-heated units can be more turbulent, depending on the operating mode. The turbulent environment will tend to drive off particulate generated, but it will also provide better mixing for oxidation. In the Retech Plasma Centrifugal Reactor experiment ${ }^{\text {b }}$ at INEL/MSE in Butte, MT, the transferred-are plasma-torch gas acts as an air lance for oxidation of organics and metals and enhanced dissolution of metal oxides in the melt, thus reducing required slag residence time in the melter.

In all cases, the gases need to be cooled prior to filtering and this can be accomplished with a wet scrubber that will also neutralize the gas and remove some of the particulate. The gases will be

b. Personal communication with Steve Kujawa, INEL/MSE CDIF, September 1991. 
further treated in a venturi scrubber to remove as much of the remaining particulate as possible and then sent through a demister to remove water vapor; then the gases will be heated to put any remaining water into the gaseous state before final filtering through the HEPA filters (to remove radioactive particles). The gases can now be released up the stack. Reference 12 provides a detailed survey of offgas technology and considers applications for a typical incinerator and melter.

Instrumentation. Basic control instrumentation and control systems to monitor and control the melter processes evaluated exist, however, it is anticipated that additional instrumentation beyond that normally required in commercial applications will be necessary. The techniques for on-line assaying at production processing rates are still in development. An integrated system will require demonstration. 


\section{DEVELOPER AND VENDOR ASSESSMENT}

\subsection{Vendor Information}

Technology developers and vendors in both joule-heated and plasma/arc melting were surveyed to establish both the state of the art and the development needs of the technologies for application to SDA waste at the INEL. The organizations listed in Table 1 possess or are developing technology for processing waste by melting. A brief review of their activities appears in this section. More extensive descriptions are included in the directory forms in Appendix A. Developers and vendors were visited in order to see equipment and processes first hand and to have detailed discussions on the theory and operation of the technologies. Literature reviews supplemented the visits. Comparison of the various technologies was extremely valuable in identifying limitations, identifying areas of common technological concern and distinguishing between s()-called solutions and potential problem areas.

An information form was developed and filled out for each developer/vendor. In some cases, the developer/vendor filled out the form and additions were made by INEL personnel. In other cases, the form was filled out by INEL personnel after a facility visit with additional information gathered by FAX or telephone interchange. This information form is included in the directories in the appendix. The questionnaire was used a guide, but did not limit the information gathered. Detailed information and critical assessments conclusions are contained in both the report and the forms. Additional information is available in the bibliography files generated. Comparisons and conclusions of applicability and development needs of developer/vendor technologies are presented later in this report.

The organizations visited by INEL personnel are indicated in Table 1. The objectives were to discuss the processing of the buried waste first hand, initially assess the organizations capability to participate in the project, and evaluate personnel, components, and systems.

\subsection{Joule-Heated Melters}

\subsubsection{Overview}

Joule-heated melters are heated hy passing an electric current through a conductive liquid slag or glass. Immersed electrodes are used, although there is interest in using short ares to deliver the current to the melt. Arc/plasina melters, however, also have a joule component to the heating as the current path is from the are attachment at the melt surface through the melt to the return electrode. The relative distribution of the radiant and convective heating is a function of the voltage drop in the 


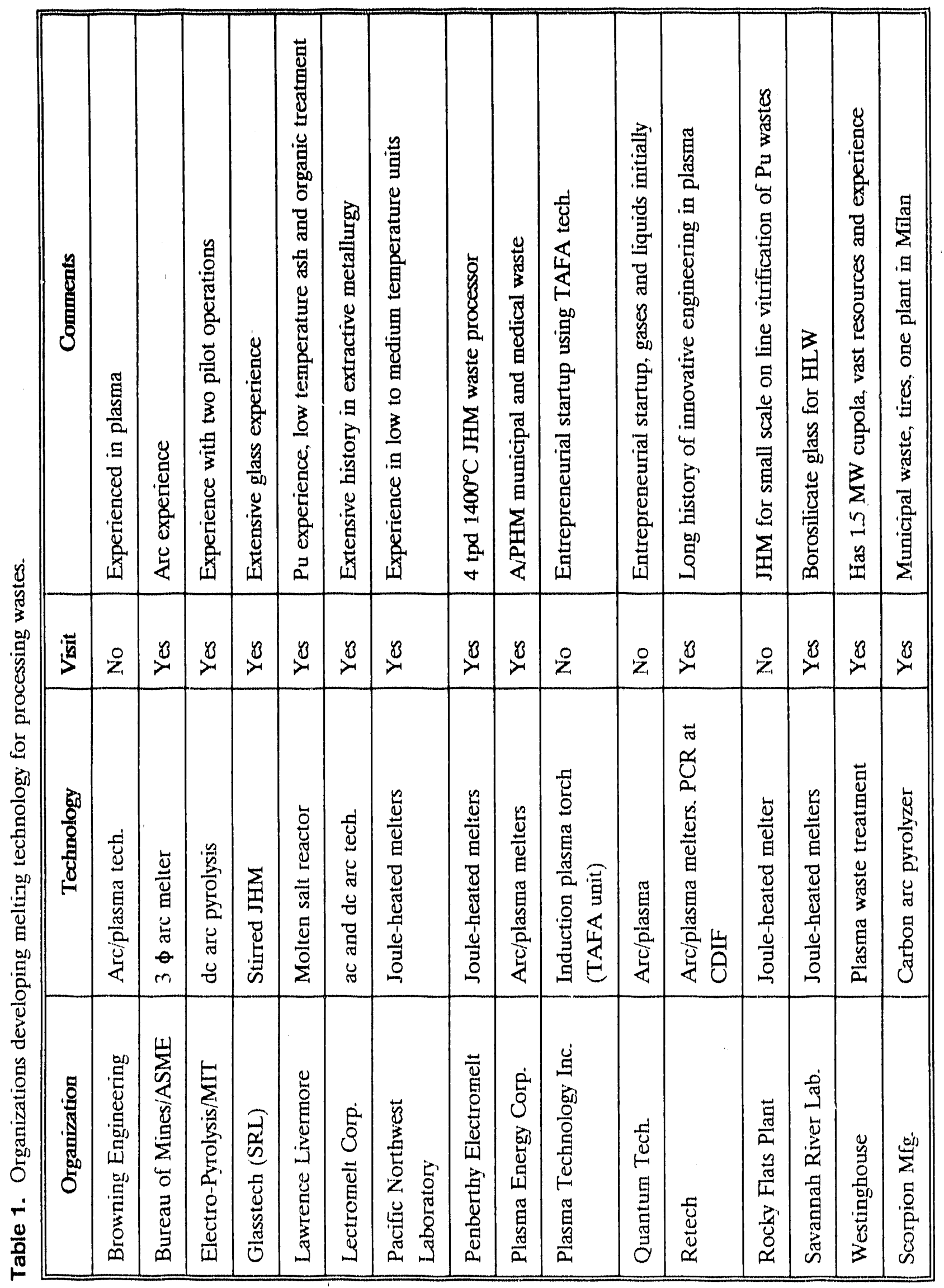


are vs, the voltage drop in the melt. Immersed electrodes are limited in temperature by the ability of the electrode material to resist eorresive attack or melting. Inconel electrodes, which are very resistant to oxidation, have a temperature limit of about $1150^{\circ} \mathrm{C}$. Fluxes would therefore be required to melt basalt and many metals would not melt in the relatively cold bath, instead forming a low resistance path for the current. Low molting point metals, such as aluminum, would form a molten pool under the melted slag (known as a salamander), which would also create a low resistance path. Carbon or molybdenum electrodes can be used to melt basalt but are easily oxidized. Unstirred melters are characterized by large size and long residence times (24 hours or more); stirred melters can be much smaller. Glass melters throughput is controlled by the surface area: unstirred melters require $4 \mathrm{ft}^{2}$ per ton per day; stirred melter require $0.5 \mathrm{ft}^{2}$ per ton per day.

\subsubsection{National Laboratory Development of JHM Technology}

Pacific Northwest Laboratory has been developing JHM technology for 20 years. Most of their experience has been with melters with Inconel and molybdenum electrodes; however, PNL has recently designed a high-temperature device for Recomp, a municipal waste incinerator, for the melting of incinerator ash. The design operating temperature $\left(137()^{\circ} \mathrm{C}\right)$ is intended to be reached using either carbon or molybdenum electrodes.

PNL pionecred the development of the joule-heated, ceramic lined glass process for immobilizing high-level radioactive wastes. Since 1973, their focus has been on high-level waste but in the past five years they have expanded their efforts to include other waste streams.

The PNL unit is a refractory lined reactor in which a pooi of glass is initially melted by auxiliary heating and maintained in a molten state by joule heating obtained by passing a current between electrodes immersed in the glass. The resistance of the glass to the flow of electrical current creates the needed rise in temperature. Normal operation for this unit is at $\leq 130()^{\circ} \mathrm{C}\left(24(K)^{\circ} \mathrm{F}\right)$ and slightly negative pressure. Electrodes are of molybdenum, inserted from the top of the furnace, and are adjustable.

Waste is pretreated and fed to the unit in a liquid slurry or calcined form. Volatile constituents of the waste stream are eombusted in the head space chamber volume above the molten glass pool. Combustion air is supplied through ports in the sides of the combustor. Auxiliary heaters are used to maintain heat in the space above the melt and to ensure combustion of the volatiles. However; the top can be kept cool allowing a cold cap to form thereby capturing any volatilized heavy metals eventually encapsulating them in the melt. The volatile offgases would then be combusted in a separate specially designed unit.

Savannah River Laboratory has developed a process for vitrifying HLW using borosilicate glass that operates at $11500^{\circ} \mathrm{C}$. SRL is collaborating with Glasstech in Toledo, Ohio, to develop a stirred meller using lnconcl electrodes. 
Rocky Flats Plant has designed and nearly completed a small JHM for the treatment of TRU and LLW. Unit size was kept small to absolutely prevent criticality problems with the design waste strcams: TRU organic sludge and LLW nitrate salts. Electrodes are Inconel 69), so temperature is limited to $11500^{\circ} \mathrm{C}$. Novel nonmechanical stirring methods are utilized. As designed, this unit is not suilable for heterogeneous SDA waste.

\subsubsection{Commercial Development of JHM Technology}

Glasstech $^{13}$ has developed a commercial line of stirred melters for waste processing. They have developed state of the art glass bending and heat treating technologies that are prevalent in the automobile and architectural fields worldwide. Glasstech collaborates extensively with SRL. Two sizes of stirred melter have been designed: $110 \mathrm{lb} / \mathrm{hr}$ and $228 \mathrm{lb} / \mathrm{hr}$. Because the stirrer and container aro both Inconel 69), they are limited to $1150^{\circ} \mathrm{C}$.

Penberthy Electromelt ${ }^{14}$ has developed a JHM (with Mo electrodes) that operates at $1260^{\circ} \mathrm{C}$ ( $\mathrm{sec}$ Figure 8). This furnace has processed 5000 drums of RCRA waste. Penberthy is a small company in Sieattle that has done innovative work in the joule-heated melter area for many years. They do not have the resources to do extensive development on their own, so they are secking partners for further development.

\subsection{Arc/Plasma Furnaces}

\subsubsection{Overview}

A plasma is a highly ionized gas created by passing a selected gas through a strong electric field. Electrons are stripped from the gas molecules and when these electrons are recombined with the ionized species, a significant amount of energy is released. Temperature in the plasma can be on the orcler of $10,0(0) \mathrm{K}$. Arc/plasma technology has been used in the metals smclting and refining industry for many years and is being considered for use in wood gasification, glass manufacturing, and now in miked waste processing. Arc/plasma provides a very high energy density heal source and in the case of the plasma torch the potential for inlluencing process chemistry via the torch gas utilized.

In general, are/plasma melters do not have significant heat source temperature limitations; which enables them to melt basaltic soil without utilizing addition of fluxes such as sodium or potassium. Are melters use carbon electrodes $t o$ are directly to the melt. Although they produce a plasma in the vicinity of the are they do not require plasma gas to operate: they will not operate well (electrode oxidation) with a high oxidizing gas potential around the carbon electrodes, although oxygen can be injected into the melt to oxidize carbon and metals without causing electrode problems. Therefore, aro melters may need to be operated as plenum pyrolyzers for organics, although there are schemes to protect clectrodes from oxidation. Plasma (torch) melters use water eooled copper electrodes (usually), require plasma gas, can operate with a highly oxidizing environment around the electrode(s), and can be operated as oxidizers or pyrolyzers. 


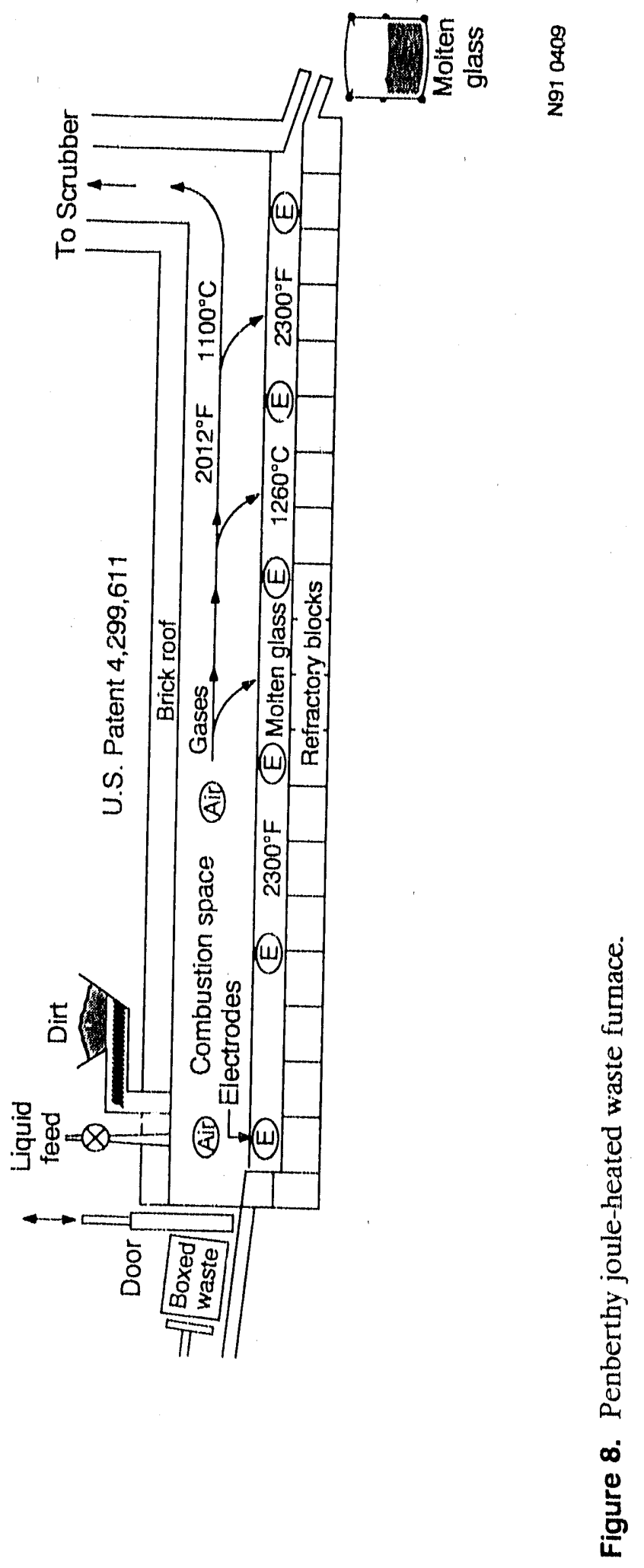


Arc/plasma heating systems offer a controlled, concentrated, high inlensity and rellable heat source that can burn the combustible portion and melt the noncombustible portion of the INEL buried mixed waste. The heating system includes the power supply, water cooling equipment, gas supply, and the arc/plasma torch. The arc/plasma torch converts the electrical energy into sensible heat by producing hot ionized gas in a controlled are discharge. Torches can operate over a wide range of pressures with a variety of gases and gas mixtures (or no gas in the case of graphite electrodes) including oxygen, argon, helium, hydrogen, carbon dioxide, or methane. This flexibility means the furnace atmosphere is variable and can be tailored to satisty the individual processing environment. Water cooled plasma torches use a significantly lower volume of gas than the air or oxygen volumes needed by fossil fuel heaters, thereby reducing the size of the off-gas equipment required. Torches can be sized to deliver from $50 \mathrm{~kW}$ to as high as $6,000 \mathrm{~kW}$ and can be of the transferred arc or nontransferred arc configuration. In transferred arc operation with water cooled torches, one electrode is an integral part of the torch and the molten bath acts as the second electrode to conduct the electric power. With graphite electrodes, the arc is always transferred. Heat transfer occurs from induced convection by the plasma gas, direct radiation from the arc/plasma, reradiation from the surrounding refractory, and joule heating from the current flow through the melt. A nontransferred torch contains two internal electrodes with the injected gas creating the plasma flame that impinges on the melt and depends on plasma gas conduction/convection and radiation to transfer heat to the melt. They produce temperatures in the plasma zone well beyond those possible with fossil fuel burners, in the neighborhood of $10,000 \mathrm{~K}$ or higher making it possible to easily achieve melt temperatures needed to process the basaltic soil and metals found in the INEL waste. The thermal efficiency of the torch itself consistently reaches between 50 and $85 \%$ giving higher temperatures for faster and more complete reactior kinetics; aiding in the destruction of hazardous organic constituents. Torches may use ac or de current, but de operation requires the torch be set as the anode or cathode. Electrode life is a key design consideration. Existing torches have mean lifetimes of approximately 200 hours, although 500 hours can be achieved through derating operation.

\subsubsection{Technical Basis for Design of Arc/Plasma Melters}

Arc/plasma technology has a long history; carbon are melters were in use a lew years after high power electrical generation was possible in the last half of the nineteenth century. Rapid evolutionary change in the design of arc furnaces for steel melting has laken place in the last 10 years: power densities have risen through the extensive use of water cooled panels, and the three electrode ac are furnace is giving way to the single electrode de are furnace. Users and builders of arc furnaces collaborate on the experimentation and design of new approaches. Improvements are driven by the need of a large number of very competitive companies attempting to take the technical high ground. This type of competition leads to rapid evolutionary improvement in the design and operation of technical equipment.

New Yorker magazine published an excellent review' of the startup and initial operational problems associated with a steel are melter at the Nucor Crawfordsville plant. ${ }^{15}$ Extensive information on the design of stecl are melters is contained in the Electric Furnace Proceedings. ${ }^{16}$ Technical experts who 
understand design requirements for arc slag smelters are increasingly rare because the U.S. smelting industry is disappearing. Plasma melters that use water cooled plasma torches instead of carbon electrodes have a different history. Plasma technology grew out of the National Aeronautic and Space Administration (NASA) need for high-temperature reentry simulators and the reactive and refractory metals business which required extremely clean melting furnaces. The torch used in the Retech PCR is the same torch used in their aerospace titanium/superalloy superclean melting furnaces, which are all stainless steel with no refractory material in the furnace.

At least two developers are working on adapting high-powered induction plasma devices to the treatment of waste. Past limitations of poor electrical efficiency in the conversion equipment have been overcome. Efficiencies are up to 70 to $80 \%$ as contrasted with $50 \%$ a few years ago. These units are basically gas heaters in which the heated blast would be used to heat the waste.

\subsubsection{National Laboratory Development of PHM Technology}

Sandia National Laboratory (SNL) has been doing extensive development on vacuum arc remelting (VAR) for many years. VAR technology uses a consumable electrode of the material to be melted. VAR is not directly applicable to the treatment of waste; however the basic understanding being developed could be very important for the deveiopment of waste processes.

\subsubsection{Commercial Arc/Plasma Technology Developers}

Retech Inc. of Ukiah, California has extensive experience in designing and manufacturing equipment for the production of vacuum metals using plasma arc technology. Using this background they have developed a plasma centrifugal furnace (see Figure 9) for treating solid hazardous wastes. ${ }^{9}$ The system is being tested at the INEL Component Development and Integration Facility (CDIF) in Butte, Montana with funding from the Department of Energy (DOE) and the Environmental Protection Agency (EPA).

The system is designed to incinerate organic components and immobilize oxidized, inorganic components in a glassy slag. The system uses a transferred arc torch to heat the waste in an enclosed rotating drum. Torch angle can be adjusted both vertically and radially to maximize the efficiency of the process. The rotating drum has a copper throat upon which the plasma torch initially arcs. A solidified layer of slag or skull that remains from previous runs begins to melt and becomes a conducting medium. Once the surface of the skull becomes tacky, waste can be fed at a controlled rate. Waste is fed to the refractory lined rotating drum by a screw feeder sized to handle basically soils and sludges. Retech has a feed system that can handle full drums, opening them inside the unit and discharging the contents into the rotating hearth (tub). The waste is retained against the bottom and side of the tub away from the pour hole by the centrifugal action of rotation at $25-40 \mathrm{rpm}$ and is maintained there for sufficient time to allow the $500 \mathrm{~kW}$ torch to melt the inerts. The less volatile metals are trapped in the slag and the gaseous products combusted in a secondary chamber. The molten slag is removed from the unit by slowing the rotation of the tub allowing gravity to pull the 
slag through a center tap into a mold located in a sealed chamber below the secondary chamber. When full, the process is stopped and the mold is removed.

The use of air plasma and pure oxygen in the primary chamber and additional oxygen in the secondary chamber results in complete combustion and very low offgas volumes. The offgas is drawn, by an induced draft fan, through an off gas treatment system consisting of a quench tank, jet scrubber, packed bed scrubber, and a demister. The entire system is maintained under negative pressure; the offgases are cooled and neutralized in the quench tank, and the jet scrubber removes particulates in the gas stream, further reducing their temperature. The gases are then introduced to the packed bed scrubber as a backup to the quench tank and the jet scrubber. The demister removes any remaining water droplets from the gas stream.

The system is continuously monitored for emission of carbon monoxide, carbon dioxide, oxygen, sulfur dioxide, nitrogen oxides, hydrogen, and total hydrocarbons. In addition, stack sampling is conducted as per the appropriate EPA sampling methods.

Retech has two experimental units located at its manufacturing location in Ukiah, California. One is a smaller unit that was used to develop the centrifugal reactor concept. The other is a simple melter that was put together for SAIC test melts of Rocky Flats compacted waste. The smaller unit uses a $75 \mathrm{~kW}$ water cooled torch. The larger unit uses a $600 \mathrm{~kW}$ torch.

Electro-Pyrolysis, Inc. (EPI) has been in business as a company for over nine years and is currently developing dc graphite arc technology that could have application for the treatment of INEL buried waste. In 1987, a plasma arc facility with capability exceeding $1 \mathrm{MW}$ was built and operated at Model Cities, New York with funding provided by the Electric Power Research Institute (EPRI). ${ }^{17}$ Recently, a smaller unit designed for operation in the $100-500 \mathrm{~kW}$ range was tested in Niagara Falls, New York.

The use of $\mathrm{dc}$ graphite electrode plasma arc technology provides a high-temperature environment with uniform heating resulting in reduction of the noncombustible components of the waste to a stable, nonleachable form. In addition, it produces relatively low off-gas volumes and pyrolytic destruction of hazardous organic constituents thereby significantly reducing the size of the off gas treatment system.

A potential furnace candidate designed and built by EPI (see Figure 10) uses a single hollow graphite electrode (centered in the furnace) that forces the furnace gas up through the electrode center before entering a scrubber. This ensures that all the gas is subjected to the high-temperature $\mathrm{dc}$ arc zone before leaving the furnace. The low volume of gas produced keeps the gas velocities sufficiently low so that the amount of particulate exiting the furnace is much less than a comparable system with an agitated atmosphere. There is a capacity to trap volatilized material by condensing on the particles above the molten bath. The introduction of external gas is not required. The production of $\mathrm{NO}_{\mathrm{x}}$ is reduced by sealing the system to air infiltration. The furnace operates under 


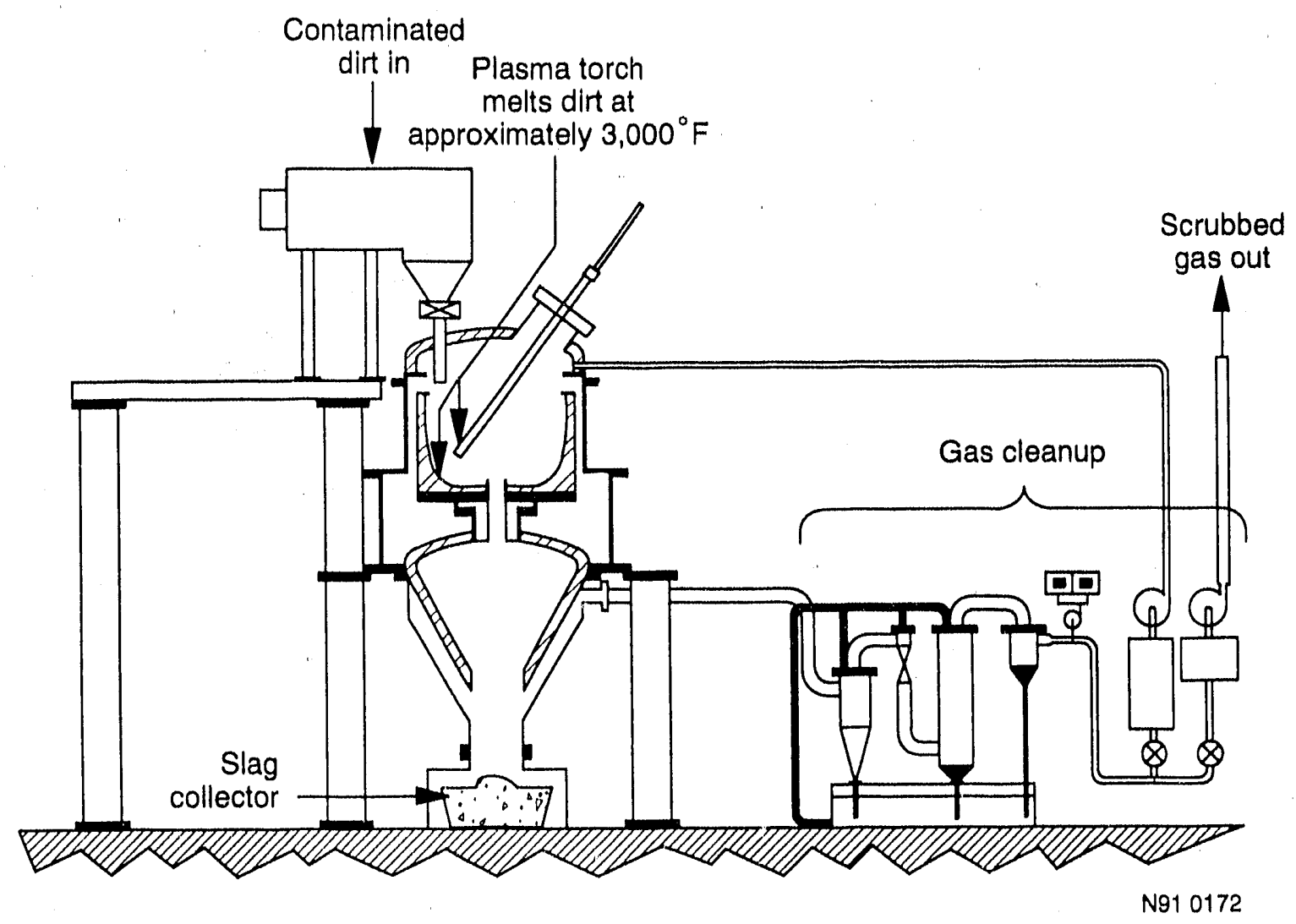

Figure 9. Retech plasma centrifugal reactor. 


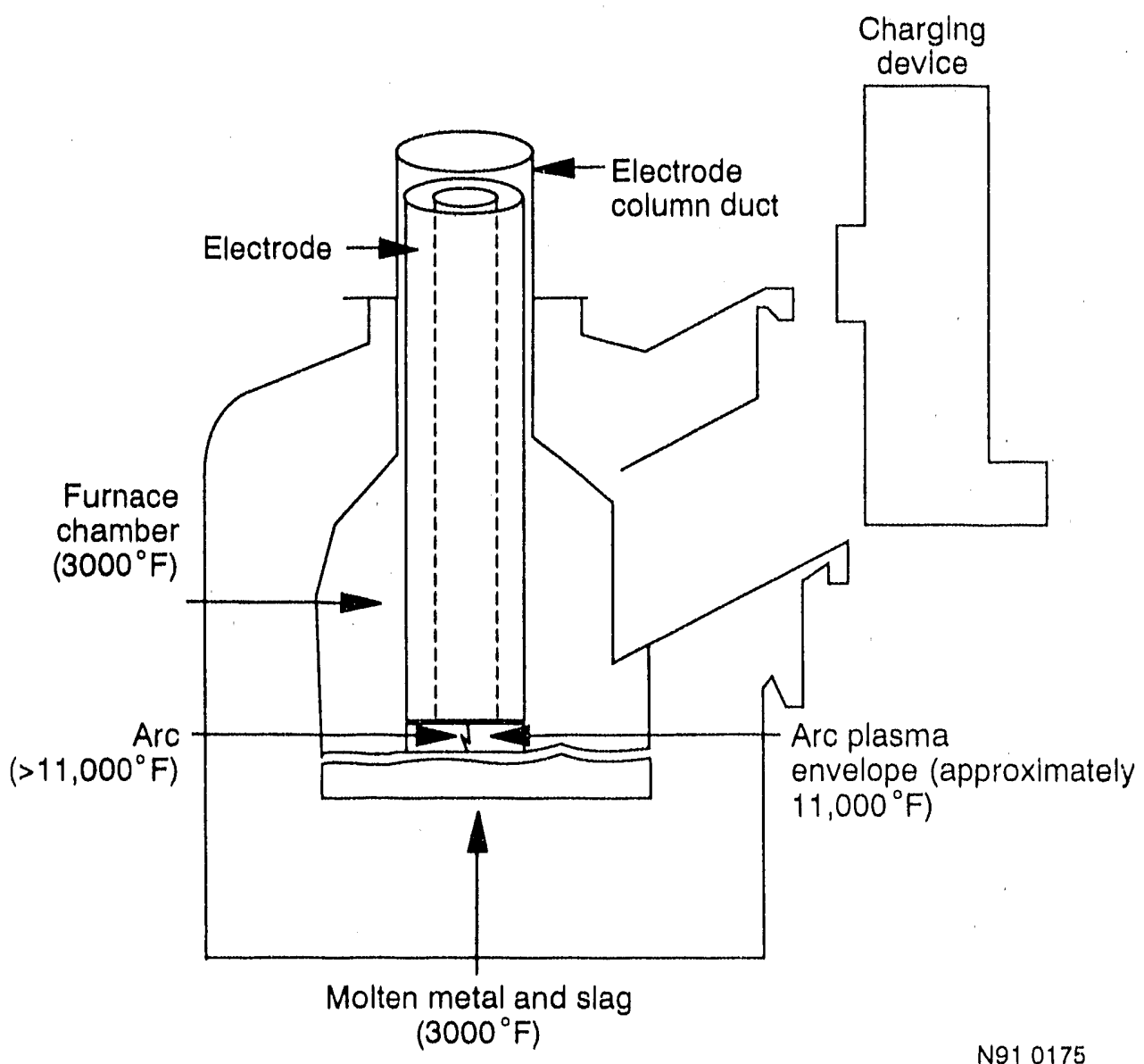

Figure 10. Electropyrolysis, Inc. furnace. 
a positive pressure of approximately 3 psi but could be operated under a negative pressure according to the designers.

The use of a de arc, struck between the electrode and the molten material, is much quieter than either a single phase or three phase ac arc. This also means less gas agitation and less particulate carryover. One centralized dc arc permits better control of the arc by keeping it from migrating to the furnace lining in a localized area near the melt line, and providing longer refractory life in this critical area of the furnace. The electrode life in the $1 \mathrm{MW}$ unit is estimated to be in the thousands of hours, which is significantly longer than that of the water cooled, metal electrodes in a plasma torch. There is no possibility of injecting a high pressure stream of water onto the molten bath with this configuration because the electrode is water cooled only at the metal-graphite junction.

The furnace shell is normally protected only by a refractory lining but water cooled panels can be employed as the furnace shell, which will form a skull to insulate the unit. This assumption is contingent on the fact that the material being processed produces enough of a residue with the right properties to form and retain a skull. Materials of construction are standard structural grades of carbon steel with no use of exotic material required.

In this system, waste is fed to the furnace through a series of two chambers that are separated from each other and the furnace by slide valves. Waste is placed in the outer chamber. The outer door closes and activates a switch that signals the intermediate door to open, and the waste is transferred to the inner chamber, the intermediate door closes, activating a switch to open the inner door to the furnace. This concept is much like that used for transfer of material in an alpha handling facility apart from regulation of the air llow in the transfer chambers such that the flow is always from the area of no contamination to the area of highest contamination. However, this method minimizes the undesirable introduction of air to the furnace, and prevents release of untreated furnace gases to the atmosphere. Molten metal and slag produced in the furnace is tapped using conventional steel mill tapping methods.

The offgas is treated in a wet scrubber, which cools and neutralizes the gas and removes the particulate. If the gas stream contains hydrogen and carbon monoxide it is burned in a ground-level flare.

By the end of 1991, Electro-Pyrolysis/MIT expect to have a unit of about $200 \mathrm{~kW}$ on stream that uses both a carbon electrode and a carbon crucible to contain the melt.

Plasma Energy Corporation (PEC), a subsidiary of First Mississippi Corp., is a major manufacturer and supplier of plasma heating systems for commercial and research applications. In collaboration with an international producer of vacuum process engineering, they have developed torches for processing metals in high purity environments. The business strategy of First Mississippi is do initial development of a process at PEC, then when the potential looks promising, to spin off the business 
into a new subsidiary. First Mississippi has the financial resources to develop a major business; however, they are unwilling to devote extensive resources to a new technology until the potential is evident. They are not likely to develop a plasma treatment system without extensive support.

PEC is currently planning to rebuild their obsolete test laboratory facility for operation again in the summer of 1992.

In 1990, PEC melted $400 \mathrm{lbs}$ of RWMC soil in a hearth type melter in Raleigh using a $400 \mathrm{~kW}$ water cooled transferred arc torch ${ }^{18}$ and excellent vitrification was obtained. The general layout of a hearth type plasma melter is shown in Figure 11.

Lectromelt has a $50 \mathrm{Kw}$ lab test melter that uses single phase ac with two carbon electrodes. They have an extensive history of developing and building arc melters for the metallurgical industry. J. Kevin Cotchen, their technical director, and Howard F. Davis, their retired technical director, recently wrote a paper titled "Electric Arc Furnace Processing of Solid Wastes." In the paper they discuss the processing of HVPM and sewage sludge. Lectromelt has generally built three phase ac arc furnaces for the processing of ores and slags. Materials processed include iron ore briquettes, phosphorous, lead, zinc, chrome, baghouse dust, copper, silver, silicon, nickel, and ferroalloys. The general features of several arc melters are shown in Figures 12, 13, 14, and 15. , Power levels up to $105 \mathrm{MW}$ have been built, capable of melting 130 metric tons per hour of basalt. Sealing technology for the production of phosphorous (which is produced as a gas) is well developed; however, this will probably only be a starting point for sealing of TRU. Lectromelt built the furnace used by Electro-Pyrolysis for the Model City Project. The general features of this device are shown in Figure 10.

Bureau of Mines/ASME. The Bureau of Mines and the American Society of Mechanical Engineers (ASME) have recently constructed a 1.5 MVA 3-phase carbon electrode arc melter for use in developing a process for vitrifying municipal incinerator waste ash. Lectromelt Corp. designed this state-of-the-art melter to be air tight to prevent the escape of hazardous fugitive gases. Figure 14 shows a similar, but larger, furnace.

Westinghouse has the plasma assisted cupola that was used to develop plasma assisted cast iron melting. ${ }^{6}$ The general features of this device are shown in Figure 16. Experimental treatment of PCB contaminated soils from the Westinghouse Bloomington, Indiana, transformer plant has been done in this unit. It will be back on stream early in 1992. Westinghouse has had bridging problems in the treatment of contaminated soils; when the shaft begins to plug up it is necessary to respond immediately if the total plugging is to be prevented. ${ }^{1}$

c. J. K. Cotchen and H. F. Davis, Electric Arc Furnace Processing of Solid Wastes, Paper submitted for International Symposium on Processing of Residues and Effluents, San Diego, CA, March 1-5, 1992. 


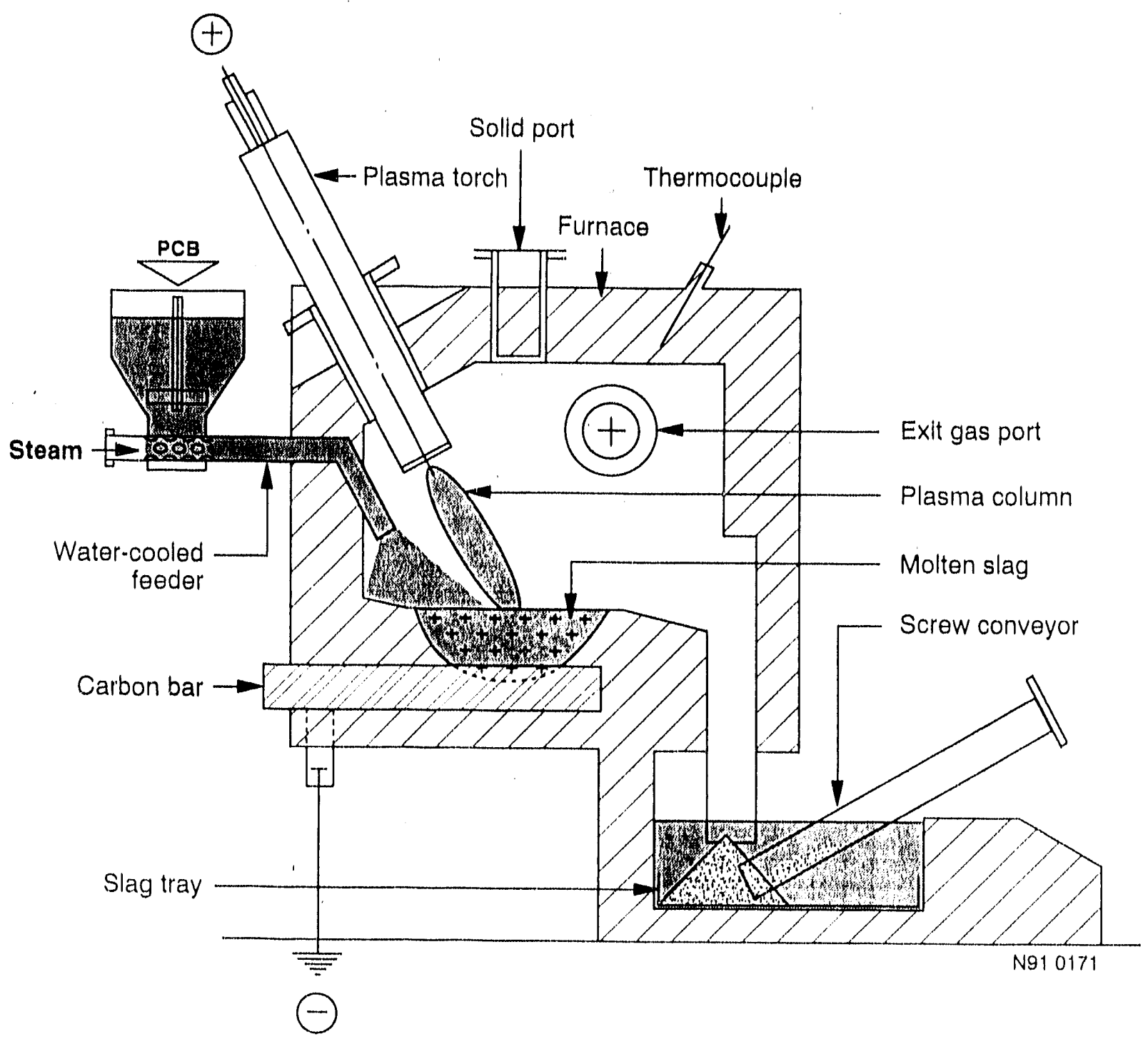

Figure 11. Plasma Energy Corp. hearth furnace. 


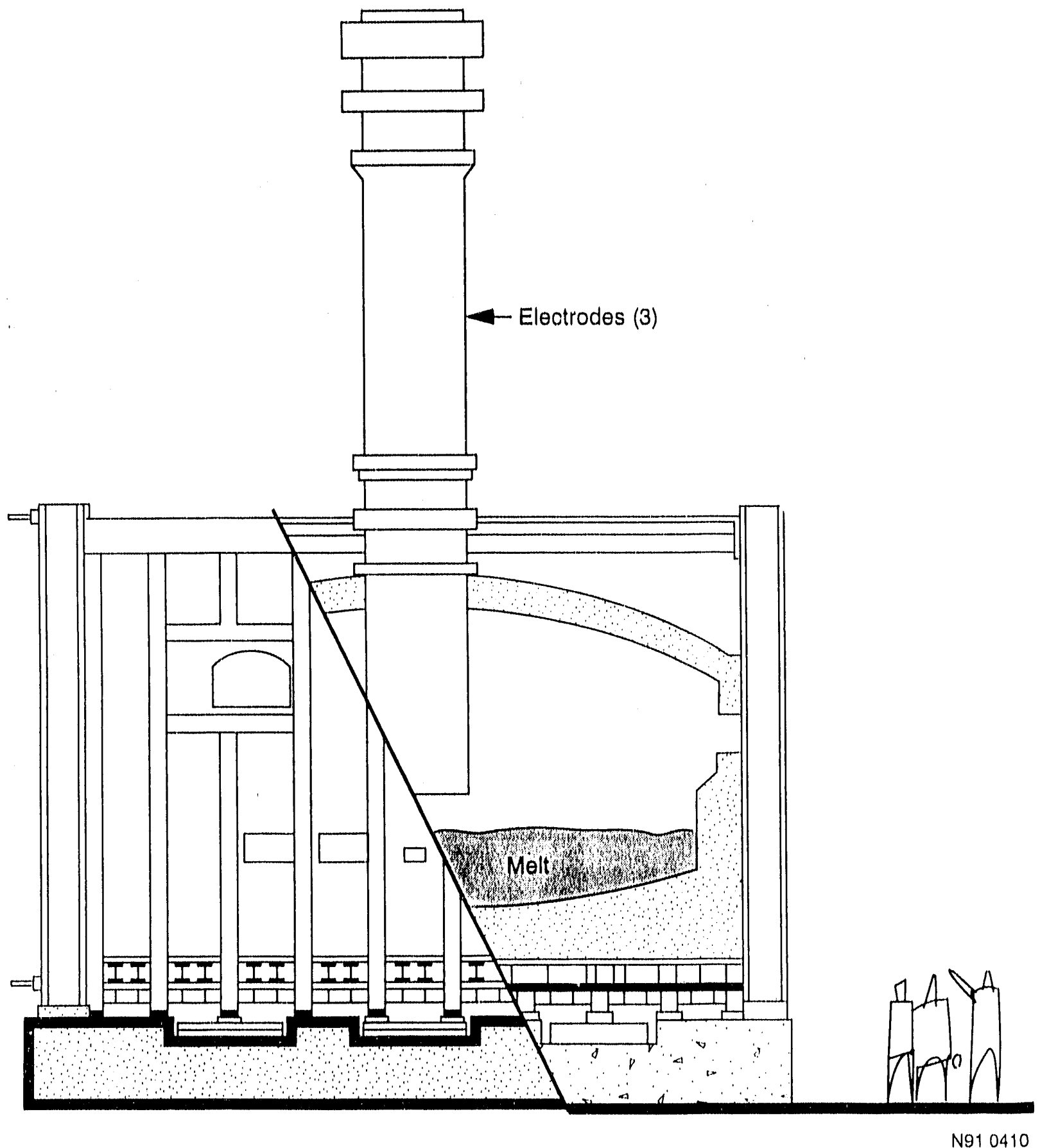

Figure 12. Lectromelt $36 \mathrm{MVA}$ copper matte furnace. 


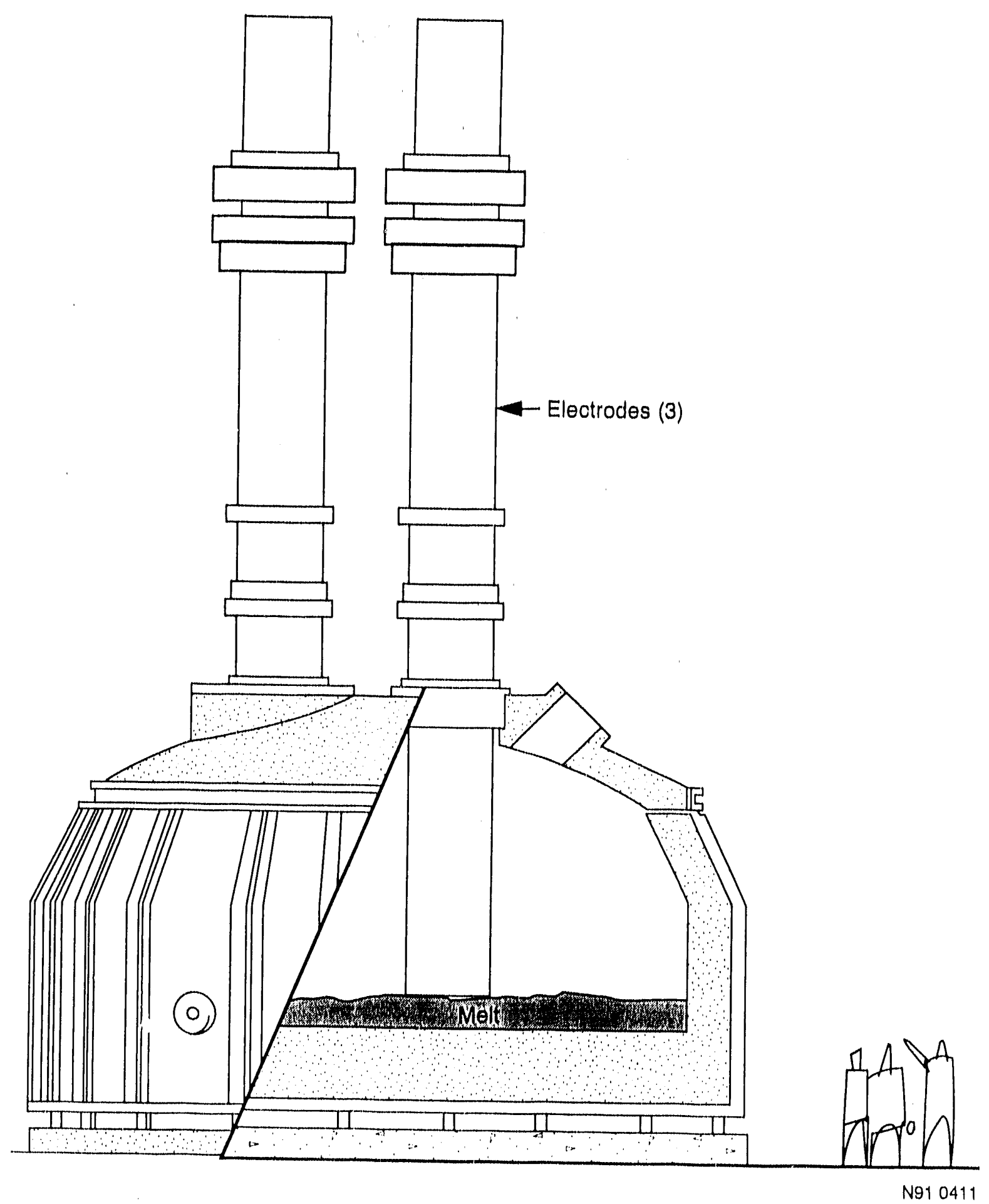

Figure 13. Lectromelt 72 MVA phosphorous furnace. 


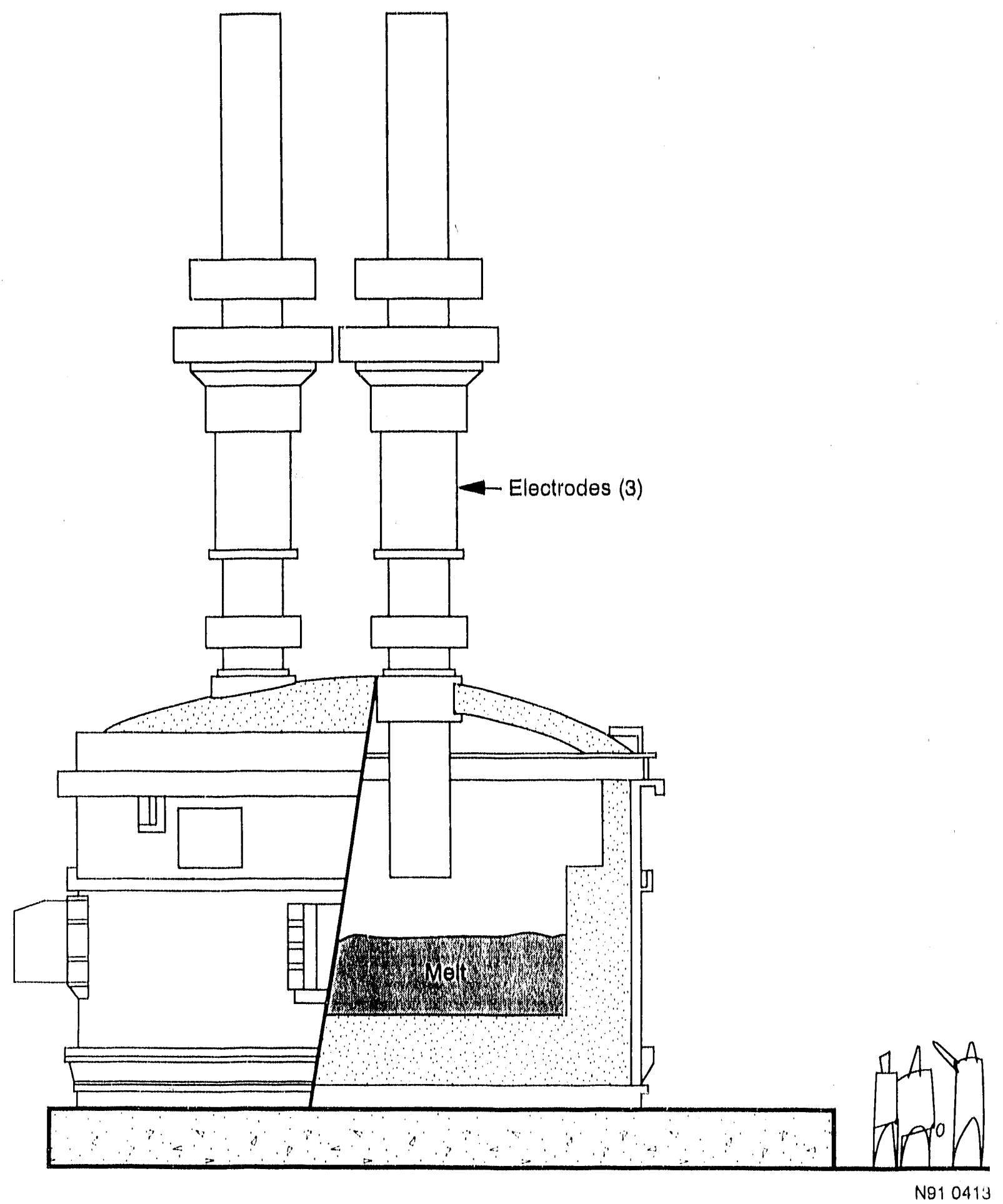

Figure 14. Lectromelt 16.5 MVA ferro-chromium furnace. 


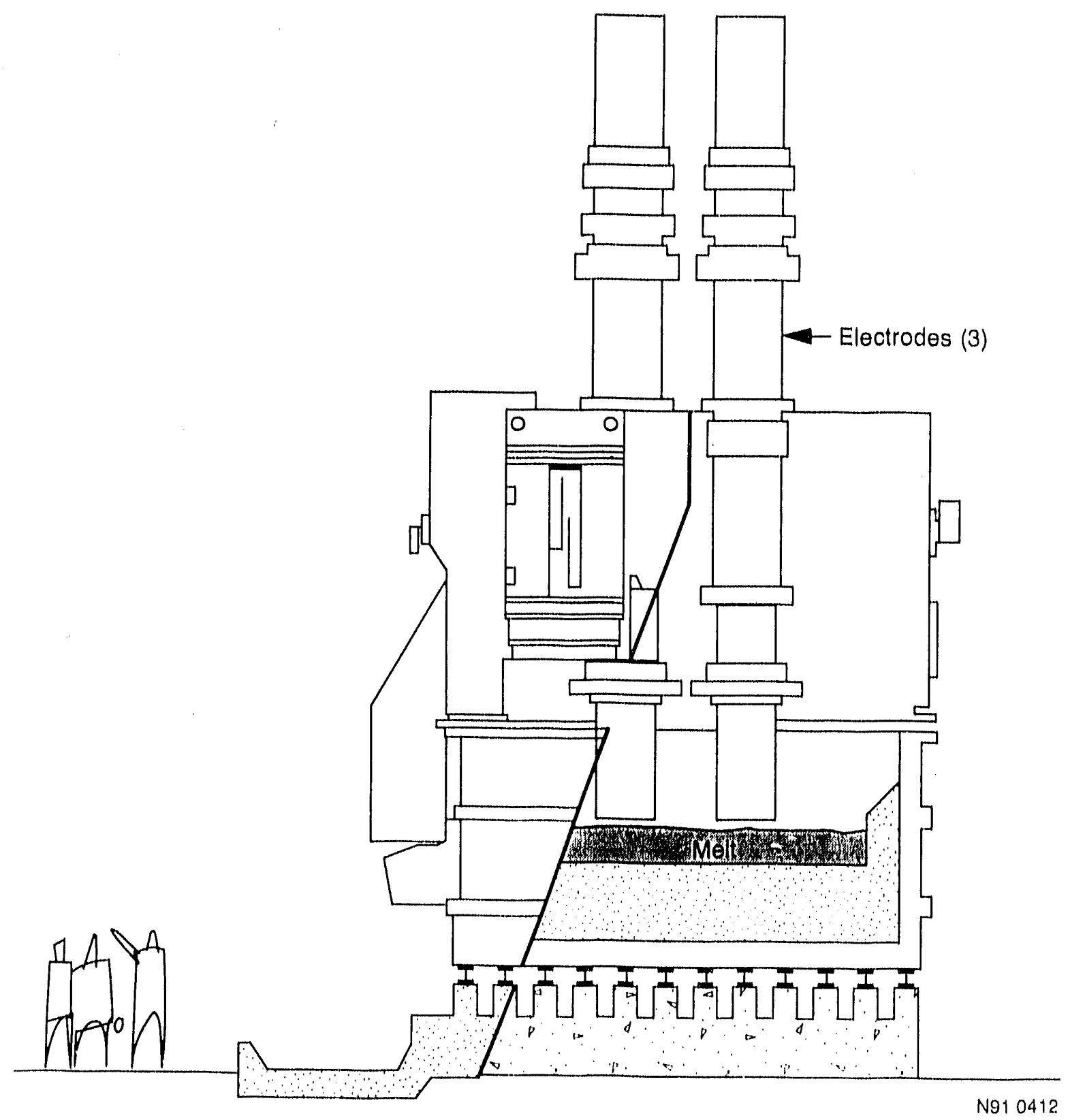

Figure 15. Lectromelt $6.5 \mathrm{MVA}$ metal recycling furnace. 


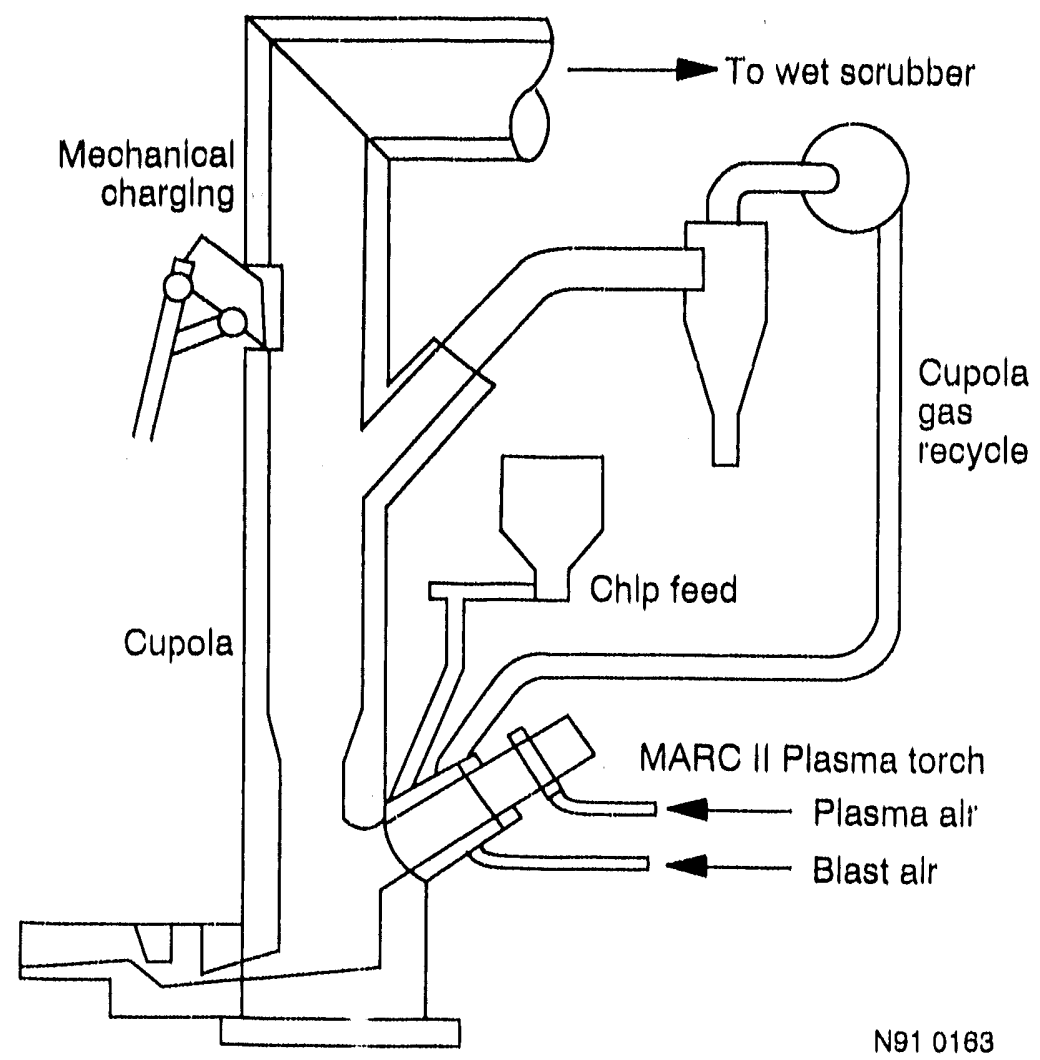

Figul'e 16. Westinghouse plasma-fired cupola. 
Scorpion Mfg ${ }^{19}$ has a carbon are device for pyrolysis of organic waste, such as municipal waste and tires. A commercial unit rated at 350 tons per day is being installed at a landfill in Milan, Italy. An example of the Scorpion pyrolyzing furnace is given in Figure 1.

Plasma Technology Inc. is trying to develop a plasma induction torch built by TAFA for waste processing applications. The TAFA induction torch is a high efficiency ( $\% \%$ clectrical to heat) device available in megawatt power levels. It is basically a gas heater that would accomplish much the same job as the Westinghouse are torch, possibly with more llexibility in choice of gases. They do not provide a complete furnace system.

Quantum Tech builds and operates an arc pyrolyzer that is presently developed for application to liquids and gases. They claim that it is adaptable to the processing of contaminated soils.

\subsubsection{University Arc/Plasma Technology Developers}

A number of universities have plasma research programs that are related to melters. The University of Missouri has a Bureau of Mines supported Generic Mineral Technology Center for Pyrometallurgy in the Dopartment of Metallurgical Engineering that does both theoretical thermodynamic studies as well as experimentation. The University of Minnesof a has a similar Mineral Resources Research Center, affiliated with the Department of Civil and Mineral Enginecring, which are the largest and most comprehensive mineral processing facilities integrated into a U.S. university. A number of other universities doing fundamental research on plasma arcs include The University of Minnesota (Mechanical Engineering) and the State University of New York at Buffalo (Computer and Electrical Engineering), which is aftiliated with the New York State Center for Hazardous Waste Management. This is by no means a comprehensive list. MIT is collaborating with EPI Inc. to test a small de are furnace and the University of Idaho has participated in plasma metallurgy work with the INEL. Georgia Tech and UCLA have been involved in plasma are and inductive torch development.

\subsection{Other Related Developments}

There are several melter and thermal oxidation processing technologies that have been assessed by SAIC in conjunction with EG\&G for potential ex situ processing of the INEL buried TRU mixed wastes. A summary of the SAIC assessments reported in References 5 and 18 are as follows.

\subsubsection{Microwave Melter}

Japan has applied direct $\mathrm{MW}$ heating to convert $\mathrm{Pu}$ nitrate sludge to $\mathrm{PuO}_{2}$ and to vitrify waste incinerator ash to inert solids. INEL vitrified HLW with additives in MW in the 1970's. Rocky Flats Plant used two MW systems in the late 1980)'s to dry and vitrify metal hydroxide sludge secondary waste stream from treatment of aqueous wastes containing toxic heavy metals. In the MW dryer, the temperature is only $1(0)-200^{\circ} \mathrm{C}$ and has a throughput of $6-12 \mathrm{~kg} / \mathrm{hr}$. 'The temperature of the $\mathrm{MW}$ 
melter is operated around $1300^{\circ} \mathrm{C}$ and has a throughput of $2-3 \mathrm{~kg} / \mathrm{hr}$. The advantages of this technology include: high heating efficiency for drying (65-97\%), effective uniform heating method for solids, very low offgas for good containment, and in container melting minimizes handling. Disadvantages of the technology include: for drying - high cost, nonunilorm f'eed and large objects Impair operation, and need even distribution of materials on a flat surface; for melting - high cost, low process throughput $(25 \mathrm{~kg} / \mathrm{hr}$ ), small batch mode operation (one 55 -gallon drum), not applicable to combustibles, most suitable for aqueous based sludges only, and the eflect of large metal objects is not known.

\subsubsection{Ausmelt Lance}

Developed in Australia (1981) for high efficiency smelting of a wicle range of materials, this technology delivers process air and fuel beneath the surface of a slag bath. Very turbulent conditions are created, which homogenizes the bath in a relatively short time. This condition results in a high process capacity for a small furnace volume. The technology is capable of accepting a wide range of feed with minimal feed preparation. Advantages of the technology include a potentially simple, rugged, and versatile method for thermally treating heterogeneous wastes, proven for large-scale (5 tons/hr) smelting operation, apparently no size limitation, and low cost. The disadvantages of the technology include untested applications to temperature limitations of fuel fired heating (although this design is very efficient) for hazardous and radwastes, containment needs development, large offgas volume increases offgas and particulate handling costs, not appropriate for combustibles, and high-temperature operation increases volatilization of HVPM.

\subsubsection{Molten-Metal Bath}

The Molten-Metal Bath uses a pool of molten metal to transfer heat to waste materials to break down organics and to vitrify inorganic materials to a slag. Usually steel is the bath medium and other metals can be tailored to the process need. Applicable waste treatment data on this technology are extremely limited making assessment of the technology highly speculative. Advantages of the technology include high temperatures, long residence time, stable slag form, minimum $\mathrm{NO}_{x}$ generation, proven technology for scrap metal recovery, low offgas volume, high particulate retention in the bath and slag, stable and uniform temperature in a large bath, the reactor is simple, compact and air tight, and radiologically contaminated metals could be used for the bath. The disadvantages of the technology include high volatilization of HVPM and radionuclides because of high temperatures, inert wastes must be extensively sized for subsurface injection, not suitable for aqueous liquids or wet solids, slag chemistry may be difficult to optimize for heterogeneous wastes, and the technology has not been demonstrated and is unlikely suitable for large volume of soil applications. 


\section{CONCEPTUAL MELTER PROCESS DESIGNS}

In order to place the melters within a complete process system context, this section presents brief descriptions and flow charts of four potential processes. There is no attempt to specify how the functional component tasks are to be accomplished. This section simply shows the basic cells for an alpha material processing system. All cases require a feed system, a systen for handling the final products, and an offgas treatment system. Each separate system would be tailored for the particular concept and would not necessarily include the same equipment. Additional conceptual design consideration of potential thermal process systems for the INEL wastes is provided in Reference 3.

\subsection{Plasma Arc/Torch Furnace Concept}

Figure 17 depicts a conceptual process flow diagram for a plasma arc/torch furnace. It is assumed that no matter which process is selected the retrieved waste will come into the facility prepackaged in a container that is consumable. Because the facility will most likely be designated a radioactive solid waste handling facility and come under DOE 6430.1A regulations, entrance of items into the pretreatment area must be through airlock type pessages to prevent the spread of alpha contamination. In the pretreatment area, the unopened package and its contents are first appropriately sized for processing in the plasma furnace; this sizing operation mixes some of the waste to help the process. Sizing is done as the first pretreatment step rather than as the last step in a sequence of opening the waste package, sorting the contents, and then sizing only the waste stream going to the furnace. This is the only way a production type bulk processing operation can proceed. Hands-on sorting of individual packages is extremely time consuming and is not consistent with the intent of ALARA. Therefore, once the waste is sized, it is mechanically sorted to remove as much of the metals as possible. The removed metals are sent to a decon station for cleaning, if they can be deconned to an acceptable level they are packaged and removed from the facility for disposal as low-level waste (LLW). Those metals not meeting the established requirements for disposal and the residue from the decon operation are fed into the plasma furnace along with the other sized material.

In this scenario, the plasma furnace is desig red to handle the average flow of organics and combustibles contained in the waste without upsetting the process. When a large amount of organics are present, the furnace environment becomes reducing and the volatiles are driven off necessitating use of a secondary combustor. It is assumed that the high vapor pressure metals will stay in the furnace and be captured and oxidized in the slag. Because the retrieval of the waste is random (the selection of containers is as they occur in the pit or trench), the composition of the waste will vary and the process will see spikes making energy recovery impractical. For heat, the furnace incorporates a water cooled, transferred arc plasma torch that uses air or oxygen as the plasma gas. It is assumed that all the material will be oxidized and be part of the slag but a method of removing unoxidized metal will be provided in case complete oxidation does not occur. The slag is removed using conventional industry tapping techniques adapted for alpha confinement. A sample of the product is taken during the pour to determine if its properties will meet established acceptance criteria. If unacceptable, it can be cooled, packaged, and sent back through the process. A system 
for additives will be included to adjust the slag properties and assist in pouring; if acceptable, it is cooled in a controlled environment, packaged, and moved to a shipping area for proper disposal. Any free metal will be tapped off separately then cooled and packaged for disposal.

Volatile gases generated in the furnace are sent to a secondary combustor for destruction. The total offgas stream is then treated first by a wet scrubber that cools and neutralizes the gas and removes some of the particulate. Next, they enter a venturi scrubber where the majority of the particulate is removed and further cooling takes place. The entrained moisture added in the scrubbers is then removed in a demister, however, not all of the moisture can be removed and it is necessary to vaporize the remaining water droplets by use of a reheater located just upstream of the HEPA filter bank. This vaporization protects the HEPA filter from becoming saturated and blowing out under pressure. The ash from the secondary combustor and the particulate residue from the scrubbers and the demister is recycled back to the furnace. The whole process system from the feed inlet through the filter bank operates under a negative pressure created by an induced draft fan situated downstream of the filter bank and just prior to the stack. The exhaust gases are continuously monitored for hazardous and radioactive constituents as they are discharged out the stack.

\subsection{AC Transferred Arc Furnace Concept}

Figure 18 shows a concept for a process using an ac transferred arc furnace. Comparing Figures 17 through 20, it is seen that the transport of the waste package through airlocks and initial pretreatment (sizing and metals removal) of the waste is the same for all concepts. It is also assumed for this concept that the waste package containing the retrieved waste is consumable. In this concept no metals will be intentionally fed to the furnace, they will be removed from the shredded waste stream and sent to a decon station. That portion that can be cleaned to acceptable levels will be packaged and removed for disposal as low-level waste. That portion that does not meet the acceptance criteria will be packaged in a different area and removed for disposal probably as TRU waste. Only the residue from the decon operation will be part of the input stream. The remainder of the waste stream is fed to a roaster unit to drive off the organics, which if not removed, could cause problems in the furnace. Too high an organics loading could drive the furnace environment into a reducing condition causing the high vapor pressure metals to evaporate. However, small amounts can be tolerated without adverse consequences. The vaporized organics are sent to a combustor for destruction. The offgas from the roaster will be treated in the same train as the main offgas stream. Ash from the organic combustor and the remainder of the waste stream plus the residue from the metals decon station is fed to the furnace in a continuous mode.

The furnace bath is heated by three 3-phase moly electrodes that are automatically adjusted to maintain the arc at its optimum. The bath is only slightly oxidizing, which means the metals will probably exist in the reduced state and have to be removed separately from the slag. As in the previous concept, the slag and metal will be removed using conventional tapping techniques adapted 


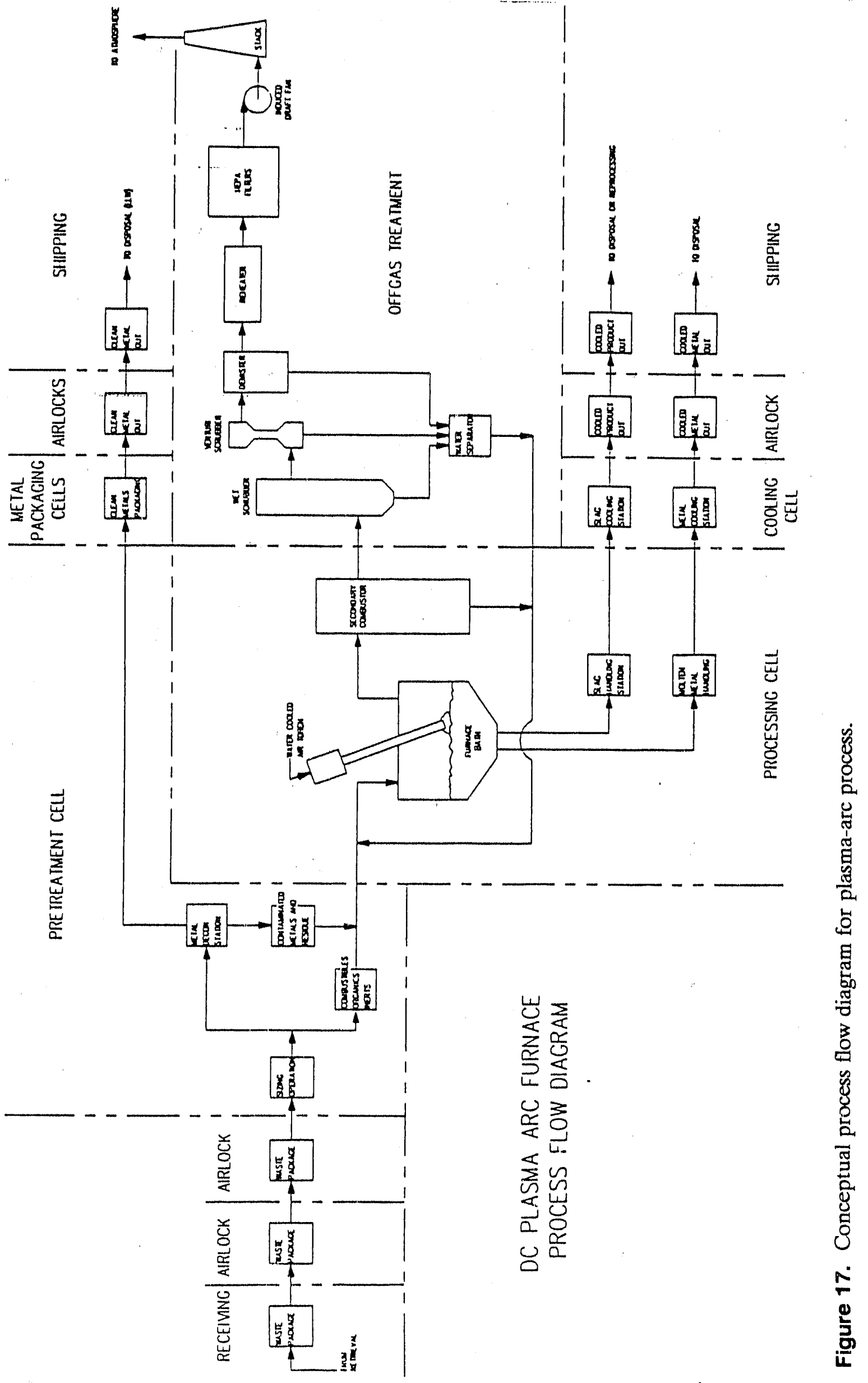




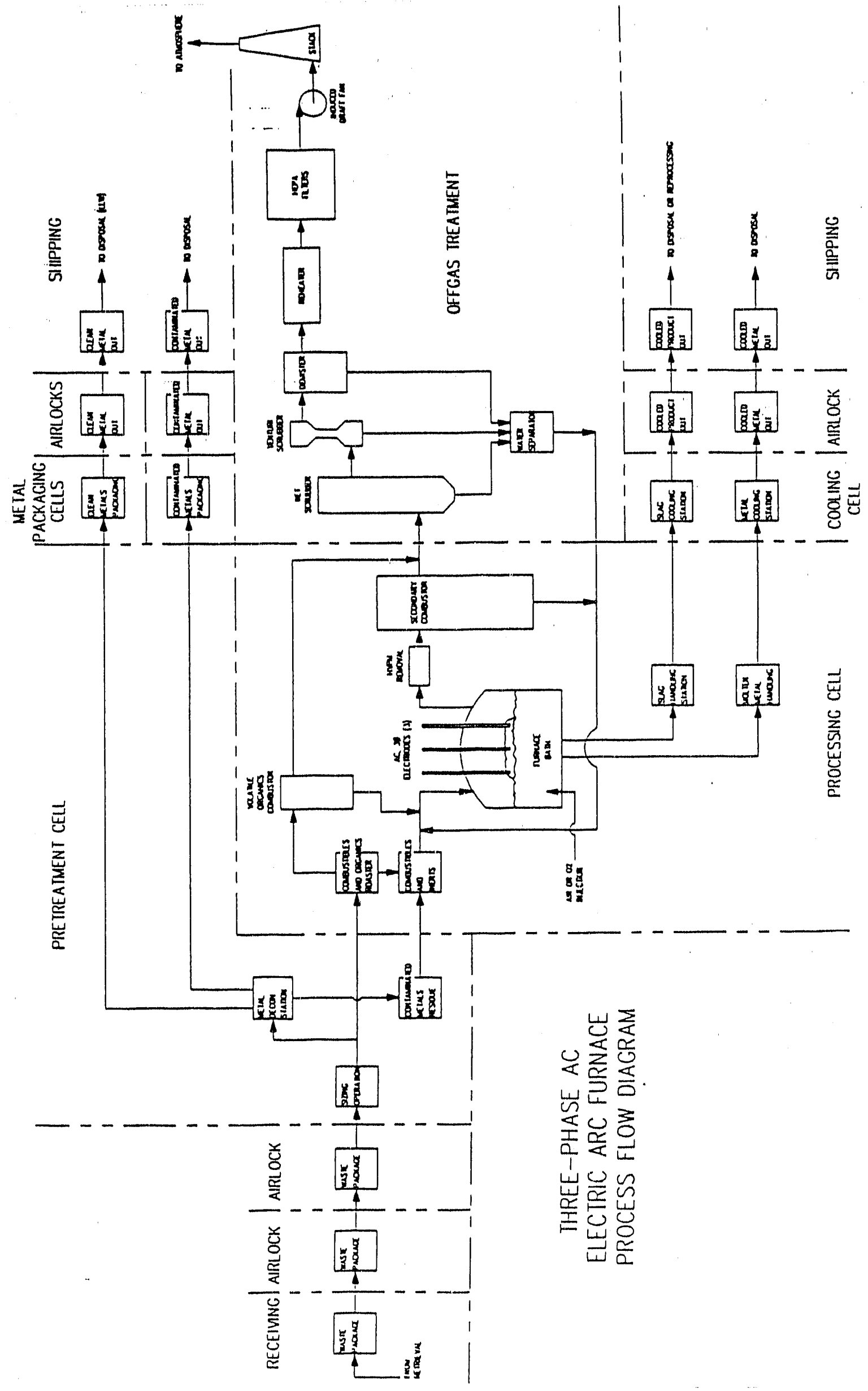

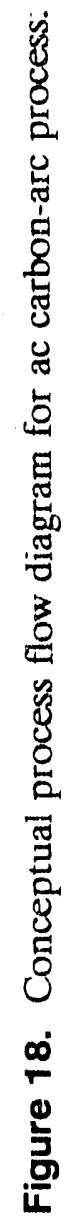




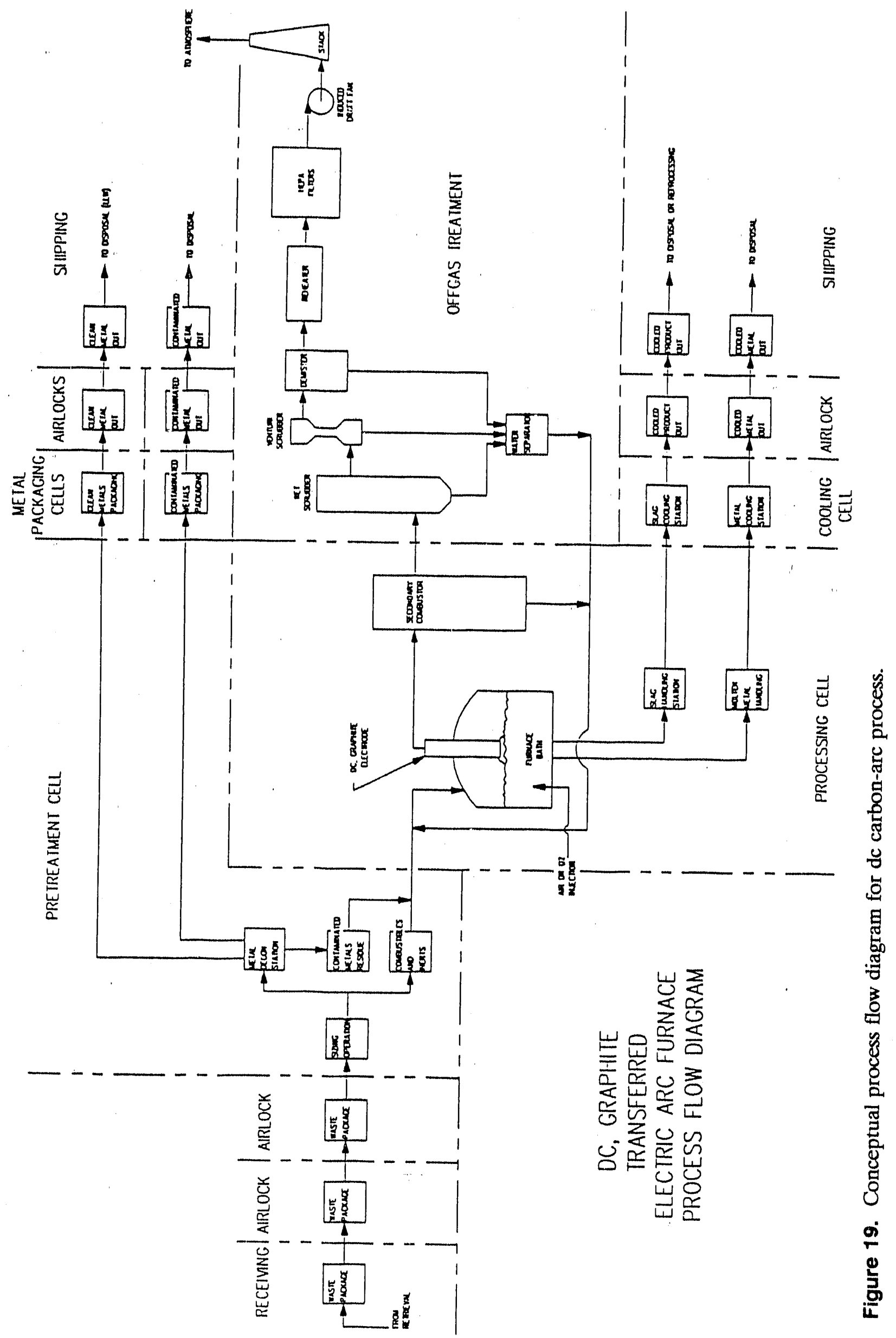




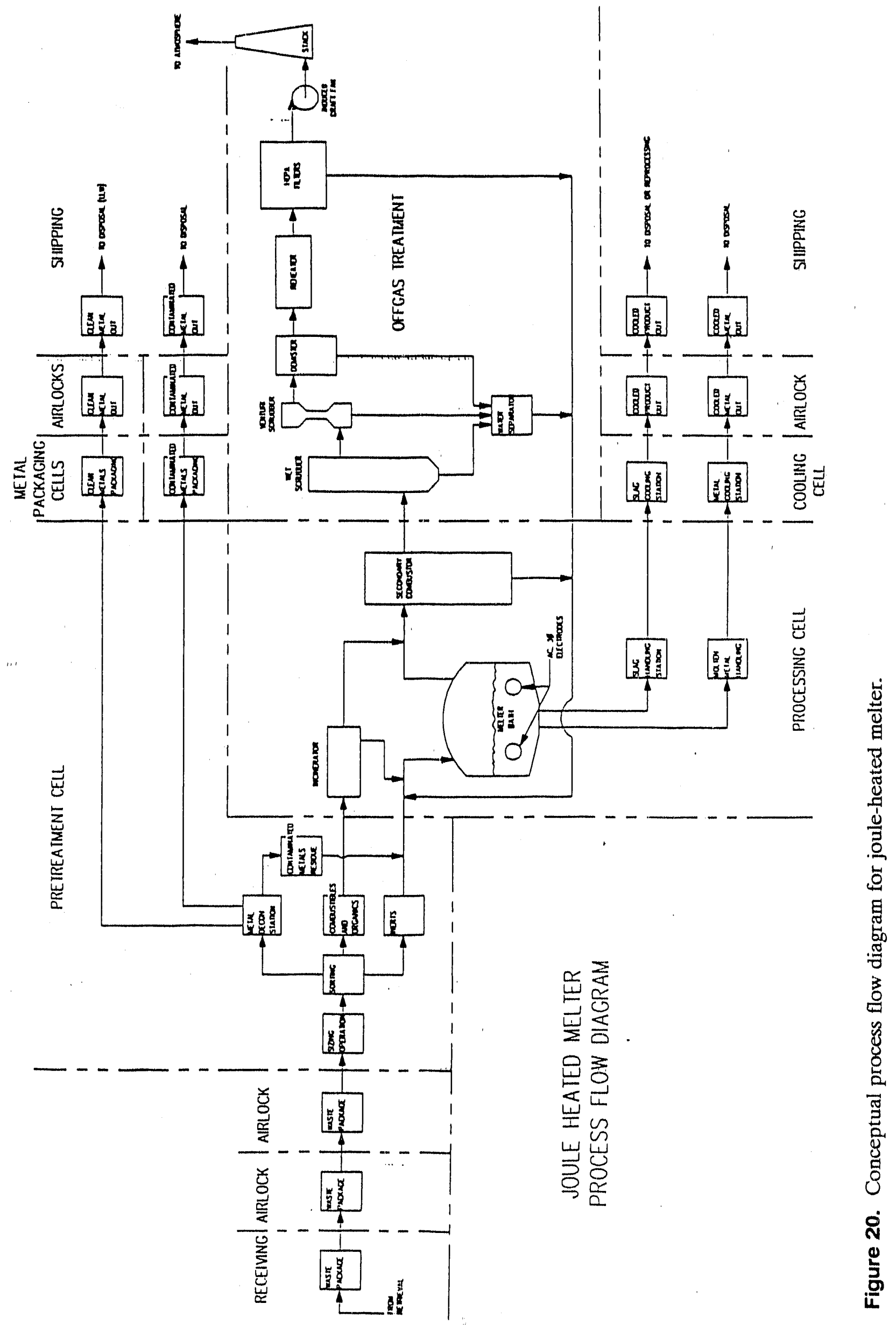


for alpha confinement. Also, a sample of the product is taken during the pour to determine if its properties will meet established aceeptance criteria. If it is not acceptable, it can be cooled, packaged and sent back through the process. A system for additives will be inclucied to adjust the slag properties and assist in pouring. If aceeptable, it is cooled in a controlled environment, packaged, and moved to a shipping area for proper disposal. The free metal will be tapped off, separately cooled, and packaged for disposal.

The gases generated in the furnace will probably contain high vapor pressure metals (HVPM) that will be released and need to be captured. A system immediately downstream of the furnace will remove those HVPM by condensing them and trapping in a filter medium. A secondary combustor destroys the volatile constituents prior to the offgas treatment system. The offgas stream is treated first by a wet scrubber whose main finction is to cool and neutralize the gas but also to remove some of the particulate. Next, they enter a venturi scrubber where the majority of the particulate is removed and further cooling takes place. The entrained moisture added in the scrubbers is then removed in a demister, however, not all of the moisture can be removed and it is necessary to vaporize the remaining water droplets by use of a reheater located just upstream of the HEPA filter bank. This vaporization protects the HEPA filter from becoming saturated and blowing out under pressure. The ash from the secondary combustor and the dried particulate residue from the scrubbers and the demister is recycled back to the furnace. The whole process system from the roaster through the filter bank operates under a negative pressure created by an induced draft fan situated downstream of the filter bank and just prior to the stack. The exhaust gases are continuously monitored for hazardous and radioactive constituents as they are discharged out the stack.

\subsection{Transferred Arc Furnace Concept}

Figure 19 shows a concept for a process using a de transferred are furnace as the main processing unit. Like the previous concepts presented, the transport of the waste package through airlocks and initial pretreatment of the waste is the same. The same type of waste package and the fact that it is consumable holds true for this concept; like the ac transferred arc furnace, no metals will be intentionally fed to the de arc furnace. They will be removed from the sized waste stream and sent to a decon station. The portion of the metals that can be cleaned to acceptable levels will be packaged and removed for disposal as low-level waste. That portion that does not meet the acceptance criteria will be packaged in a different area and removed for disposal probably as TRU waste. The residue from the decon operation will be part of the input stream to the furnace. The remainder of the waste stream is continuously fed to the furnace where the destruction process is pyrolytic; resulting in reduced offgas generation and $\mathrm{NO}_{x}$ production.

The heat source for this process is a single, large, hollow, graphite de powered electrode, which tends to maximize the stability and robustness of the process. It is assumed that volatilization of high vapor pressure metals will not be a problem because the noncombustion pryrolytic process does not produce high gas volume:, which would cause vapor and particulate material to be carried out of the system. It is anticipated that volatilized material will condense on the particles above the molten bath 
and not leave the furnace. The volatile gases created will be destroyed in a secondary combustor designed to minimize the generation of additional offgas without encrgy recovery considerations. The same offgas treatment components, as shown for the plasma arc and ac transferred arc lurnace processes, are proposed for the de arc furnace concept except they will be designed specifically for the anticipated gas species from this process. Likewise, the slag and metal handling systems will probably be the same as the two previous concepts. Small amounts of free metals are expected and need to be handled separately from the slag.

\subsection{Joule-Heated Melter Concept}

Figure 20 shows a concept using a joule-heated melter in conjunction with an incincrator to process the waste. The front part of the process is the same; that is, transport into the pretreatment cell via combustible containers and the initial sizing of the waste. For this process, the sized waste is sorted into a metals stream, an inerts stream, and a combustibles and organics stream. As in the transferred arc furnaces, no metals will be intentionally fed to the joule-heated melter. Again, the metals are treated and disposed based on meeting the established acceptance criteria. The decon residue along with the inerts stream and the ash from the incineration of the combustibles and organics are fed in a continuous mode to the melter. Because the melter temperature is limited compared to the plasma arc furnaces, the melting of iron enriched soils and any trace metals may need to be assisted by the addition of fluxes. It is anticipated that the unit will be operated with a cold cap thereby eliminating the evaporation of high vapor pressure metals and the need for any HVPM removal equipment. The process energy is generated by passing an alternating current between submerged electrodes through the molten bath. The electrical resistivity of the glass causes joule heating; which maintains the bath at the desired operating temperature allowing reactions to occur. Without adding oxygen to the bath it is guaranteed that metal will accumulate in the bottom of the melter necessitating removal to prevent a shorting path through the electrodes. Conventional metal tapping techniques will be adapted for operation in an alpha contaminated environment; slag handling will be the same as for the other concepts presented; tapping the melter will be based on conventional industrial techniques; and product sampling and handling requirements do not change based on the process used to generate the final product.

The combustibles and organics are processed in a specifically designed incinerator. Offgases generated are routed through a secondary combustor to guarantec complete combustion of all volatiles and hazardous constituents. The gases from the melter are also routed through the secondary combustor prior to entering the offigas treatment system. The offgas from the secondary system is treated using the same components as the other concepts presented. Each concept will have the components tailored for the specific application. 


\section{CRITICAL ISSUES AND DEVELOPMENT NEEDED}

\subsection{Overview}

This section summarizes critical questions/issues identified in the assessment of melter technology relative to the treatment process and identilies the need for particular technology developments. The companion study on INEL waste materials processing (Reference 3) discusses aspects of the wasto materials, and proeess chemistry to obtain the best waste form. The following six primary melterrelated problems or questions have come from assessing the available melter technology in light of the study:

1. Sizing considerations with respect to alpha containment.

2. High vapor pressure melal volatilization.

3. TRU, LLW, and metal oxidation.

4. Corrosion/erosion or degradation of electrodes and/or refractories.

5. Process operating conditions, slag composition, and controlled cooling to obtain the optimum final waste form.

6. Reçuired offgas treatment to collect HVPM and/or treat $\mathrm{NO}_{\mathrm{x}}, \mathrm{SO}_{\mathrm{x}}$, etc.

The relation of these critical topics will be discussed in regard to JHM, AHM, and PHM, as well as the numerous interrelated phenomena.

\subsection{Critical Issues}

\subsubsection{Sizing Considerations}

One important consideration is how well does the waste have to be characterized, sorted, and sized to be acceptable to the thermal treatment? The acceptable feed size for each unit is also a question because most vendors say 3 to 6 in. cubes are as large as they would want to put in their units. The only component of the SDA waste that approaches a powder feed is soil and waste ash, if the combustible waste portion is incinerated. Hands-on sizing is too time consuming and not consistent with ALARA. Shredding is a possibility but doing it in an alpha containment is not easy because the delivery and discharge systems have to be totally sealed and designed for remote maintenance. If the waste is segregated, the metals are removed and decontaminated, the combustibles and noncombustibles are removed and separated, (combustibles sent to an incinerator), and the soil is separated and washed. However, there is still a sizing problem inherent to segregation. 
Sealing a high-temperature unit for alpha containment is a dillicult task. Penctrations for the feed inlet, electrodes, Instrumentation, the slag tap, and the off-gas outlet present numerous sealing challenges. Once sealod, it is difficult to prevent contamination from spreading into the working space during a pressure spike especially with moving parts such as sliding doors (valves) and rotating shafts.

If the alternative with both a medium-T JHM and a high-T PHM is to be used, the sorting must be done, and with good definition for the JHM. If only PHM are used, the robustness of the system will allow a minimum of sorting, thus minimizing the alpha containment problem. A detailed study of the alpha containment is beyond the scope of this work.

\subsubsection{HVPM Volatilization}

The HVPMs to be concerned with are $\mathrm{Ag}, \mathrm{Ba}, \mathrm{Cd}, \mathrm{Cr}, \mathrm{Hg}, \mathrm{Pb}$, and $\mathrm{Zn}$, and $\mathrm{to}$ a lesser degree, Cs-137. The metals have much lower boiling points than the oxides. Some of the values of melting and boiling points, densities, and electrochemical potentials (ECP) are given in Table 2. Various HVPMs will evaporate from the slag at the higher melting temperatures of $15(0) \cdot 16(1) 0^{\circ} \mathrm{C}$. It appears that there may be strategies for containing these elements in the molten slag if they can be oxidized, for instance, cesium was found to have less volatility than expected. ${ }^{20,21}$ Other pertinent questions include: How does the redox condition of the melt and/or the atmosphere above the melt affect the transport? Will a cold cap be applicable?

Plutonium oxy-hydroxides may exhibit high vapor pressure at relatively low temperatures. The formation of these compounds might be aggravated by the presence of water vapor, as in an oxidizing environment with organics present.

Provided they are not plugged, cold caps (or burden) above the melt will filter the oll'gas leaving the melt. Pyrolysis of organics will occur in the cold cap and HVPMs will condense out in the cold cap. As the cold cap melts, HVPMs will be returned to the melt and the vapor pressure of the HVPMs locally above the melt but within/below the cold cap will lend 10 increase; which will help to contain these elements in the melt. In the extractive metallurgy industry, the size of the cold cap constituents and their chemistry and physical condition are carefully controlled to maintain porosity, however, this control is much more difficult or impossible in waste treatment. Westinghouse has experienced problems with plugging of their cupola in treating of PCB-contaminated soil. The glass melter vendors seem to have had better success with cold caps because the electrodes are within the melt and provide regions for vapor release. In PHM, the cold cap could be used in a reducing, pyrolyzing atmosphere, but in an oxidizing environment may result in rapid oxidation of graphite electrodes in arc melters.

Melt temperature, lluxing, HVPM, redox state, and final product performance characteristics (leaching) are interrelated. The vapor pressure and the losses of HVPM's increase with increasing 
Table 2. Propertics of HVPM.

\begin{tabular}{|c|c|c|c|c|c|c|c|}
\hline \multirow[b]{2}{*}{ Element } & \multicolumn{2}{|c|}{ Mclting points $\left({ }^{\circ} \mathrm{C}\right)$} & \multicolumn{2}{|c|}{ Boiling Points $\left({ }^{\circ} \mathrm{C}\right)$} & \multicolumn{2}{|c|}{ Densities (SG) } & \multirow[b]{2}{*}{$\mathrm{ECP}$} \\
\hline & Motal & Oxide & Metal & Oxide & Metal & Oxide & \\
\hline $\mathrm{Fe}$ & 1538 & $\begin{array}{l}1420(a) \\
1.565(b) \\
1538(c)\end{array}$ & $30(x)$ & $\begin{array}{l}-\cdot \\
\cdots \\
--\end{array}$ & 7.87 & $\begin{array}{l}5.7 \\
5.24 \\
5.18\end{array}$ & $\begin{array}{r}-0.409 \\
-0.036\end{array}$ \\
\hline $\mathrm{Ag}$ & 961.9 & $\mathrm{~d} 3(\mathrm{O})$ & 2214 & -. & 10.49 & 7.143 & +07996 \\
\hline $\mathrm{Ba}$ & 714 & 1923 & 1643 & $\cos 20(0)$ & 3.5 & 5.72 & -2.90 \\
\hline $\mathrm{Cd}$ & 321.1 & $\begin{array}{l}<1426 \\
d(9)()\end{array}$ & 765 & $\begin{array}{l}\mathrm{d} 9(0)-1000) \\
\text { subi } 1559\end{array}$ & 8.65 & $\begin{array}{l}6.95(\mathrm{am}) \\
8.15 \text { (cub) }\end{array}$ & -4.026 \\
\hline $\mathrm{Cr}$ & 1878 & 24.35 & 2620 & $40(0)$ & 7.19 & $\begin{array}{l}5.12 \mathrm{Cr} 203 \\
\mathrm{CrO}\end{array}$ & $\begin{array}{l}-0.74 \\
-0.557\end{array}$ \\
\hline $\mathrm{Hg}$ & -.38 .4 & $d 1(x)$ & 3.57 & -. & 13.55 & 9.8 & +0.851 \\
\hline $\mathrm{Pb}$ & 327.5 & $888(\mathrm{PbO})$ & 1728 & -. & 11.36 & 9.53 & -0.1263 \\
\hline $\mathrm{Zn}$ & 419.6 & $1975(\mathrm{ZnO})$ & 907 & -. & 7.13 & 5.606 & -0.7628 \\
\hline
\end{tabular}

Key:

$\begin{array}{ll}a & \mathrm{FeO} \\ \text { b } & \mathrm{Fe}_{2} \mathrm{O}_{3} \\ \mathrm{c} & \mathrm{Fe}_{3} \mathrm{O}_{4} \\ \text { am } & \text { amorphous } \\ \text { ca } & \text { approximately } \\ \text { cub } & \text { cubic } \\ \text { d } & \text { decomposes } \\ \text { subl } & \text { sublimes } \\ \text { ign } & \text { ignites }\end{array}$


temperature. Reducing the melting temperature should retain more HVPM's in the slag. A reducing melt will reduce H $\vee$ PM's 10 the metallic state with higher vapor pressure, increasing the evaporation rate. A high organic loading in the feed stream will tend to make the melt reducing unless the organic input is balanced by sufficient air or oxygen. The addition of lluxes such as alkali metals, calcium, and/or boron will reduce the melting temperature, perhaps allowing the retention of HVPM's. However, addition of fluxes will reduce the leach resistance and physical durability of the waste form and increase final waste form volume.

A more detailed, experimental study is necessary to determine the optimum melter conditions to limit volatilization of HVPM in the systems process setting.

\subsubsection{TRU, LLW, and Metal Oxidation}

Surface contamination of metals by TRU should be removed by oxidation and solution into the melted slag. The TRU and uranium (and most other metals) will be preferentially oxidized by the iron oxide in the slag. The iron must then be reoxidized by air, oxygen, or some other oxidant, or be contained in the waste form as metallic iron. The reduced metal collected beneath the slag layer might very well be in a decontaminated state with all the TRU contaminant partitioned into the slag as an oxide.

It should be possible to decontaminate the metallic surfaces by oxidation in the melt or slag, allowing the decontaminated bulk of the metal to sink to the bottom for dredging. The process can be controlled by limiting the oxygen supplied and by agitating or bubbling the air or oxygen into the melt. ${ }^{22}$ It is unproven whether all the metal can be oxidized in this manner, but the referenced experiment indicates reasonable residence times.

The JHM is inappropriate for oxidation of metals in the melt at the medium and hightemperature range because the electrodes would be oxidized as well. The graphite-electrode employed in the are melter could be similarly oxidized in the atmosphere above the melt, but have been found to resist oxidation if properly coated with $\mathrm{SiC}$ or equivalent as a surface protectant. In the latter case, surface oxidation with limited oxidant should be achievable. The transferred-are plasma torch is reported to work readily in an oxidizing melt and atmosphere without oxidation problems. ${ }^{d}$

An experimental study is necessary to determine the appropriate methods and oxidation rates for both surface and total oxidation of metals. The efficiency of the slag to oxidize and to remove TRU/LLW and/or a uniform coating from the contaminated metal should be measured.

d. Personal communication with Steve Kujawa, INEL/MSE CDIF, September 1991. 


\subsubsection{Corrosion and Erosion of Electrodes and Refractorles}

Although low temperature joule melters using Inconel 690 electrodes will not have significant electrode corrosion problems, medium-lemperature melters using molybdenum or carbon electrodes might suffer rapid electrode corrosion if in an oxidizing environment. High-temperature JHM electrodes will corrode rapidly even in a reducing environment. Because this will be an alpha operation, remote maintenance and operation is a given. Long electrode life is a must in this situation or at least extreme ease in changeout of electrodes must be available. The electrodes must. be selected for the high temperatures required and the changing nature of the waste composition. Corrosion effects on the electrode will increase if the glass bath is vigorously stirred to promote mixing or oxygen is bubbled through to enhance oxidation of the metals.

In order for joule-heated melters to reach the temperatures necessary to melt many metals and basalt it will be necessary to use carbon or molybdenum electrodes. These electrodes are susceptible to oxidation in the melt or above it. PNL, has designed a melter for municipal ash that will use Mo or $\mathrm{C}$ topdown electrodes for intended operation at temperatures of $s 150()^{\circ} \mathrm{C}$. Mo electrodes are also subject to oxidation by ferric iron in the melt. Moderate cost bench-scale experiments in crucibles could be used to resolve the limits of this problem.

Graphite-electrodes for arc melters are consumable; this reduces the maintenance problem. The electrodes must be coated to minimize oxidation in the atmosphere above the melt, but limited oxidation in the melt is acceptable. In oxidizing environments, the carbon will oxidize to $\mathrm{CO}$ and $\mathrm{CO}_{2}$ and leave in the offgas. In reducing environments, metal carbides will form in small concentrations in the melt, thus altering the final waste form microstructure and possibly the leach rate. Material characterization of typical waste forms with the metal carbides should be made, as well as meaningful leach tests.

Transferred and nontransferred-plasma arc torches with water-cooled metal electrodes can operate for hundreds of hours in adverse environments if: 1) the metal alloys are properly selected or composed to minimize arc corrosion and erosion and 2) the current density at the torch electrodes is sufficiently low. The electrodes (and torches if necessary) can be easily replaced and potentially dropped into the melt for processing as a waste. Custom torch designers with years of experience are presently availabie, to be focused upon this issue.

Corrosion and erosion of refractories in high-temperature vessels is a real problem in an alpha environment because repair or replacement must be done remotely. Manual repair is possible but the loss of operating time and personnel exposure make this method impractical. The biggest question regarding this problem is what refractory should be used in ihis atmosphere that will sustain adequate operating life? Also, the tenure of adequate life must be determined. Various refractories have been tested in high-temperature JHM experiments, proving the Ruby (predominantly alumina) refractory to be the best. ${ }^{23}$ Nevertheless, the refractory did wear and radioactive species migrated into it. An alternative is to use a water-conled skull or frozen slag layer next to a thimer layer of 
refractory. Tests indicate that buildup of radioactive species (due to migration l'rom the melt) is then not a problem. The glass/gas interface in both the JHM and PHM is a region of crosion/corrosion and must be protected, especially in an oxygen-enriched environment.

During bench tests on the reactions of high vapor pressure metals and transuranic elements it was discovered that newer refractories should be investigated, as well as the use of' a skull. 'This foresight will give a designer a head start when making material selections for a pilot-sciale unit.

\subsubsection{Conditions Affecting the Finui Waste Form}

The IEB waste form has relatively broad compositional ranges for the various metal oxides to be dissolved. The extent of contaminated soll available to provide the solvent base exceeds that needed by a factor of two to ten. Therefore, the composition is vital to any proposed Joule-heater system in which the composition affects the viscosity and the electrical conductivity in a critical manner for proper operation. The arc/plasma-heated systems are much less dependent on composition.

The operating conditions of the JHM are much more dependent on the composition than those of the PHM. Considerable amounts of fluxing agents will have to be added to the JHM melt to obtain reasonable viscosity and electrical conductivity with the INEL basaltic and metal-rich waste stream. The fluxes are alkali (sodium and potassium) compounds that lower the melt viscosity at a given temperature but decrease the integrity of the linal waste form produced as the amount of the added flux increases. The INEL soil has about $5 \%$ alkali oxides naturally and it would be undesirable from a final waste form performance and volume reduction standpoint to add more flux. With PHM operation, additional flux should not be needed.

The waste form can be either vitrified or crystalline. If the slag is cast as monolithic pieces, the interior will probably be crystalline (slower cooling allows crystal formation) while the surface will be vitrified. Maintaining a vitrified structure may require casting into water, which will shatter the slag into frit. Controlled cooling of the slag must be provided to give reproducible properties and to generate a fine crystalline microstructure. The recrystallization temperature, also a function of the composition and redox state, is important in determining the proper cooling cycle. Prior leach test results are difficult to compare because of different EPA tests, different leach conditions, and needs. The EPA TCLP test for toxic substances does not give meaningful results for radioactive species. As a result, available data appear to indicate that the erystalline form is preferred but more data are needed for TRU's and toxic metals to verify whether the crystalline (rock-like) or the vitrified (glasslike) phase is preferred and for which hazardous substance. In any event the melter system needs to be able to provide the desired controlled cooling phase once defined.

It is recommended that the previous IEB studies of controlled cooling and materials retention be examined and extended to determine the glass transition temperature, a betler indication of the range 
of recrystallization temperatures, identify resulting microstructure, and conduct standardized leachability tests for a variety of contaminants in order to optimize the final waste form.

\subsubsection{Required Offgas Treatment}

Detailed studies of the offgas treatment to collect HVPM and particulates, minimize $\mathrm{NO}_{\mathrm{x}}$ and $\mathrm{SO}_{x}$, and to ensure complete combustion are beyond the scope of this work. These are discussed in more detail in a companion report. ${ }^{12}$

One aspect of the offgas system affecting the melter operation and control is the vapor release rate. Variations in the rate of addition of organics and water to the process reactor will cause variations in the rate of formation of vapor. Downstream gas treatment devices are not usually capable of operating properly under conditions of large flow variation ( $>2: 1)$. Cold caps or burdens might mitigate this problem by acting as a buffer. It also might be better to separate the functions into separate unit operations. Instead of attempting to use the primary thermal treatment device (where melting takes place) both as dryer and oxidizer/pyrolyzer, it might be better to drive off both water and volatile organics in a low temperature $\left(300-400^{\circ} \mathrm{C}\right)$ roaster/kiln or an incinerator. The dry organic free (relatively) product could then be fed into the melting unit.

\subsection{Summary of Developments Needed}

Needed developments include the following:

1. A more detailed systems design to integrate the findings of the Thermal Processing Technologies Task and obtain a more explicit design on which to base specific R\&D activities.

2. A bench-scale experimental study to determine the conditions to limit volatilization of HVPM in the systems design setting.

3. A bench-scale experimental study to determine the appropriate methods and oxidation rates for both surface and total oxidation of metals, including the efficiency to remove TRU/LLW and/or a uniform coating from the metal.

4. New refractories and the use of a skull should be investigated during bench-scale experiments above.

5. Controlled cooling should be examined and extended to determine the glass transition temperature, a better indication of the range of recrystallization temperatures, resulting microstructure, and standardized leachability tests in order to optimize the final waste form.

6. Appropriate melter tests should be undertaken to determine the extent of perceived problem areas: HVPM, surface and metal oxidation, graphite electrode operation, electrode refractory corrosion, and possibly controlled cooling. 


\subsection{Facilities Avallable for Experiments}

Experimental facilities are limited in number and capability. There are only three existing arc/plasma facilities large enough to be considered pilot scale: one is the Retech PCR at The CDIF in Butte MT, the second is the plasma melter at Retech that has been set up to melt simulated RFP compacted drums, and the third is the Bureau of Mines/ASME municipal ash vitrifier in Albany OR. The Butte PCR does not, however, have sufficient power to melt at a rate commensurate with its physical size. PNL and Penberthy have the only joule-heated melters large enough to be considered pilot size. Lectromelt has a bench-scale, single phase, ac arc melter. There are no other arc/plasma bench scale facilities available, although, EPI is planning to set one up with MIT. PNL can measure physical properties of glass compositions in crucible tests. The INEL plasma laboratory has constructed a bench scale arc/plasma melter for small scale tests. The selection of experiments and facilities is an iterative process. There is not yet sufficient funding to develop facilities for performing a preselected list of experiments to answer all the questions. An experimental program must be developed to answer the critical issues with the facilities that are available. Therefore the present and future capabilities of the vendor facilities must be determined including the costs of performing experiments and iterated with the development needs. The various vendor organizations have developed a certain knowledge base through their past research efforts. The combined knowledge base is a resource that must be further understood and integrated into the present development effort. 


\section{CONCLUSIONS AND RECOMMENDATIONS}

\subsection{Systems}

Comparison of the heterogeneous SDA wastes with the capabilities of existing thermal vitrification waste treatment (melter) technologies indicates that by proper selection of treatment technology combined with separation and preparation of SDA wastes, a complete process for treatment of SDA wastes can be developed. No one thermal process technology is likely suitable for all of the waste types (e.g., roasters, incinerators, afterburners likely required with the melter); however, a combination of thermal technologies applied to suitably separated and prepared wastes will convert the wastes to safe forms suitable for long-term disposal.

An optimum system process will do the following:

- Stabilize the TRU in a rocklike waste form with the required leach resistance

- Separate or encapsulate the LLW in a form suitable for LDA

- Oxidize organic constituents to $\mathrm{CO}_{2}$ and $\mathrm{H}_{2} \mathrm{O}$

- Encapsulate HVPM's into a leach resistant matrix.

Existing JHM and A/PHM thermal treatment technologies have been shown to be capable of carrying out the above on narrowly defined waste streams. A/PHM have more robust capabilities for handling "as required" wastes and compositional variations. Two major areas of melter technological uncertainty exist: (a) Incorporation and retention of TRU in a slag phase during melting in the cooled product waste form under various temperature, redox, and bath composition process conditions, and (b) retention or control of HVPMs under the required melting conditions.

\subsection{Experimental Recommendations}

Table 3 contains a list of potential melter sources for tests and development work. Two critical issues that need immediate attention are TRU and HVPM retention in the slag phase, because the fundamental design of the melters is contingent upon whether or not TRU and HVPM can be retained in the slag.

1. TRU retention in slag: Several lanthanides can act as surrogates for TRU. These surrogates can be placed in a waste matrix and melted under various redox conditions at vendors. Retech and 
Table 3. Listing of vendors and test capabilities.

\begin{tabular}{|c|c|c|c|c|}
\hline Vendor & Technology & $\begin{array}{c}\text { Test } \\
\text { Capability } \\
\text { Description }\end{array}$ & $\begin{array}{c}\text { Maximum Power } \\
\text { and } \\
\text { Temperature }\end{array}$ & $\begin{array}{c}\text { Date } \\
\text { Available }\end{array}$ \\
\hline $\begin{array}{l}\text { Bureau of } \\
\text { Mines }\end{array}$ & $\begin{array}{l}\text { AHM, three } \\
\text { phase graphite } \\
\text { electrodes }\end{array}$ & $\begin{array}{l}\text { Melter with } \\
\text { launder and } \\
\text { metal tap }\end{array}$ & $\begin{array}{l}1.5 \mathrm{MW} \\
>1800^{\circ} \mathrm{C}\end{array}$ & January 1992 \\
\hline CDIF & $\begin{array}{l}\text { PHM, dc copper } \\
\text { torch }\end{array}$ & $\begin{array}{l}\text { Rotating hearth } \\
\text { (PCR) }\end{array}$ & $\begin{array}{l}600 \mathrm{~kW} \text { to } 1 \\
\mathrm{MW},>1800^{\circ} \mathrm{C}\end{array}$ & Available \\
\hline $\begin{array}{l}\text { Browning } \\
\text { Engineering }\end{array}$ & Plasma Torch & NA & NA & NA \\
\hline $\begin{array}{l}\text { Electro- } \\
\text { Pyrolysis/MIT }\end{array}$ & $\begin{array}{l}\text { PHM, dc single } \\
\text { graphite } \\
\text { electrode }\end{array}$ & $\begin{array}{l}\text { Melting pot, dc } \\
\text { graphite } \\
\text { electrode } 2^{\prime \prime} \\
\text { diam. }\end{array}$ & $\begin{array}{l}800 \mathrm{~kW} \\
>1800^{\circ} \mathrm{C}\end{array}$ & January 1,1992 \\
\hline Glasstech & $\begin{array}{l}\text { JHM, stirred } \\
\text { inconel melter }\end{array}$ & $\begin{array}{l}\text { Stirred inconel } \\
\text { melter }\end{array}$ & $\begin{array}{l}75 \mathrm{~kW} \\
1150^{\circ} \mathrm{C}\end{array}$ & $\begin{array}{l}\text { Mid-February } \\
1992\end{array}$ \\
\hline Lectromelt & AHM, dc or ac & $\begin{array}{l}\text { Single phase } \\
\text { Two electrode }\end{array}$ & $75 \mathrm{~kW},>1800^{\circ} \mathrm{C}$ & Available \\
\hline $\begin{array}{l}\text { Pacific } \\
\text { Northwest Lab }\end{array}$ & $\begin{array}{l}\text { JHM, inconel, } \\
\text { molybdenum } \\
\text { and graphite } \\
\text { electrodes }\end{array}$ & $\begin{array}{l}\text { Two inconel } \\
\text { units } \\
\text { One Mo } \\
\text { electrode unit }\end{array}$ & $\begin{array}{l}8 \text { and } 11 \mathrm{lt}^{2}, \\
12000^{\circ} \mathrm{C} \\
18 \mathrm{ft}^{2}, 500 \mathrm{~kW}, \\
1550^{\circ} \mathrm{C}\end{array}$ & $\begin{array}{l}\text { Available } \\
\text { August } 1992\end{array}$ \\
\hline $\begin{array}{l}\text { Penberthy } \\
\text { Electromelt }\end{array}$ & $\begin{array}{l}\text { JHM, Mo } \\
\text { electrodes }\end{array}$ & Melter, 4 tpd & $1400^{\circ} \mathrm{C}$ & Available \\
\hline $\begin{array}{l}\text { Plasma Energy } \\
\text { Corp. }\end{array}$ & PHM, all types & $\begin{array}{l}\text { Not presently } \\
\text { available }\end{array}$ & NA & NA \\
\hline Retech & PHM, all types & $\begin{array}{l}\text { (1) PCR } \\
\text { (2) Hearth }\end{array}$ & $\begin{array}{l}\text { Both: } 100 \mathrm{~kW}, \\
>18000^{\circ} \mathrm{C}\end{array}$ & Available \\
\hline Recomp (PNL) & $\begin{array}{l}\text { JHM, graphite } \\
\text { electrodes }\end{array}$ & $\begin{array}{l}\text { Production } \\
\text { JHM, ash vit. }\end{array}$ & $700 \mathrm{ft}^{2}, 15000^{\circ} \mathrm{C}$ & September 1992 \\
\hline Quantum Tech & PHM pyrolyzer & Same & $\begin{array}{l}200 \mathrm{~kW} \\
>1800^{\circ} \mathrm{C}\end{array}$ & Available \\
\hline
\end{tabular}




\begin{tabular}{|l|l|l|l|l||}
\hline Scorpion Mfg. & AHM, shaft & Same & $\begin{array}{l}750 \mathrm{~kW}, \\
>1800^{\circ} \mathrm{C}\end{array}$ & Available \\
\hline Westinghouse & PHM, all types & Shaft furnace & $\begin{array}{l}1.5 \mathrm{MW}, \\
>1800^{\circ} \mathrm{C}\end{array}$ & Available \\
\hline
\end{tabular}

Lectromelt have systems that can be used for these experiments. If EPI/MIT have facilities available, these can also be used. Retech and Lectromelt can operate in both oxidizing and reducing modes; the EPI system is probably limited to reducing conditions. The Bureau of Mines/ASME facility could be used for large pilot-scale tests. Further work on the FWF optimization including TRU testing in lab/bench scale is needed and best conducted at national lab facilities equipped for this purpose, c.g., INEL.

2. HVPM retention in slag: Similar experiments can be performed at the same vendors or national lab facilities using selected HVPMs. 


\section{REFERENCIES}

1. J. L Mayberry, W. J. Quapp, F. Feizollahi, J. C. Del Signore, and J. McFee, Preliminary Systems Design Study Assessment Report,. Vol. II (Main Report), EGG-WTD-9594-2, September 1991.

2. R. Gillins et al., Thermal Technologies for RWMC Wastes, EGG-WTD-9449, January 1991.

3. P. C. Kong, T. L. Eddy, B. D. Raivo, and G. L. Anderson, Mixed Waste Materials Processing via Thermal Processing Technologies, EGG-WTD-10058, January 1992.

4. G. A. Reimann, J. D. Grandy, T. L. Eddy, and G. L. Anderson, Summary of INEL Research on the IEB Waste Form, EGG-WTD-10056, January 1992.

5. R. Geimer et al., An Assessment of Incineration and Melting Treatment Technologies for Application to RWMC Buried Waste, EGG-WTD-10035, February 1992.

6. T. D. Tait, Demonstration Test Assessment of the Slagging Pyrolysis Incinerator for Processing INEL Transuranic Waste, EGG-TF-6192, September 1983.

7. Lectromelt Corp., World Problem Solving for the ElectroThermal Industry, Pittsburgh, PA, February 1991.

8. C. C. Chapman and J. L. McElroy, "Slurry-fed Ceramic Melter-A Broadly Accepted System to Vitrify High-Level Waste," High-Level Radioactive Waste and Spent Fuel Management, 2, 1989.

9. M. P. Schlienger, R. C. Eschenbach, "Latest Developments with Plasma Centrifugal Furnace," 1st INEL Plasma Waste Workshop, Idaho Falls, ID, January 16-17, 1991.

10. R. D. Peterson, A. J. Johnson, S. D. Swanson, Application of Microwave Energy for In-Drum Solidification of Simulated Precipitation Sludge, RFP-4148, UC-70 Nuclear Waste Management, DOE/TIC-4500 (Rev. 73), August 1987.

11. J. Batdorf et al., Selected Furnace Technology Assessments for RWMC Buried Wastes, EGG-WTD10036, February 1992.

12. D. Dalton, E. M. Steverson, G. L. Anderson, Air Pollution Control in Thermal Treatment Systems, EGG-WTD-10038, January 1992.

13. R. S. Richards and J. W. Lacksonen, "Stir-Melter Vitrification of Simulated Radioactive Waste, Fiber Glass Scrap, and Municipal Waste Combustor Fly Ash," 93rd Annual Meeting of the American Chemical Society, Cincinnati OH, April 29-May 2, 1991. 
14. Penberthy Electromelt, Pyro 31, February 22, 1988.

15. R. Preston, "Annals of Expertise," New Yorker Magazine, February 25 and March 4, 1991.

16. International Iton and Steel Institute, The Electric Arc Furnace - 1990, Brussels, 1990.

17. L. Bromberg, D. R. Cohn, C. H. Titus, J. K. Wittle, Waste Detoxification using Transfer Arc and Electron-Beam Driven Plasma Reactors, Workshop on Plasma Applications to Waste Treatment, January 1991.

18. B. A. Detering and J. A. Batdorf, Plasma Treatment of INEL Soil as a Waste Form for Soil Contaminated with Heavy Metals, EGG-WTD-9925, January 1992.

19. A. C. Lewis, Skygas, Beyond Incineration and Landfills, Photo-Electrokinetic Process for Disposal of Solid and Semi-Solid Wastes, Scorpion Mfg. Co., Libby, MT, February 1991.

20. R. M. Horton and J. M. Welch, Preliminary Assessment of Cesium Volatility from Iron-Enriched Basalt Melts, RE-M-81-003, April 1981.

21. J. M. Welch et al., Iron-Enriched Basalt for Containment of Nuclear Wastes, EGG-J-03181, October 1981.

22. J. M. Welch, R. L. Miller, J. E. Flinn, Fuel and Core Storage and Disposal Development: FY-82 Immobilization of Three-Mile Island Core Debris, EGG-FM-6095, October 1982.

23. J. E. Flinn et al., Annual Report on the TRU Waste Form Studies with Special Reference to IronEnriched Basalt: 1980, EGG-FM-5366, June 1981. 
Appendix A

Vendor Directories 


\section{CONTENTS}

A.1 Joule Melters $\ldots \ldots \ldots \ldots \ldots \ldots \ldots \ldots \ldots \ldots \ldots \ldots \ldots \ldots \ldots \ldots \ldots$

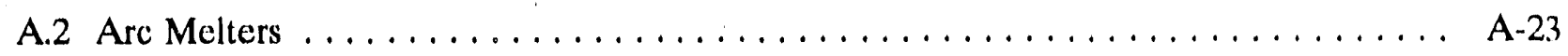

A.3 Plasma Melters $\ldots \ldots \ldots \ldots \ldots \ldots \ldots \ldots \ldots \ldots \ldots \ldots \ldots \ldots \ldots \ldots \ldots$ A-30

A.4 Arc/Plasma Melters $\ldots \ldots \ldots \ldots \ldots \ldots \ldots \ldots \ldots \ldots \ldots \ldots \ldots \ldots \ldots \ldots$

A.5 Additional Vendors Contacted $\ldots \ldots \ldots \ldots \ldots \ldots \ldots \ldots \ldots \ldots \ldots \ldots \ldots \ldots \ldots$ 


\section{A.1 Joule Melters}

\section{VENDOR ASSESSMENT}

\section{Organization assessed: Rocky Flats Plant}

\section{Date: 09/09/91}

Address:

Rocky Flats Plant

\section{Key Personnel:}

Joe Lucerna

Tel. FTS-345-7229, FAX

Main business activity of organization: Pu fabrication.

Size of organization? \$ volume, No. employees: Group has about 1 technical experts.

Length of time in business: years

Brief description of technology (include details on melters, feed handling, product handling, offgas systems, power supplies, controls)
Glass melter X
Arc melter
Plasma melter

Narrative description (use additional sheet if needed)

The Joule heated glass melter as developed by Lucerna uses Inconel 690 electrodes. It is an extremely small volume melter to avoid criticality problems with TRU. Design waste streams are TRU organic sludge and LLW nitrate salts. Operating temperature is about $1150^{\circ} \mathrm{C}$. The unit is designed with multiple electrodes, 6 to a side; power is computer controlled to move from electrode to electrode to create stirring. Lucerna believes that the device is applicable to 16 of the 36 waste streams at RFP. A bench scale unit is $90 \%$ Einished; however, the dimensions (12"w $\times 17^{\mathrm{m}} \mathrm{l} \times 14^{\mathrm{I}} \mathrm{h}$ ) are too large for criticality.

Specific technical issues

Electrodes: (material, cooling, corrosion, life, geometry, number) Inconel 690. 
Environment:

Operating temperature: $1150^{\circ} \mathrm{C}$ max.

Gases used:

Oxidation/reduction, oxidize metals, how?

Freeze lining (skull):

Water cooling. where?

Cold cap:

Off-gas bandling:

Specific wastes:

High vapor pressure metals. How controlled?

Organic destruction: \% organic in feed, destruction where, in plenum, afterburner?

Slag/metal phase separation: Cannot treat metals.

Capacity (MT/h) (production units)

smallest unit:

largest unit:

Power requirements, voltage, amperage, phase? $440 \mathrm{~V} 3 \mathrm{Ph}$. AC min.

Maintainence (special problems, radioactive waste, etc): 
Feed

Sizo restrictions:

Heterogeneity restrictions: Serious.

TRU: OK

Liquids: $\mathrm{OK}$

Sludges: OK

Slurries: OK

Process models:

Do they use? have?

Proprietary___ Source___ Books___

Vitrification studies?, extent?

\section{Applications}

Is technology in use? Low temp borosilicate glass for high level waste.

How many installations? Many experimental (SRL, PNL)

Where?

Can they be seen? Yes

Size of units?

Type and quantity of waste being processed? SRL high level calcine.

Cost of various size installations?

Does it include the following?

Offgas system?

Feed system

Controls

Power supplies

What? 
Is company/organization literature available?

Sales brochures -

Techaical reports - Yes

Test results -

A-8 


\section{VENDOR ASSESSMENT}

Organization assessed: Penberthy Electromelt International, Inc.

Date: $8 / 26 / 91$

Address:

Penberthy Electromelt

631 South 96 th St.

Seattle WA 98108

Tel. see below; FAX see below

Key Personnel:

Larry Penberthy, President

Tel. 206-762-4244, FAX 206-763-9331

Main business activity of organization: Developer and manutacturer of glass melters.

Size of organization? \$ volume, No. employees: Group has about 3 technical experts.

Length of time in business: $20+$ years

Brief description of technology (include details on melters, feed handling, product handling, offgas systems, power supplies, controls)

Glass melter X Arc melter_ Plasma neiter_

Narrative description (use additional sheet if needed)

The Joule heated glass melter as developed by Penberthy uses molybdenum electrodes which permits operation at $1500^{\circ} \mathrm{C}$. The melter has processed 1500 drums of RCRA waste. The unit is at present shut down. Penberthy is seeking partners with money to run experiments.

Specific technical issues

Electrodes: (material, cooling, corrosion, life, geometry, number) Horizontal molybdenum electrodes are used. Oxidation is a problem with these electrodes under some operating conditions. 


\section{Environment:}

Operating temperature: $1500^{\circ} \mathrm{C}$.

Gases used: Air or oxygen injection.

Oxidation/reduction, oxidize metals, how? Oxygen or air injection.

Freeze lining (skull): ?

Water cooling. where? Steel shell.

Cold cap: Possible.

Off-gas handling: Conventional.

\section{Specific wastes:}

High vapor pressure metals. How controlled?

Organic destruction: \% organic in feed, destruction where, in plenum, afterbumer? Pyrolyze and/or oxidize above melt.

Slag/metal phase separation: Almost inevitable.

Capacity (MT/h) (production units)

smallest unit:

largest unit:

Power requirements, voltage, amperage, phase? $440 \mathrm{~V} 3 \mathrm{Ph}$. AC min.

Maintainence (special problems, radioactive waste, etc): 
Feed

Size restrictions: ?

Heterogeneity restrictions: None

TRU: OK

Liquids: $\mathrm{OK}$

Sludges: OK

Slurries: OK

Process models:

Do they use? have?

Proprietary___ Source___ Books___

Vitrification studies?, extent? 1500 drums of RCRA waste processed through experimental melter.

\section{Applications}

Is technology in use? Low temp borosilicate glass for high level waste.

How many installations? Many experimental (SRL, PNL)

Where?

Can they be seen? Yes

Size of units?

Type and quantity of waste being processed? SRL high level calcine.

\section{Cost of various size installations?}

Does it include the following?

Offgas system? No.

Feed system? Yes

Controls? Yes

Power supplies? Yes

What? 
Is company/organization literature available?

Sales brochures - Yes

Technical reports - Yes

Test results - Yes

Brief description of technology (include details on melters, feed handling, product handling, offgas systems, power supplies, controls)
Glass melter
Arc melter $\underline{X}$
Plasma melter

Narrative description (use additional sheet if needed)

This development is being sponsored by the ASME for the development of a municipal ash vitrifier. The design is by Lectromelt and is a three phase AC carbon arc melter of 1-2 MW. The system is sealed so that fugitive gases cannot escape. Volatile metal will be condensed in a cold tube.

Specific technical issues

Electrodes: (material, cooling, corrosion, life, geometry, number)

Carbon electrodes. No temperature limitations; must avoid oxidizing potential above melt.

Environment:

Operating lemperature: No limitations.

Gases used: None

Oxidation/reduction, oxidize metals, how? Oxygen or air injection into melt.

Freeze lining (skull): Possible.

Water woling. where? Steel shell.

Cold cap: Yes, possible problems with bridging and channeling.

Off-gas handling: Conventional.

Specific wastes:

High vapor pressure metals. How controlled? Cold exhaust collector pipe.

Organic destruction: \% organic in feed, destruction where, in plenum, afterburner? Pyrolyze above melt.

Slag/metal phase separation: Almost inevitable if melt is reducing. 
Capacity (MT/h) (production units)

smallest unit: $1 \mathrm{MW}$

largest unit: $80 \mathrm{MW}$

Power requirements, voltage, amperage, phase? $440 \mathrm{~V} 3 \mathrm{Ph}$. AC min. Large units use $13200 \mathrm{~V}$ or more with dedicated transformers.

Maintainence (special problems, radioactive waste, etc):

Feed

Size restrictions: 6 inch cube (?)

Heterogeneity restrictions: ?

TRU: ?

Liquids: ?

Sludges: ?

Slurries: ?

Process models:

Do they use? have?

Proprietary___ Source___ Books___

Vitrification studies?, extent?

Extensive development of pyrometallurgy processes over the years. Melt spinning of basalt to mineral wool.

\section{Applications}

Is technology in use? Three phase.arc in extensive use in extractive metallurgy.

How many installations? Hundreds.

Where? Worldwide

Can they be seen? Yes 
Size of units? Up tis 80 MW.

Type and quantity of waste being processed? Experimental work on municipal waste worldwide.

Cost of various size installations? $1 \mathrm{MW} 2-3 \$ \mathrm{M}$

Does it include the following?

Offgas system? Yes, not nuclear rated.

Feed system Yes

Controls Yes

Power supplies Yes

What?

Is company/organization literature available?

Sales brochures - No, BOM not commercial vendor.

Technical reports - Yes

Test results - Yes 


\section{VENDOR ASSESSMENT}

Organization assessed: Pacific Northwest Laboratory

Date: $7 / 30 / 91$

\section{Address:}

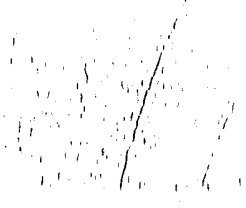

Battelle-PNL

POB 999 MS D7-41

Richland WA 99352

Tel. see below; FAX see below

Key Personnel:

Chris Chapman

Tel. 509-376-6576, FTS 444-6576; FAX 509-376-1867, FTS 444-1867

Main business activity of organization: National Laboratory; main thrust of group is to develop Joule heated glass melters for waste processing.

Size of organization? \$ volume, No. employees: Group has several technical experts.

Length of time in business: 20 years

Brief description of technology (include details on melters, feed handling, product handling, offgas systems, power supplies, controls)

Glass melter X . Arc melter__ Plasma melter_

Narrative description (use additional sheet if needed)

The Joule heated glass melter as developed by PNL uses inconel electroides for low temperature melters $(1100 \mathrm{C})$; somewhat higher temperatures can be achieved by water cooling the inconel electrodes. A municipal ash melter is being developed by Chapman th $t$ uses top entering carbon electrodes; it will operate at $1350 \mathrm{C}$. Solid high melting point metals will settle to the bottom and oxidize slowly. 
Specific technical issues

Electrodes: (material, cooling, corrosion, life, geometry, number)

Internal Inconel 690 elements $\left(1150^{\circ} \mathrm{C}\right)$. Carbon or molybdenum electrodes $\left(1350^{\circ} \mathrm{C}+\right)$.

Temperature and corrosion limitations, especially with carbon and molybdenum electrodes.

Environmeat:

Operating temperature: $1050-1350 \mathrm{C}$.

Gases used: None

Oxidation/reduction, oxidize metals, how? Oxygen or air injection.

Freeze lining (skull): ?

Water cooling. where? Steel shell.

Cold cap: Easy.

Off-gas handling. Conventional.

Specific wastes:

High vaipor pressure metals. How controlled? Low temperature, cold cap.

Organic destruction: \% organic in feed, destruction where, in plenum, afterbumer? Pyrolyze and/or oxidize above melt.

Slag/metal phase separation: Almost inevitable.

Capacity (M/l/h) (production units)

smallest unit:

largest unit:

Power require ments, voltage, amperage, phase? $440 \mathrm{~V} 3 \mathrm{Ph}$. AC min.

Maintainence (special problems, radioactive waste, etc): 
Feed

Size restrictions: 6 inch cube (?)

Heterogeneity restrictions: None

TRU: OK

Liquids: $\mathrm{OK}$

Sludges: OK

Slurries: OK

Process models:

Do they use? have?

Proprietary___ Source__ Books

Vitrification studies?; extent?

\section{Applications}

Is technology in use? Low temp for high level waste.

How many installations? Many experimental (SRL, PNL)

Where?

Car: they be seen? Yes

Size of units?

Type and quantity of waste being processed? SRL high level calcine.

\section{Cost of various size installations?}

Does it include the following?

Offgas system? Yes

Feed system Yes

Controls Yes

Power supplies Yes

What? 
Is company/organization literature available?

Sales brochures - Yes

Technical reports - Yes

Test results - Yes 


\section{VENDOR ASSESSMENT}

Organization assessed: Glasstech, Inc.

Date: $7 / 24 / 91$

Address:

Ampoint Industrial Park

995 Fourth St.

Perrysburg $\mathrm{OH} 43552$

Tel. 419-661-9500

Key Personnel:

Kenneth H. Wetmore, General Counsel and Secretary

Tel. 419-661-9500; FAX 419-661-9366

- Ray S. Richards, Senior Scientist

Tel. 419-536-8828; FAX 419-661-9366

Main business activity of organization: Glass bending and tempering equipment for the automotive and architectural markets. Recent interest in stirred glass melters for waste processing.

Size of organization? \$ volume, No. employees: Several hundred.

Length of time in business: 20 years

Brief description of technology (include details on melters, feed handling, product handling, offgas systems, power supplies, controls)
Glass melter $\mathbf{X}$
Arc melter
Plasma melter

Narrative description (use additional sheet if needed)

Glasstech, in collaboration with Dennis Bickford of SRL, has developed a stirred low temperature glass melter. Inconel 690 is used for both the vessel and the stirrer. Maximum temperature is about $1150^{\circ} \mathrm{C}$. The Joule heating current goes between the stirrer and the vessel. The units are small wity capacities of $110-220 \mathrm{lb} / \mathrm{h}$. They are especially useful for slurries and perhaps sludges. The mechanical problems of large objects hitting the stirrer prevent treatment of pieces larger than 0.5 in. 
Specific technical issues

Electrodes: (material, cooling, corrosion, life, geometry, number) Inconel 690 container and stirrer in smaller units; inconel 690 bar electrodes in' refractory lined larger units.

Environment: Furnace at temperature of $1050 \mathrm{C}$.

Operating temperature: $1050 \mathrm{C}$.

Gases used: Air.

Oxidation/reduction, oxidize metals, how?

Freeze lining (skull): No.

Water cooling. where? Furnace exterior steel shell.

Cold cap: Possible, cold caps may not be the problem in glas melters that they are in shaft furnaces.

Off-gas handling: Cannot supply.

Experimental Facility Description and Availability: WV-2. $50 \mathrm{~kg} / \mathrm{h}$ system in Toledo, $1150^{\circ} \mathrm{C}$ Inconel 690 stirred melter system. Specifically designed cor slurry.

Specific wastes:

High vapor pressure metals. How controlled? Cold cap.

Organic destruction: \% organic in feed, destruction where, in plenum, afterburner? Pyrolysis above glass melt. Might require secondary combustor.

Slag/metal phase separation: Solid metals sink to bottom. Removal required.

Capacity (MT/h) (production units)

smallest unit:

largest unit:

Power requirements, voltage, amperage, phase? $440 \mathrm{~V} 3 \mathrm{Ph}$. AC min. 
Maintainence (special `roblems, radioactive waste, etc):

Feed

Size restrictions: $0.5 \mathrm{in}$.

Heterogeneity restrictions: No Al. Limited metals.

TRU: OK

Liquids: $\mathrm{OK}$

Sludges: Large amounts probably OK.

Slurries: Large amounts probably $O K$.

Process models:

Do they use? have?

. Proprietary___ Source__ Books___

Vitrification studies?, extent?

SRL data available: Denny Bickford

\section{Applications}

Is technology in use? No

How many installations?

Where?

Can they be seen?

Size of units?

Type and quantity of waste being processed?

\section{Cost of various size installations?}

Does it include the following?

Offgas system? No

Feed system No

Controls Yes

Power supplies Yes

What? 
Is company/organization literature available?

Sales brochures - Yes

Technical reports - Yes

Test results - Yes 


\section{A.2 Arc Melters}

\section{VENDOR ASSESSMENT}

Organization assessed: Elkem Technology, Inc.

Date: $7 / 26 / 91$

Address:

Parkwest Office Center

POB 177, Bldg. 2

Pittsburgh PA. 15230

Tel. 412-788-6285; FAX 412-788:1470

Key Personnel:

Jerry Hurt, Pres.

Tel. ; FAX

Frank Fereday, Tech. Mgr. Air Pollution Control

Arner Saeter, Controller

Main business activity of organization: Billet surface inspection equipment; Pollution control; baghouse filters; electric are furnace dust treatment; waste management with tertiary metal recovery; environmental protection; and new metallurgical processes.

Size of organization? \$ volume, No. employees: Norwegian company.

Length of time in business: $20+$ years

Brief description of technology (include details on melters, feed handling, product bandling, offgas systems, power supplies, controls)

Glass melter_ $\quad$ Arc melter $\underline{X} \quad$ Plasma melter_

Narrative description (use additional sheet if needed)

Elkem has been contacted, no information as yet received.

Specific tecinical issues

Electrodes: (material, cooling, corrosion, life, geometry, number)

Carbon. 
Environment:

Operating temperature: No significant limitations.

Gases used: None

Oxidation/reduction, oxidiz: metals, how? Fumace and melt would need to be oxidizing.

Freeze lining (skull): Possible.

Water cooling. where? Furnace exterior steel shell.

Cold cap: Possible.

Off-gas handling: Yes.

Specific wastes:

High vapor pressure metals. How controlled?

. Organic destruction: \% organic in feed, destruction where, in plenum, afterbumer?

Slag/metal phase separation: Slag floats on metal.

Capacity (MT/h) (production units)

smallest unit:

largest unit:

Power requirements, voltage, amperage, phase? $440 \mathrm{~V} 3 \mathrm{Ph}$. AC min.

Maintainence (special problems, radioactive waste, etc): 
Feed

Size restrictions:

Heterogeneity restrictions:

TRU:

Liquids:

Sludges:

Slurries:

Process models:

Do they use? have?

Proprietary___ Source___ Books

Vitrification studies?, extent?

Applications

Is technology in use?

How many installations?

Where?

Can they be seen?

Size of units?

Type and quantity of waste being processed?

Cost of various size installations?

Does it include the following?

Offgas system? Yes

Feed system Yes

Controls Yes

Power supplies Yes

What?

Is company/organization literature available?

Sales brochures - Yes

Technical reports - Yes

Test results - Yes 


\section{VENDOR ASSESSMENT}

Organization assessed: Lectromelt Corporation, Div. Pennsylvania Engineering

Date: $7 / 23 / 91$

Address:

95 32nd St., POB 4023

Pittsburgh PA 15201

Key Personnel:

J. Kevin Cotchen, Director of Technology

Tel. 412-288-6800; FAX 412-288-8339

Dennis L. Hixenbaugh, Vice-Pres and General Mgr.

Tel. see above

- Howard Davis, Director of Technology (retired)

412-429-0367

Main business activity of organization: Lectromelt is a long time supplier of electric arc furnaces for the metallurgical industry. Pyrometallurgical furnaces bear many similarities to waste treatment furnaces.

Size of organization? \$ volume, No. employees:

Length of time in business: 75 years

Brief description of technology (include details on melters, feed handling, product handling, offgas systems, power supplies, controls)
Glass melter
Arc melter $\mathrm{X}$
Plasma melter

Narrative description (use additional sheet if needed)

Arc melting and smelting have generally used 3-phase AC with 3 or more electrodes arranged vertically in a furnace. The electrodes can arc to each other or through the bath, which gives a substantial amount of Joule heating. DC arc furnaces are becoming more popular; DC furnaces use a single electrode arcing to the bath. The return electrode is either metal in the bottom of the hearth or conductive refractories. Arc technology has been used for almost 100 years for the smelting of metal ores. There are no significant temperature limitations except those that are imposed by the refractory vessel for the molten material. This can be overcome by using a freeze 
wall (skull) of the material being melted. The skull is maintained by water cooling the stuell at a rate sufficient for the formation of a solid layer. A $50 \mathrm{~kW}$ single phase AC laboratory unit is available for tests.

\section{Specific technical issues}

Electrodes: (material, cooling, corrosion, life, geometry, number, Graphite, 1,2,3 or more depending on phase and whether DC or AC.

Environment: Refractory lined furnace with external water cooling of outer shell.

Operating temperature: No significant limitations.

Gases used: None needed for arc formation. Gases can be lanced into the melt for redox control.

Oxidation/reduction, oxidize metals, how? Must not be highly oxidizing near electrodes. Melt can be more oxidizing than atmosphere above melt by injecting gas into melt. Stainless steel, etc. will form a separate phase below the slag that is hard to oxidize. HVPM's will oxidize more easily if melt is oxidizing.

- Freeze lining (skull): Possible.

Water cooling. where? Furnace exterior steel shell.

Cold cap: Possible.

Off-gas handling. Baumco Div. of Pennsylvania Engineering could supply.

\section{Specific wastes:}

High vapor pressure metals. How controlled? Cold cap (burden) might recycle high vapor pressure metals back down reactor. Burdens can plug up, however. This needs investigation. An oxidizing melt will keep HVPM's oxidized and in the slag phase instead of vaporizing.

Organic destruction: \% organic in feed, destruction where, in plenum, afterburner? Pyrolization in cold cap (countercurrent flow of hot gas and feed). Secondary destruction of organic gases might be required. Probably no limitations on organic in feed; however, organics will tend to make melt reducing, exacerbating the problem of vaporizing HVPM's (see above). Liquids maybe a problem by evaporating faster than offgas system can handle.

Slag/metal phase separation: Separation possible in melter depending on redox. Separate metal phase might be difficult to oxidize in a reasonable time. 
Capacity $(\mathrm{MT} / \mathrm{h})$ (production units)

$$
\begin{aligned}
& \text { smallest unit: } 1 \mathrm{MW} \\
& \text { largest unit: }>50 \mathrm{MW}
\end{aligned}
$$

Power requirements, voltage, amperage, phase? These are very high powered devices requiring special transformers, power conditioning to avoid noise on the grid, etc.

Maintainence (special problems, radioactive waste, etc):

Might be difficult to seal electrode entry. Large units more difficult than smaller ones. ASME unit at Albany BOM will give some answers.

\section{Feed}

Size restrictions: TBD

Heterogeneity restrictions: Wide.

. TRU: Possible sealing problems in larger furnaces.

Liquids: Probably limited.

Sludges: Large amounts probably OK.

Slurries: Probably somewhat limited.

Process models:

Do they use? have?

Proprietary___ Source___ Books __

\section{Vitrification studies?, extent?}

Extensive experience in melting of ores for ryrometallurgical operations. Slag technology is essentially vitrification technology. Extensive experience in melting basalts for rock wool production. 


\section{Applications}

Is technology in use? Yes, in pyrometallurgy.

How many installations? Hundreds woridwide.

Where? Many in US; Stillwater MT closest.

Can they be seen? Yes

Size of units? $30 \times 100 \mathrm{ft} \times 80 \mathrm{MW}$.

Type and quantity of waste being processed? Copper ore.

Cost: of various size installations?

Does it include the following?

Offgas system? Yes

Feed system Yes

Controls Yes

Power supplies Yes

What?

$2 \mathrm{MNN}$ pilot system would be approximately

Is company/organization literature available?

Sales brochures - Yes

Technical reports - Yes

Test results - Yes 


\section{A.3 Plasma Melters \\ VENDOR ASSESSMENT}

Organization assessed: Browning Engineering

Date: $11 / 27 / 91$

Address:

Key Personnel:

Rob Lalumiere

Tel

FAX 60: 632-4031

Main business activity of organization: Plasma waste processing

Size of organization? \$ volume, No. employees:

Length of time in business:

Brief description of technology (include details on melters, feed handling, product handling, offgas systems, power supplies, controls)
Glass melter
Arc melter
Plasma melter $\mathrm{X}$

Narrative description (use additional sheet if needed)

Torch supplier only. PTI uses the TAFA inductively coupled torch.

Specific technical issues

Electrodes: (material, cooling, corrosion, life, geometry, number, AC/DC)

Environment:

Operating temperature: 
Gases used:

Oxidation/reduction, oxidize metals, how?

Freeze lining (skull):

Water cooling. where?

Cold cap:

Off-gas handling:

Specific wastes:

High vapor pressure metals.

Organic destruction:

Slag/metal phase separation:

Capacity (MT/h) (production units)

smallest unit:

largest unit:

Power requirements, voltage, amperage, phase?

Maintainence (special problems, radioactive waste, etc):

Feed

Size restrictions:

Heterogeneity restrictions:

TRU:

Liquids:

Sludges:

Slurries: 
Process models:

Do they use? have?

Proprietary___ Source___ Books.__

Vitrification studies?, extent?

Applications

Is technology in use?

How many installations?

Where?

Can they be seen?

Size of units?

Type and quantity of waste being processed?

Cost of various size installations?

Does it include the following?

Offgas system?

Feed system

Controls

Power supplies

What else?

Is company/organization literature available?

Sales brochures -

Technical reports -

Test results - 


\section{VENDOR ASSESSMENT}

Organization assessed: Plasma Technology Inc.

Date: $11 / 27 / 91$

Address:

7820 Pan American Freeway NE

Suite 5

Albuquerque NM 87109-4655

Key Personnel:

John Hughes Blanks, President

Tel 505-857-9522

FAX 505-857-9258

- John Vavruska, Consultant

872 Don Cubero Ave.

Santa Fe NM 87501

Tel 505-983-1661 (also FAX)

Main business activity of organization: Plasma waste processing

Size of organization? \$ volume, No. employees:

Length of time in business:

Brief description of technology (include details on melters, feed handling, product handling, offgas systems, power supplies, controls)

$$
\text { Glass melter_ } \quad \therefore \quad \text { Arc melter_ } \quad \text { Plasma melter X }
$$

Narrative description (use additional sheet if needed)

Torch supplier only. PTI uses the TAFA inductively coupled torch. 
Specific technical issues

Electrodes: (material, cooling, corrosion, life, geometry, number, AC/DC)

Environment:

Operating temperature:

Gases used:

Oxidation/reduction, oxidize metals, how?

Freese lining (skull):

Water cooling. where?

Cold cap:

Off-gas handling:

Specific wastes:

High vapor pressure metals.

Organic destruction:

Slag/metal phase separation:

Capacity (MT/h) (production units)

smallest unit:

largest unit:

Power requirements, voltage, amperage, phase? 
Maintainence (special problems, radioactive waste, etc):

Feed

Size restrictions:

Heterogeneity restrictions:

TRU:

Liquids:

Sludges:

Slurries:

Process models:

Do they use? have?

- Proprietary___ Source__ Books__

Vitrification studies?, extent?

\section{Applications}

Is technology in use?

How many installations?

Where?

Can they be seen?

Size of units?

Type and quantity of waste being processed? 
Cost of various size installations?

Does it include the following?

Offgas system?

Feed system

Controls

Power supplies

What else?

Is company/organization literature available?

Sales brochures -

Technical reports -

Test results - 


\section{VENDOR ASSESSMENT}

Organization assessed: Plasma Energy Corp., Subsidiary First Mississippi Corp.

Date: $7 / 25 / 91$

Address:

Umstead Industrial Park

Route 8, Box 114-Z

Raleigh NC 27612

Tel. 919-787-2237

Key Personnel:

S. L. (Bud) Camacho, Chief Scientist, First Mississippi Corp.

Tel. 919-846-4915; FAX 919-846-4839

- Tom Gahagan

Main business activity of organization: Plasma torches and reactors.

Size of organization? \$ volume, No. employees:

Length of time in business: 20 years

Brief description of technology (include details on melters, feed handling, product handling, offgas systems, power supplies, controlls)
Glass melter
Arc melter
Plasma melter $\underline{\mathrm{X}}$

Narrative description (use additional sheet if needed)

PEC has recently found a successful niche in the tundish heating business. Non-transferred torches are used to maintain a set temperature in the tundish that feeds molten steel into continuous casting molds. P.EC has had an interest in developing waste treatment technologies. There is an ongoing project to produce a medical waste treatment system for Kaiser-Permanente'. It appears that PEC's role will be limited to torch supplier. PEC has an extensive sub-pilot laboratory facility; this facility is in need of extensive rebuilding and modernization and will not be available for use until mid-' 92 . Some sort of $100 \mathrm{~kW}$ experimental waste facility exists in Huntsville with PEC involvement. PEC also has a business arrangement with Leybold in the 
production and marketing of plasma melting systems for the reactive and refractory metals businesses. PEC has melted INEL soil in a $400 \mathrm{~kW}$ crucible melter. This unit is now out of service.

Specific technical issues

Electrodes: (material, cooling, corrosion, life, geometry, number) Water cooled copper, transferred or non-transferred arc. Electrodes are being used for ladle and tundish heating in the steel industry.

Environment: Refractory hearth and walls. Pyrolyzer has reducing environment.

Operating temperature: No significant limitations.

Gases used: Air, nitrogen, argon.

Oxidation/reduction, oxidize metals, how? Furnace and melt would need to be oxidizing.

Freeze lining (skull): Possible.

Water cooling. where? Furnace exterior steel shell.

Cold cap: Possible, but might have typical shaft furnace problems of bridging and channeling.

Off-gas handling: Cannot supply.

Specific wastes:

High vapor pressure metals. How controlled? Not controlled.

Organic destruction: \% organic in feed, destruction where, in plenum, afterburser? Pyrolysis above melt. Secondary combustion required.

Slag/metal phase separation: Slag floats on metal.

Capacity (MT/h) (production units)

smallest unit: $400 \mathrm{~kW}$

largest unit: $5 \mathrm{MW}$ (est)

Power requirements, voltage, amperage, phase? $440 \mathrm{~V} 3 \mathrm{Ph}$. AC min. 
Maintainence (special problems, radioactive waste, etc):

Feed: PEC has no designed and operating system so that there is no way to answer the following.

Size restrictions:

Heterogeneity restrictions:

TRU:

Liquids:

Sludges:

Slurries:

Process models:

Do they use? have?

Proprietary____ Source___ Books

Vitrification studies?, extent?

INEL soil melting 1990.

\section{Applications}

Is technology in use? Pilot operations.

How many installations?

Where? Kaiser Permanente operational in ' 92

Can they be seen?

Size of units?

Type and quantity of waste being processed? Medical waste.

Cost of various size installations?

Does it include the following?

Offgas system? No

Feed system No

Controls Yes

Power supplies Yes

What? 
Is company/organization literature available?

Sales brochures - Yes

Technical reports - Yes

Test results - Yes 


\section{VENDOR ASSESSMENT}

Organization assessed: Westinghouse Electric Corporation

Date: $7 / 23 / 91$

Address: Science and Technology Center

1310 Beulah Rd.

Pittsburgh PA 15235

Key Personnel:

- Dr. Shyam Dighe; Manager, Plasma

Dale L. Keairns; Minager, Environmental Programs

Tel. 412-256-1954; FAX 412-256-1222

Dr. Tom Congedo, Senior Scientist, Chemical Process Development

Tel. 412-256-1084; FAX 412-256-1222

R. L. (Bob) Fuller; Manager Marketing, Systems Processing \& Technologies Div.

Tel. 412-256-2426; FAX 412-256-1007

Main business activity of organization: Westinghouse is in many business areas. The ones of interest are environmental restoration and plasma waste processing.

Size of organization? \$ volume, No. employees: Very large

Length of time in business: Long time

Brief description of technology (include details on melters, feed handling, product handling, offgas systems, power supplies, controls) 
Glass melter_ Arc maelter_ $\quad$ Plasma melter X

Narrative description (use additional sheet if needed)

Westinghouse has developed a plasma fired cupola. This a shaft furnace with one or more nontransferred plasma torches at the bottom firing into tuyeres. Waste is loaded into the furnace above the downmoving burden. Coke is fed with the waste. Like all shaft furnaces plugging and channeling are problems. Burdens in shaft furnaces need to be carefully controlled to prevent these problems. This is not practical with a heterogeneous unpredictable waste.

Specific technical issues

Electrodes: (material, cooling, corrosion, life, geometry, number, AC/DC) One or more high power water cooled copper non-transferred gas heaters.

Environment: Hot gas injection into tuyeres of a cupola shaft furnace.

Operating temperature: No important limitations.

Gases used: Air. Others possible.

- Oxidation/reduction, oxidize metals, how? Oxidizing below burden, reducing in and above.

Freeze lining (skull): Not applicable.

Water cooling. where? Shaft turnace exterior steel shell.

Cold cap: Cold burden fed from top.

Off-gas handling: Westinghouse can supply.

\section{Specific wastes:}

High vapor pressure metals. How controlled? Cold cap recycles high vapor pressure metals back down reactor. This needs investigation.

Organic destruction: \% organic in feed, destruction where, in plenum, afterburner? Pyrolization in shaft (countercurrent tlow of hot gas and feed). Recycle of pyrolization gases to hot zone. Problem of redox in shaft causing freezang of melt and shaft blockage.

Slag/metal phase separation: Separation possible in collection crucible.

\section{Capacity (MT/h) (production units)}


smallest unit: $2 \mathrm{MW}$

largest unit: $8-16 \mathrm{MW}$

Power requirements, voltage, amperage, phase?

Maintainence (special problems, radioactive waste, etc):

Full size furnace of several MW will be over $100 \mathrm{ft}$ tall. It may be hard to seal such a large unit.

Feed

Size restrictions: $1 / 2$ shaft diameter.

Heterogeneity restrictions: Wide.

TRU: Large hard to seal furnace.

- Liquids: Probably limited.

Sludges: Large amounts probably $\mathrm{OK}$.

Slurries: Probably somewhat limited.

Process models:

Do they use? have?

Proprietary___ Source___ Books___

Vitrification studies?, extent?

\section{Applications}

Is technology in use? Yes

How many installations? One pilot at Westinghouse

Where?

Can they be seen? Yes

Size of units? 30 in diam, $2 \mathrm{MW}$

Type and quantity of waste being processed? Contaminated soil 


\section{Cost of various size installations?}

Does it include the following?

Offgas system? Yes

Feed system Yes

Controls Yes

Power supplies Yes

What?

$2 \mathrm{MW}$ pilot system would be approximately

Is company/organization literature available?

Sales brochures - Yes

Technical reports - Yes

Test results - Yes 


\section{VENDOR ASSESSMENT}

Organization assessed: Retech, Inc.

Date: $7 / 24 / 91$

Address:

POB 997

100 Henry Station Road

Ukiah CA 95482

Tel. $707-462-6522$

FAX $707-462-4103$

\section{Key Personnel:}

Max Schlienger, Pres.

Tel. 707-462-6522; FAX 707-462-4103

\section{r Dick Eschenbach, VP}

Tel. see above

Main business activity of organization: Retech supplies induction, plasma, and electron beam melting equipment to the refractory and reactive metals industries. A few years ago they decided to apply their expertise to the thermal treatment of waste. They have developed a centrifugal plasma melting unit. A pilot unit is currently installed at the CDIF in Butte and a production unit is installed at Sandoz Chemical in Basel. An ordinary hearth/crucible type melter has also been made to melt compacted simulated Rocky Flats drums.

Size of orge nization? \$ volume, No. employees:

10-12 \$M per year; 100-150 empløyees.

Length of time in business: 30 years

Brief description of technology (include details on melters, feed handling, product handling, offgas systems, power supplies, controls)

Glass melter

Arc melter

Narrative description (use ádditional sheet if needed)

The Plasma Centrifugal Reactor (PCR) is a novel design that permits the use of a bottom drain for molten slag with the need for a stopper. Centrifugal force keeps the moiten slag against the wall of the rotating drum of the furnace until the operator decides to pour. Reducing the RPM 
allows the furnace to drain. Originally the furnace was to operate in an oxidizing mode; however, that presented problems so an afterbumer was added to burn pyrolized organics exiting the furnace. Although the fumace has been operating at the CDIF in Butte for a year, there are still many unanswered questions. Included are beavy metal and TRU processing. Another critical area is the oxidation state of the reactor; is it required to control the oxidation state for optimum containment of heavy metals and TRU and is it possible with the possible heavy and uneven flow of organics.

Much simpler is the hearth/crucible device designed to melt compacted drums. A similar water cooled copper torch is used to heat the work, however, there is no rotation and pouring is accomplished by tilting or opening a plug.

Discussions with Max Schlienger led to the conclusion that for radioactive waste it might be much more practical to use graphite torch technology. Copper torct es were perfected for melting of aerospace and electronic materials in which contamination by air or carbon was catastrophic. No such limitations apply to the treatment of waste since the waste is already contaminated with much of the periodic table. Graphite torches can operate at much higher power levels than copper torches and a failure does not spray water into the melting chamber.

Specific technical issues

Electrodes: (material, cooling, corrosion, life, geometry, number)

Water cooled copper, one or more DC.

Environment: Furnace at temperature of $1650 \mathrm{C}$ or higher.

Operating temperature: No important limitations.

Gases used: Plasma gas can be air, nitrogen, or argon.

Oxidation/reduction, oxidize metals, how? Furnace can be run oxidizing if the rate of addition of organics is limited; however, normal practice is to run reducing in upper chamber and destroy organics in secondary combustor.

Freeze lining (skull): Yes.

Water cooling. where? Furnace exterior steel shell.

Cold cap: Not possible.

Off-gas handling: Cannot supply.

Experimental Facility Availability and Schedule: Small (100 kW) rotary plasma melter available; $100 \mathrm{Kw}$ simple crucible melter (discussed above) also available. Both use $75 \mathrm{~kW}$. (nominal) water cooled copper torch. 


\title{
Specific wastes:
}

High vapor pressure metals. How controlled? This is a problem area.

Organic destruction: \% organic in feed, destruction where, in plenum, afterburner? Partial or complete ryrolization upper chamber; oxdation in lower chamber with afterburner.

Slag/metal phase separation: Separation possible in melter depending on redox.

Capacity (MT/h) (production units)

\author{
smallest unit: $1 \mathrm{MW}$ \\ largest unit: $5 \mathrm{MW}$ (guess)
}

Power requirements, voltage, amperage, phase? $440 \mathrm{~V} 3 \mathrm{Ph}$. AC min.

Maintenance (special problems, radioactive waste, etc):

Rotating seals might be maintenance nightmare for TRU and low level.

Feed

Size restrictions: 6 inch cubed.

Heterogeneity restrictions: Wide.

TRU: Maintenance problem with rotation.

Liquids: Probably limited.

Sludges: Large amounts probably OK.

Slurries: Probably somewhat limited.

Process models:

Do they use? have? .

Proprietary___ Source___ Books 
Vitrification studies?, extent?

\section{Applications}

Is technology in use? Yes

How many installations? Two; pilot at CDIF, production at Basel.

Where?

Can they be seen? Yes

Size of units? $600 \mathrm{~kW}$ and $125 \mathrm{~kW}$.

Type and quantity of waste being processed? Contaminated soil

Cost of various size installations?

Does it include the following?

Offgas system? No

Feed system Yes

Controls Yes

Power supplies Yes

What?

2. MW pilot system would be approximately 5-10 \$M.

Is company/organization literature available?

Sales brochures - Yes

Technical reports - Yes

Test results - Yes 


\section{A.4 Arc/Plasma Melters \\ VENDOR ASSESSMENT}

Organization assessed: Electro-Pyrolysis, Inc.

Date: $7 / 26,91$

Address:

Suite 1118

996 Old Eagle School Road

Wayne PA 19087

Tel. 215-687-9070; FAX 215-964-8570

Key Personnel:

Mr. Christy W. Bell

J. Kenneth Wittle, Chemist

. Tel. ; FAX (see above)

Charlie Titus, Electrical Engineer

Dan Cohn, MTT Fusion Laboratory

Tel. 617-253-5524; FAX 617-253-0700

Ron Parker, Director, MIT Fusion Laboratory

Main business activity of organization: Plasma waste treatment reactors. Development of DC carbon electrode pyrolysis device for waste treatment. Collaboration with MIT fusion laboratory.

Size of organization? \$ volume, No. employees: 5. Group has several technical experts.

Length of time in business: 9 years as EPI

Brief description of technology (include details on melters, feed handling, product handling: offgas systems, power supplies, controls)

Glass melter_ $\quad \therefore \quad \operatorname{Arc}$ melter $\underline{\mathbf{X}} \quad$ Plasma melter $\mathbf{X}$

Narrative description (use additional sheet if needed) 
The Unit appears to be similar to DC single electrode electric furnaces for the steel industry. However, an innovative carbon electrode configuration forces gases through the arc zone pyrolizing organics efficiently. Collaboration with MIT Fusion Laboratory gives them access to theoretical capability. Waste is pyrolyzed in a reactor; waste gases are treated external to the reactor. A combined electron beam/microwave gas treatment device is proposed to destroy toxic pyrolization gases. This appears to be overly complex and expensive. See attached narrative.

Specific technical issues

Electrodes: (material, cooling, corrosion, life, geometry, number)

Single massive carbon/graphite electrode.

Environment:

Operating temperature: No significant limitations.

Gases used: None

Oxidation/reduction, oxidize metals, how? Pyrolytic operation.

Freeze lining (skull): Possible (?)

Water cooling. where? Electrode holder and seals.

Cold cap: Possible depending on materials.

Off-gas handling: Conventional. Wet scrubber and ground level flare or dry scubber if appropriate.

Experimental Facility availability and description: A $500 \mathrm{~kW}$ unit could be operational at MTT 10 wks after funding.

\section{Specific wastes:}

High vapor pressure metals. How controlled? Low gas volume, chiller baffles.

Organic destruction: \% organic in feed, destruction where, in plenum, afterbumer? 0 to $100 \%$ - preferably inorganic solids. Destruction is in furnace.

Slag/metal phase separation: Multilevel liquid phase tapping. Tipping by pouring or solidification in crucible. 
Capacity $(\mathrm{MT} / \mathrm{h})$ (production units)

smallest unit: $100 \mathrm{~kW}$.

largest unit: $10,000 \mathrm{~kW}$

Power requirements, voltage, amperage, phase? $440 \mathrm{~V} 3 \mathrm{Ph}$. AC min. to $34.5 \mathrm{kV} 3$ phase.

Maintainence (special problems, radioactive waste, etc):

Feed

Size restrictions: Design for requirements.

Heterogeneity restrictions: None

TRU: Can be designed.

Liquids: Same.

Sludges: Same.

Slurries: Technically possible, not economical. Electric heat cost.

Process models:

Do they use? have?

Proprietary $X$, Source___, Books__

Vitrification studies?, extent?

Limited.

\section{Applications}

Is technology in use? No.

How many installations? Two experimental

Where?

Can they be seen? No.

Size of units?

Type and quantity of waste being processed? ? 
Model City demonstration $3000 \mathrm{~kW}$ - not in operation.

Development $150 \mathrm{~kW}$ graphite electrode unit - tested.

Cost of various size installations?

Does it include the following?

Offgas system? Yes

Feed system Yes

Controls Yes

Power supplies Yes

What?

Is company/organization literature available?

Sales brochures - ?

Technical reports - Yes

Test results - Yes 


\section{VENDOR ASSESSMENT}

Organization assessed: Scorpion Mfg./Montana Precison Mining

Date: $7 / 26 / 91$

Address:

2301 Hwy 2 South

POB 1568

Libby MT 59923-1568

Tel. 406-293-3771; FAX 406-293-8484

Key Personnel:

A. C. Lewis, Owner Scorpion

Tel. ; FAX (see above)

- Cloyd Snavely, Consultant

Tel. 406-293-3771
Al Luciano, Consultant
Tel. 406-296-3116; FAX 406-296-2844
Dan Smovanek, Sec., Tres., Dir.
Charles Romberg, Pres. MPM
509-624-3291.
Bob Little, Ops. Mgr., MPM
509-326-3443

Main business activity of organization: Arc/Plasma waste treatment reactors.

Size of organization? \$ volume, No. employees: Varies, 1-22

Leagth of time in business: 10 years

Brief description of technology (include details on melters, feed handling, product handling, offgas systems, power supplies, controls)
Glass melter
Arc melter $\underline{X}$
Plasma melter $\mathrm{X}$ 
Narrative description (use additional sheet if needed)

Unit is basically a shaft furnace with three carbon electrodes near the bottom. High organic material is loaded at the top. Hot gas rises through the burden reacting with and driving off pyrolysis gases. Below the electrodes is a pool of water, or steam is injected to drive a water shift reaction with the carbon in the waste. A stirrer is used to maintain porosity and avoid channeling in the burden. Proprietary grafoil seal design is used to hermetically seal the electrodes. Device operates at positive pressure. A secondary plasma unit is used to treat offgases. A graphite electrode is used to heat a coke bed to $1400-1600^{\circ} \mathrm{C}$ which breaks down pyrolysis products and Enishes water shift reaction. Offgas is $\mathrm{Co}$ and $\mathrm{H}_{2}$ which are used for chemical plant or power production.

Specific technical issues

Electrodes: (material, cooling, corrosion, life, geometry, number)

Three Carbon, $120^{\circ}$ angled downward. Proprietary water ccoling system in hermetic seal area. Uses grafoil seals. Two vertical electrodes in secondary unit, one from top, one from bottom.

Environment: Reducing, water shift reaction with pyrolyis products.

Operating temperature: No significant limitations.

Gases used: Water, steam.

Oxidation/reduction, oxidize metals, how? Reducing.

Freeze lining (skull): Not applicable.

Water cooling. where? Furnace exterior steel shell.

Cold cap: Shaft furnace with down moving burden.

Off-gas handling. Yes. Secondary plasma unit packed with coke operating at $1400-1600^{\circ} \mathrm{C}$ to break down pyrolysis products form primary reactor.

Specific wastes:

High vapor pressure metals. How controlled? Not applicable to present unit.

Organic destruction: \% organic in feed, destruction where, in plenum, afterburner? Unit designed for wood chips, municipal waste, etc. Very high organic loading.

Slag/metal phase separation: Very little slag in present unit. 
Capacity (MT/h) (production units)

smallest unit: $750 \mathrm{~kW}, 1-4$ tons per hour.

largest unit: Milan unit 385 tons per day.

Power requirements, voltage, amperage, phase? $440 \mathrm{~V} 3 \mathrm{Ph}$. AC min.

Maintainence (special problems, radioactive waste, etc):

Feed

Size restrictions: $2^{n} \max$.

Heterogeneity restrictions: Low metal, soil in present unit.

TRU: Organics with TRU probably OK. (Cloth, wood, cutting oil, etc)

Liquids: OK

Sludges: OK

Slurries: With low mineral content.

Process models:

Do they use? have? No.

Proprietary___ Source___ Books ___

Vitrification studies?, extent? Small scale. Vitrification modifications have been designed.

\section{Applications}

Is technology in use? Yes

How many installations? One

Where? Milan

Can they be seen? Yes

Size of units? 385 tpd

Type and quantity of waste being processed? 
Cost of various size installations?

Does it include the following?

Offigas system? Yes

Feed system Yes

Controls Yes

Power supplies Yes

What?

Is company/organization literature available?

Sales brochures - Yes

Technical reports - Yes

Test results - Yes 


\section{A.5 Additional Vendors Contacted}

\section{VENDOR ASSESSMENT}

Organization assessed: Quantum Tech

Date: $11 / 27 / 91$

Address:

Key Personnel:

Rajah Kulkarni

Tel 713-941-2823

FAX 713-941-0659

Main business activity of organization: Plasma waste processing

Size of organization? \$ volume, No. employees:

Length of time in business:

Brief description of technology (include details on melters, feed handling, product handling, offgas systems, power supplies, controls)
Glass melter
Arc melter
Plasma melter

Narrative description (use additional sheet if needed)

Specific technical issues

Electrodes: (material, cooling, corrosion, life, geometry, number, AC/DC)

Environment: 
Operating temperature:

Gases used:

Oxidation/reduction, oxidizo metals, how?

Freeze lining (skull):

Water cooling. where?

Cold cap:

Off-gas handling:

Specific wastes:

High vapor pressure metals.

Organic destruction:

m

Slag/metal phase separation:

Capacity (MT//h) (production units)

smallest unit:

largest unit:

Power requirements, voltage, amperage, phase?

Maintainence (special problems, radioactive waste, etc):

Fexd

Size restrictions:

Heterogeneity restrictions: 
TRU:

Liquids:

Sludges:

Slurries:

Process models:

Do they use? have?

Proprietary___ Source___ Books ___

Vitrification studies?, exient?

\section{Applications}

Is technology in use?

How many installations?

Where?

Can they be seen?

Size of units?

Type and quantity of waste being processed?

Cost of various size installations?

Dores it include the following?

Offgas system?

Feed system

Controls

Power supplies

What else?

Is company/organization literature available?

Sales brochures -

Technical reports -

Test results - 


\section{VENDOR ASSESSMENT}

Organization assessed: Bureau of Mines, Albany OR

Date: $8 / 26,91$

Address:

Albany Research Center

1450 Queen S.W.

POB 70

Albany OR 97321

Key Personnel:

Larry Oden

Tel. 503-967-5862; FTS 420-5862

Main business activity of organization: Bureau of Mines Laboratory. Development of melting processes and extractive metallury.

Size of organization? \$ volume, No. employees: Group has about 75 technical experts.

Length of time in business: 60 years 


\section{VENDOR ASSESSMENT}

Organization assessed: Lawrence Livermore National Laboratory

Date: $7 / 30 / 91$

Address:

Livermore CA

Tel. ; FAX

Key Personnel:

Ravindra Upadhye

Tel FTS 543-1299; FAX FTS

- John F. Cooper

Tel. FTS $543-6649$

Main business activity of organization: National Laboratory; main thrust of group is to develop molten salt waste treatment reactor.

Size of organization? \$ volume, No. exployees: Group has about 6 technical experts.

Length of time in business: years

Bitef description of technology (include details on melters, feed handling, product handling, offgas systems, power supplies, controls)
Glass melter...,
Arc melter
Plasma melter

Narrative description (use additional sheet if needed)

The molten salt reactor uses sodium carbonate at $700 \mathrm{C}$ to treat waste. The waste is limited to gases and liquids with a limited ability to handle solids (such as ash and paper). The reactor is in two stages; the first stage is reducing (pyrolyzing) and operates at a low enough temperature to prevent carryover of high vapor pressure Pu compounds to the second oxidizing stage. The second stage can operate at temperatures higher than $700 \mathrm{C}$ if necessary. Organics are oxidized in the second stage. The carbonate can be recycled to remove disolved ash. Recycling involves dissolution into water, chemical treatment and separation. 
Specific technical issues

Electrodes: (material, cooling, corrosion, life, geometry, number)

External nichrome elements.

Environment: Stainless reaction vessels.

Operating temperature: $700-900 \mathrm{C}$.

Gases used: None

Oxidation/reduction, oxidize metals, how? Not possible.

Freeze lining (skull): None.

Water cooling. where? Not required.

Cold cap: None.

Off-gas handling: Conventional.

Specific wastes:

High vapor pressure metals. How controlled? Low temperature.

Organic destruction: \% organic in feed, destruction where, in plenum, afterburner? Pyrolyze in first stage, oxidize in second stage.

Slag/metal phase separation: not applicable.

Capacity (MT/h) (production units)

smallest unit:

largest unit:

Power requirements, voltage, amperage, phase? 440 V 3 Ph. AC min.

Maintaineace (special problems, radioactive waste, etc): 
Feed

Size restrictions: Not designed for solids (?)

Heterogeneity restrictions: None

TRU: OK

Liquids: $\mathrm{OK}$

Sludges: OK

Slurries: OK

Process models:

T) they use? have?

Proprietary___ Source___ Books__

Vitrification studies?, extent?

Does not vitrify.

\section{Applications}

Is technology in use? No

How many installations? 2 experimental

Where? Rockwell (Santa Susana), LLNL

Can they be seen? Yes

Size of units? Rockwell -

Type and quantity of waste being processed?

Cost of various size installations?

Does it isclude the following?

Offgas system? Yes

Feed system Yes

Controls Yes

Power supplies Yes

What? 
Is company/organization literature available?

Sales brochures - Yes

Technical reports - Yes

Test results - Yes 

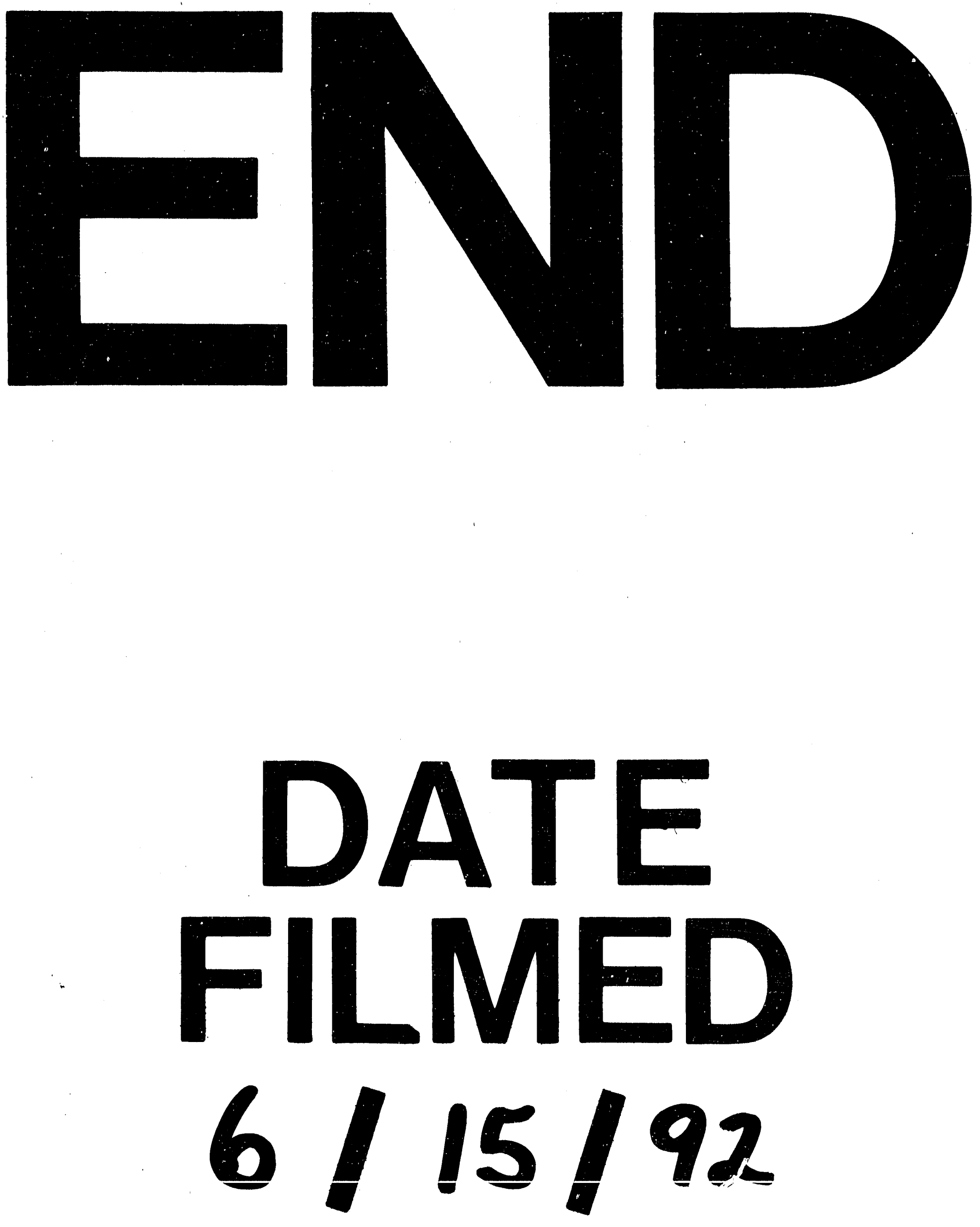
